\title{
$1+3 \%$
}

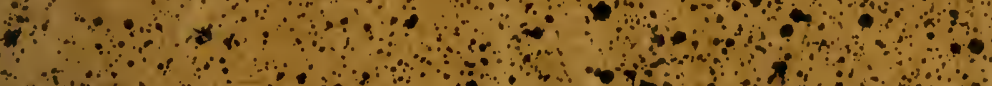
$404+1,1,+1$

(a)

a d

a d

(a) -

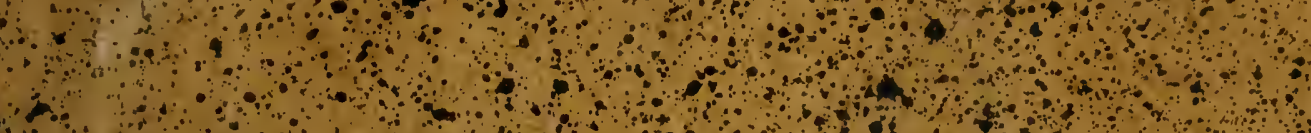

$$
\text { (1) }
$$

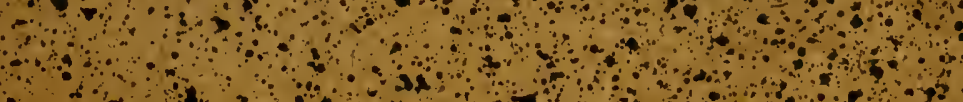$$
\text { (a) }
$$

so (1)

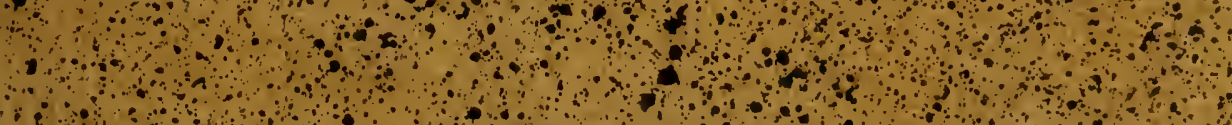

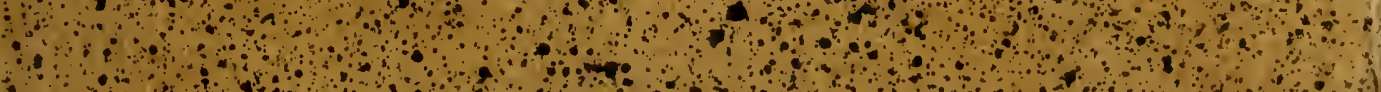
(1) (a)

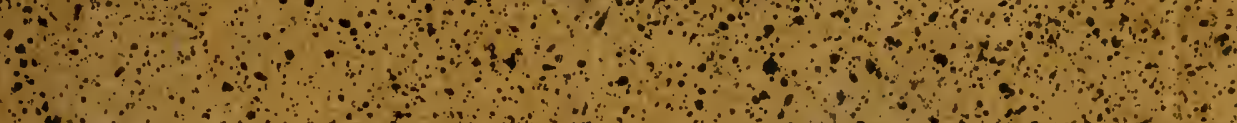
(
$+1$

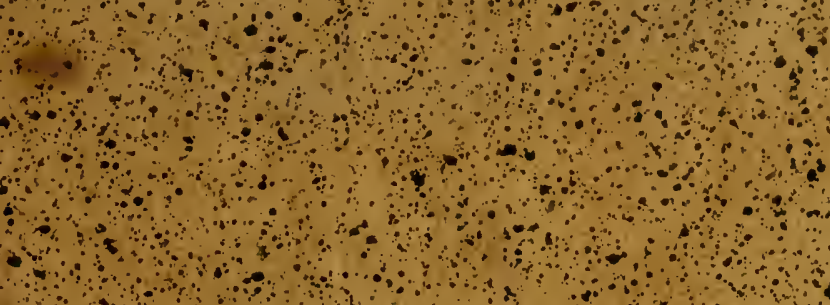




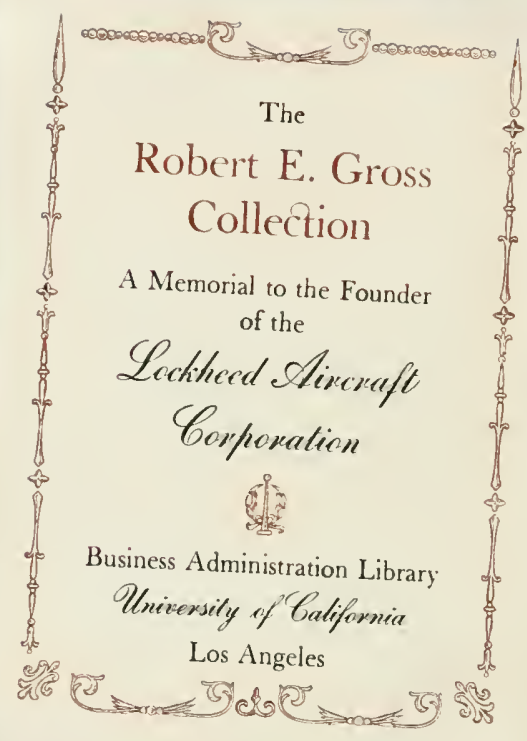




\title{
CARTAS
}

\section{ECONOMICO-POLITICAS}

\author{
SOBRE A AGRICULLTURA,
}

\author{
F COMMERCIO DA BAHIA,
}

\section{PELO}

DESFMBARGADOR JO ÃO RODRIGUES DE BRITO, -

Deputado das Côrtes; e outros.

$$
\begin{gathered}
\text { DADAS A' LUZ } \\
\text { POR }
\end{gathered}
$$

I. A. F. BENEVIDES.

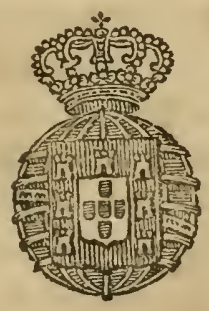

L I S B O A:

NA IMPRENSA NACIONAL. Anno 1821.

Com Licenğa da Commissüo de Censura. 


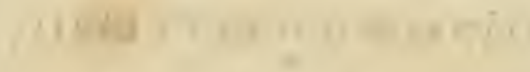

$$
\begin{aligned}
& \text { 1 + } 1,4 \\
& +5+2=5,10
\end{aligned}
$$

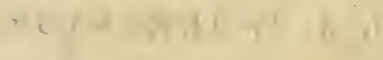

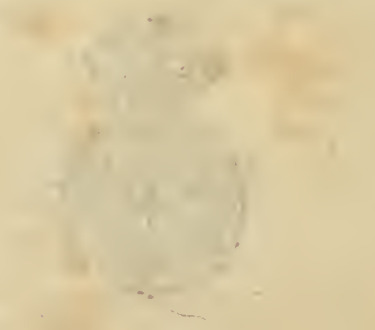

$$
\vdots \ln 11 \div 2=1
$$

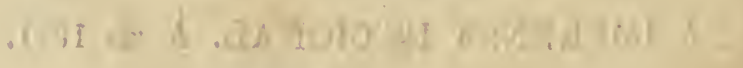

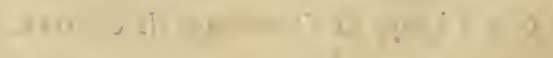




\section{NOÇÄO PRELIMINAR \\ D O E D I T O R.}

T

ENDo subido á Real Presença algumas representaçóes relativas ao estado do Commercio, e Lavoura da Capitania da Bahia, e especialmente contra os exames; e qualificaçóes dos generos que faz a Meza: da Inspecção d'Agricultura, e Commercio daquella Provincia, mandou SuA Magestade, entäo Principe Regente, que informasse o Governador, ouvindo a Camara. Consequentemente dirigio o Governador, que entảo era o Ex. ${ }^{\text {mo }}$ Conde da Ponte, aos Officiaes da Camara o. Officio, que adiante vai copiado, para que dessem a sua resposta em conformidade de cinco quesitos, que formalizou como outros tantos problemas, que offerecia á deliberação do Senado.

Este para melhor desempenhar o que se the incumbia , julgou conveniente ouvir os, pareceres, năo só dos principaes Lavradores, e Commerciantes, mas tambem de algumas pessoas versadas no estudo da Economia Politica, visto que a soluçăo dos quesitos propostos pendia dos conhecimentos desta sciencia.

As Cartas dadas em resposta constituem a presente Collecçăo; cuja importancia, visivel pela mera intuição dos quesitos, se nảo limita ao Brazil, mas he transcendente a Portugal; porque as mesmas causas, que alem retardão os progressos d'Agricultura, e Commercio, os retardăo igualmente neste Reino; 


\section{( (IVi $))$}

sendo outrosim identicos os remedios, que o Leitor achará expêndidos côm tal energia, e clareza, que os principios da sciencia economica até hoje incomprehensiveis á maior parte dos homens, em quanto isolados em puras theorias, se apresentäo agora na mais clara evidencia applicados ao estado actual da nossa Legișlaçăo economica, e da nossa industria , principalmente nas primeiras duas Cartas, quie naquelle tempo ( 1807 ) eráo olhadas na Bahia como o breviario dos Governa-! dores, pela immensidade de abusos, que patenteaváo, descobrindo as causas, e os remedios Com effeito muitos delles foräo emendados, depois que estas Cartas os pintáräo com as devidas cores. Oxalá cheguem ellas tambem agora á noticia dos nossos Deputados! O tempo empregado na sua leitura náo seria perdido, é a Patria teria nuito que agradecer, sé as interesșan-; tés materias nellas indicadas merecessem a attençăa, e discussão do Congresso Nacional, a quem hum dos Authores hoje pertence, como dos mais benemeritos Jurisconsultos Portugnezes, versado na Economia Politica, que professa com profundos conhecimentos práticos.

Lisboa to de Janeiro de I8zr.

I. A. F. Benevides. 


\section{$(\mathrm{V})$}

CARTA DA CAMARA.

Este Senado havendo de informar com o seu parecer sobre cada hum dos artigos insertos no Officio do IIl. ${ }^{\text {mo }}$ e Ex. ${ }^{\text {mo }}$ Sñr. Governador e.Capitáo General, constantes da Copia junta, tem de rogar a V. S. se digne com a brevidade possivel prestar o seu sentimento por escrito, a fim de que em negocio de tanta ponderação sejăo consultadas as conhecidas luzes e talentos de V. S.

Deos guarde a V. S.

Bahia em Camara 20 de Maio de 1807.

Sñr. Desembargador Foăo Rodrigues de Brito.

P. Foăo Homem de Carvalbo.

Francisco Gonçalves Funqueira.

Manoel de Lima Pereira.

Ignacio de Mattos Telles de Menezes.

Luiz da Costa Guimaräes. 


\section{(VIII) )}

As respostas a cada hum destes artigos se devem restringir a hypothesis do estado actual dos Rendimentos Reaes, sem que se exija a organizaçáo de hum systema novo, e imaginario, mas sim o meio mais apropriado ás circunstancias, e capaź de produzir os resultados mais vantajosos á Lavoura, e ao Commercio desta Capital.

Deos guarde a Vv. mercês.

Bahia I2 de Maio de I807.

Conde da Ponte. 


\section{A R T A I.}

Ill. ${ }^{\text {mos }}$ Snr. ${ }^{\text {es }}$ Presid. ${ }^{\text {te }}$, Vereadores, e Proc. ${ }^{\text {or }}$ do Senado.

F

avorecido com a carta de 20 do corrente, pela qual $V V$. SS. se dignão consultar-me subre as causas, que opprimem a Lavoura, e Commercio deste Paiz, e sobre os mais objectos de publico interesse, ponderados no Of-

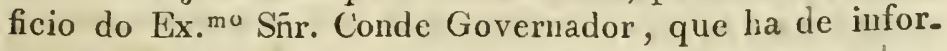
mar sobre elles a S. A. R., sou obrigacio a responider, que a minha penlla he fraca para escrever cousas dignas de subirem a tão respeitavel Presença; mas como assim o ordenão, eu vou expôr ficlmente os meus séntimentos sobre cada hum dos quesitos propostos no mesmo Officio com a maior clareza, que nie permittir a brevidade do tempo, em que devo responder, e com aquella franqueza, que pede a gravidade do negocio, e he devida por todo o Cidadão ás Authoridades constituidas; sentindo sómente que os poucos conhecimentos, que, tenho do Paiz, e da Sciencia economica, me não permittão corres. ponder dignamente ao patriotico zelo, com que VV. SS. se empenbão em colligir observações capazes de auxiliar a marcha do Governo em materia tão importante.

\section{Primeiro quesito.}

"Se reconhecem nesta Cidade alguma causa oppres-

" siva contra a Lavoura? qual seja csta calisa, e o

" meio della se évitar?"

Diversás causas tenho com effeito observado, que, a meu ver, retardão os progressos da Lavoura deste Paiz, 
e muitas dellas faceis de remediar sem offensa do estado actual dos rendimentos Reaes, que se manda respeitar. Só fallarei das principaes. E como, segundo os melhores cconomistas, tudo o que hum Governo póde fazer a bem da Agricultura, se reduz a Liberdades, Facilidades, e InSTRUCçóés, as classificarei conforme esta divisão; fallando primeiro das que nascem da falta de LIBERDADE nos Lavradores, para empregarem setıs braços, e capitaes da maneira que julgão mais conveniente. Em segundo lugar das que vem da falta das Facisidades proprias para auxiliar o exercicio daquella LIPERDADE; como estradas, pontes, e outras obras, e instituięões, que diminuindo as despezas, e obstaculos das communicações e transportes, augmentão em cousequencia os réditos da Lavoura. Em terceiro e ultimo lugar das que resultão da falta das Instrucçóes necessarias aos Lavradores para se aproveitarem daquellas Liberdades, e Facilidades.

\section{Primeira classe.}

- Das causas provenientes da falta de Liberdades.

Para os Lavarares lograrem a plena liberdade, que pede o bem da Lavoura, era preciso que elles tivessem 1. a de caltivar quaesquer generos, que bem lhes parecesse $; 20^{\circ}$ a de construir quaesquer obras, e fabricas que julgassem convenientes para o aproveitamento de seus fructos; $30^{\circ}$ a de os mandar vender em qualquer lugar, por qualquer caminhó, e pelo ministerio de quaesquer pessoas, de que se quizessem servir, sem ónus, ou formalidade alguma; $4 .^{\circ}$ a de preferir quaesquer coinpradores que melhor lhos pagassem; e $5^{\circ}$ finalmente a de os venderem em qualquer tempo, que thes conviesse. Desgraçadamente em nenhum destes artigos a logrrão os Lavradores desta Capitania; porque em quanto ao 


\section{I. $A$ R I 10 O.}

Repetidas Leis, taes como os Alvarás de 25 de Fevereiro de 1688 , e de 27 de Fevereiro de 1701, modernamente instauradas pela Provisão de 28 Abril de 1767, Tobrigão os Lavradores do Reconcavo a plantar quinhentas covas de mandioca por cada escravo de serviço, que empregarem, e aos Negociantes de escravatura a cultivar quanta baste para o gasto dos sens navios. O objecto destas Leis foi não sómente favorecer o Commercio da escravatura, mas tambem segurar a subsistencia daquellas classes de Cidadãos, que despenden maior quantidade de farinhas; prevenindo que não fizrssem encarecer com as suas avnltadas compras, aquelles generos da primeira necessidade, e occasionar por isso alguma fome.

Não duvidamos da pureza das intenções: como porém ella não basta para se alcançar o bem publico, este ultimo objecto não se preencheo, e de facto aquellas Leis directamente contrarias ao Commercio das farinhas, prejudicäo igualmente á Lavoura da cana, e á das farinhas, sem proveito do Commercio da escravatura. A'da cana, porque obrigão o Lavrador a occupar com a mesquinha plantação de mandioca, que se dá em toda a qualidade de terra, os raros e preciosos torrões de massapé, aos quaes a natureza dêo o privilegio de produzirem muito bom assucar, e outros generos de grande valor; vindo por este modo a perder huma parte do rendimento de suas terras, que se fossern: occupadas com as ricas plantas para que são proprias, lhe dariào huma renda mais consideravel, a qual o poria em estado de prover-se de todas as farinhas necessarias, ficaudo-lhe ainda hum sobejo de producto, que poderia einpregar em augmento da mesura lavoura. E prejuricão igualmente a cultura das farinhas, porque forçando os Lavradores de assucar, tabaco, e outros Cidadãos a culti- 
var per si mais do que podem gastar em suas casas, já os proprios Lavradores dellas não achão tão facil sahida ás das suas lavras; e como a sahida he que anima a reproducção, diminue esta proporcionalmente com irreparavel damno dós Lavradores de farinhas, que não podem dar ás suas terras outro destino, por nẫo serem capazes de produzir assuear, algodão, café, etc.

E tudo isto sem proveito dos negociantes da cscravatura; porque estes, pelos principios da divisão do trabalho desenvolvidos por Smith, nẫo podem fazer melhor uso de sua industria, e capitaes, do que empregando-os inteiramente no exercicio da profissão, em que estão exercitados; e a prova lie, que elles preferem antes comprar a farinha pelo preço corrente no morcado, do que distrahirem-se com a cultura della. Pelos mesmos principios prejudicão á Lavoura as outras ordens apparentemente contrarias, que prohibem aos Cidadãos certos ramos de industria, como a criação de gado nas dez legoas da beira mar, pois tanto sofre o Lavrador em ser obrigado a cultivar hum genero que the rende menos, como em deixar de cultivar outro, que lhe renderia mais. Em geral todas as vezes que a Administração publica ze intromette a prescrever aos Cidadãos o emprego, que elles hão de fazer de suas terras, braços e capitaes, ella desarranja o equilibrio, e natural distribuição daquelles agentes da producção das riquezas, cujo uso ninguem póde melhor dirigir que o proprio dono, que he nisso o mais interessado, e que por essa razão faz dielles o objecto das suas meditações. Basta ver a este respeito o sabio João Baptista Say no seu Tratado de economia politica Liv. 1. Cap. 30., (a) Simonde na sua Riqueza com-

(a) Advirta-se que isto foi escripto em 1807 ; e por tanto as citaçôes se referem ás ediçóes, que então existiăo, que a respeito de Say̆, e Simonde são as primeiras.

Nota da Editor: 
mercial Liv. 2. Cap. 3., e Liv. 3. Cap. 1. e 8.; e Young. Arithmetica politica Cap. 12. parter.

Eu só ajuntarei huma reflexão, e he: que provavclimentc daquella prohibição traz origem a falta de pastos, quc se experimenta nas visinhanças desta Cidadc, em que podessem refazer-se os gados destinados para o açougue, os-quaes por essa falta se cortão magros, com grave diminuição no seu pezo en prejuizo do creador, que precisa resarci-lo por hum accrescimo proporcionado no preço da carne; o que augmenta as despezas da lavoura desta vesinhança, sem proveito de ninguem, antes estrago da saude do Povo, e privação da primeira commodidade da vida, a boa carne.

\section{II. $\quad A \quad R \quad T \quad I \quad G \quad O$.}

No segundo artigo não gozão mais liberdade os nos* sos Lavradores, porque thes he prohibida a fundação de fabricas, alambiques, armações de pescar, e engenhos de assucar, sem licenças pendentes de certos requesitos, e formalidades despendiosas. Tudo quanto difficulta o estabelecimento destas fabricas, aggrava a especie de monopolio natural que logrão os senhores das actuaes, precisamente raras por despendiosas, principalmente os engenhos; e deteriora em consequencia a condição já demasiadamente dura dos Lavradores, que os não tem; os quaes muitos annos vêm perder suas canas, por não acharem onde as moer, apesar de pagarem metade do seu producto por esse beneficio, alem da renda da terra, no que sofrem principalmente os que tem servidão, que os obriga a moe-las en engenho determinado; pois os senhores delle preferem naturalmente aos Lavradores desobrigados, com escandalosa lesão dos outros, que não ousão queixar-se, pela absoluta dependencia $\mathrm{cm}$ que estão postos, não vendo proximo ontro engenho em que possão moer suas canas. ; Que differença entre nos- 


\section{(6)}

sas Leis, e as da China! Neste Imperio civilisado ha tantos mil annos, não só he livre a cada hum estabelecer engenhos d'assucar em qualquer parte, mas até andar com engenhocas volantes de terra em terra, offerecendo seus serviços a qualqner, que tem canas a córte. Lntre nós para estabelcce-los na propria casa, cumpre beijolar ao Governador, peitar o Ouvidor, e o Escrivão da Comarca, os quaes sem exorbitantes salarios não vão fazer a indispensavel vestoria, que deve preceder a informação. i Miseros Lavradores, em que mãos estais mettidos! ; Os que só devêrão empunhar a espada , e a penna para proteger vossa liberdade, são os que vo-la tirão, ou vo-la vendem! He certo que alguns senhores dos engenhos estabelecidos, não olhão de bom grado a edificação de outros novos, notando-os de prejudiciaes pelo consumo das lenhas, e madeiras, que fazem encarecer; mas são clamores do interesse particular de cada hum, que deseja afastar a concorrencia dos que lhe vem diminuir suas vantagens; concorrencia porém, que he o germen fecundo da emulação, sem a qual se não deve esperar melhoramento em ramo algum de industria hu. mana. Se as lenhas encarecem, he effeito necessario dos progressos da Lavoura, que alargando o circulo das terras lavradias, deixa ficar os matos mais distantes, donde he forçoso pagar maior despeza de transporte. O augmento do preço deste genero, como o das carnes, he hum symptoma dos progressos da civilisação, e cresce na mesma proporção pelas razões, que explicou Sinith nas suas Indagações sobre a natureza e as causas da riqueza das $N a$ ç̃os Liv. 1. Cap. 11.

\section{A R T I G}

Aquelles mesmos fructos, que os Lavradores tem liberdade de cultivar, e beneficiar com as necessarias preparações, não podem por elles ser vendidos livremente 
na Cidade, Villa, on Lugar, que lhes agrada, nem pela mão de selıs escravos, on agentes quaesquer; mas sofrem constrangimentos neste artigo, formalidades, e encargos.

Sobre isto cumpre notar em primeiro lugar, que similhantes constrangimentos são igualmente contrarios á justiça, e ao interesse publico. Tolber aos Lavradores a liberdade de vender os seus generos no lugar, en que tem maior valur, he o mesmo que roubar-lhes huma porção desse valor; isto he priva-los das riquezas, que elles fizerão nascer com o suor do seu rosto, e emprego dos seus fundos. E esta privação tem infalliveis, e fataes consequencias contra a Lavoura; porque o Lavrador não fez nascer aquelles fructos senão pela esperança de proprio interesse: he lei universal da natureza, que se não póde violar impunemente. Diminuir-lhe o interesse por meio de regulamentos violentos, he diminuir-lhe a vontade, e os meios de cultivar, e por consequencia diminuir a cultura. Todo ónus de qualquer natureza que seja, despeza, oll perda de tempo, que sofre o Lavrador, ou seus agentes, he huma diminuição dos interesses da Lavoura, que tende necessariamente a diminui-la, E por agentes do Lavrador se devem entender não sómente os que vão vender os fructos por conta delle, mas tambem os que thos comprão para os hirem revender com beneficio, porque estes offerecen ao Lavrador hum preço tanto maior, quanto maiores são as vantagens, que esperão obter, e descontão-lhe por consequencia no preço, que lie offerecem, o impor te das despezas, riscos, e encarges, a que está sugeito o trafico daquelle genero. Isto presuposto, permittão VV.SS. que eu lhes diga, que a maior parte dos fructos de nossas lavras, principalmente os da primeira necessidade, estão no caso deste artigo, "rão logrando nunca a devida íberdiade; que aliàs logrão os proḍctos da cultura, e manufacturas estrangeiras, desde que sahem das Alfandegas. 
Os miseraveis Lavradores de farinhas, grãos, e legumes, que pela sua pobreza mereciào ate comiseração, não tem a liberdade de mandar vender seus fructos, onde elles tem melhor sahida, apezar das razões de justiça, e interesse publico ácima ponderacas, e das Leis expressas, que nấo só thes facultâo aquella liberdacie, mas ate franquiza de Direitos taes como a Lei de 4 de Fevereiro de 1773 , e Assento de 24 d'Aluril que sobre ella se tomou; Avisos do 1. de Julho de 1794, e de 17 de Agosto de 1793 ; o Foral desta Capitania, ect. Humas vezes são inhibidos de exporta-los por ordens arbitrarias das respectivas Camaras, pretexlacias com as necessidades do lovo, que dizem, não tem lei; outras vezes constrangidos a traze-los ao celeiro desta Cidade, ainda que ás vezes o consumidor, que os ha de gastar, more lá bem perto do Lavrador, que o produzio, e aindá que elles venhão já ensaccados, e destinados a serem embarcados para a Europa; e huma vez dada a entrada, não tem mais o arbitrio de os levar para fóra, posto que thes venha á noticia haver em outra parte maior preço, e falta do mesmo geilero. Lll $s$ sofrem pois a despeza de huma viagem, ou pelo menos de hum rodeio escusado, o empate do seu capital, e da embarcação, a perça do seu tempo, (que ás vezes só no porto passa de mez para obterem descarga, pois nas tulhasnão cabe nem quanto a Cidade gasta em huma semana) retenção forçada do seu genero para não porlerem aproveitar o justo preço delle, a contribuição que se lhes exige titulo de beneficio da tulha, (de que elles não querião servir-se) aluguel da saccaria, salario da descarga, que se the não consente executar pelos seus escravros; quebras, trocas, e avarias do genero pelas aguas do mar, e chuva; muitas vezes, injurias, preferencias, condemnações, e prizões, de maneira que a instituição do celeiro publico, que seria huma boa facilidade de Commercio admiuistrada sem coacção, sómente 
aos que delle se quizessem aproveitar, se tornou a sua maior difficuldade, excitando geral clamor.

Fóra do celeiro elles tem de nais a mais de sustentar os assaltos dos Meirinhos, e rendeircs, que lhes sat.em ao caes a pedir conta das licenças, fianças, entradas, guias, regimentos, cartas, exames, afcrições illegaes, sellos de pipas, lotações, visitas, e nuil outras fornalidades, que o systema regulamentario tem inventado para surprender coimas á singeleza dos barqueiros, e laviadores rusticos, que em conclusão de seus sofrinentos, e perdas, perdem até a vontade de voltar com outra carregação, e vão espalhar por toda a parte o descorçoamento, desanimando aos que poderião.emprehender iguaes especulações. Sini , jor toda a parte, porque os effeitos do tal systema se estendem mesmo fóra desta Comarca. As lanchas do Cairú, Camamú, etc. são obrigadas a tirar outra licença nesta Cidade para navegar para ella, e regimento de fretes, que lhes não consente levarem por cada sacco mais do que os 20 rs. que levão, os que vem dalli defronte de Itaparica. Extorque-se redizimo do peize dizinado já na Comarca de Porto-Seguro, e nos portos do reconcavo, etc., e contribuição da farinha vendida em Pernambuco. Toda esta massa de cncargos de qualquer natureza que sejão, equivale quanto aos effeitos, a hum roubo que se fizcsse aos miseraveis vivandeiros. Porque tanto importa a farinheiro, por exemplo, que traz hum barco de farinha do valor de cem moedas, que depois de vendido por esse preço os ladrões the roubem dez, como ver-se obrigacio por força dos regulamentos a liquidar noventa unicamente. Em lium e outro caso lhe fica na bolsa a mesma somma, com, esta differença, que no primeiro não desanima, e volta logo a ganhar outras cem moedas, que guarda com mais cautella; e no segundo descorçoa convencido, que não ha cautella contra as insidias dos rendeiros apoiados da força publica. Vendo-se por tanto sem recurso, esmorece, 


\section{(10)}

ax̃o volta mais, anortiza os fundos que possue, deixa scus braços entregues á occiosidade, ou pelo menos dá. Thes outra direcção. Querendo Montesquieu pintar os effeitos do despotismo, descreveo no seu Espirito das Leis Liv. 5. Cap. 13., os Selvagens da Lusiama, que para colherem os fructos cortão a arvore pelo pé. Elles tomão então huma barrigada, mas não esperão mais fructos daquella arvore. As lanchas dos nossos vivandeiros são as arvores de Montesquieu. Os executores dos regulamertos e posturas, podem sim surprender algumas, arruinar seus proprietarios, forçar em fim huma abundancia. passageira ; mas não esperar constantes e regulares provi. mentos, que não podem vir scnào da liberdade do Commercio, e jámais das coacções regulamentarias. Para não restar a menor duvida sobre o gravame, que tacs coacções causão aos farinheiros, basta observar o que se passa actualmente no Celeiro publico.

Os que mandão vender sua farinha por Commissarios, e os que a vendem a bordo, bem como os reven. dedores, tem sido iagora proximamente obrigados a pagar contribuição dobrada; e apesar disso os lancheiros: achão ainda maior interesse em a vender assim, do que esperar para aproveitar o preço corrente, vendendo-a pessoalmente pelo miudo, signal que as penas que elles sofrem pela demora no porto, lhes säo mais onerosas, que as contribuições. E na verdade por modicas que fossem bastava só a fórma, por que os Mestres das embarcações são compelidos a pảga-las para as tornar insuportaveis.

Perante as Justiças ordinarias qualquer Cidadão ainda depois de ouvido, e condemrado segundo a Lei, não he executado sem que primeiro o requeirão para satisfazer a condemnação em vinte e quatro horàs; e ainda então não pagando, sc lhe não penhorão nunca os instrumentos do seu officio, nem impede a viagen dos navios, que tem carregado, pelo favor que as Leis conce- 


\section{(11)}

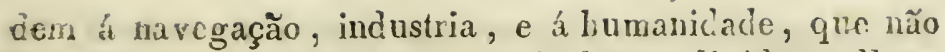
peanitta cxigir-se o pagamento de huma divida, tolhendo ao devedor os meios de adquirir com que a pagte.

Para com os Mestres porém das Sumacas, e barcos dos vivanceiros ha outro Direito. Começão os precedimentos pelo sequestro do léme, e vélas, ainda que o Mestre não seja o culpado, nem devedor, basta que sia sua cmbarcação fosse transportada a farinlia, ou genero qualquer, que dêo materia ao fantastico delicto. E' como hum tal sequestro o priva dos meios de ganhar a vida, fazendo-lhe naior damno, do que experimentaria em pagar o que se the pertende extorquir, elle o exibe incontincute, sem questionar se o deve, nem pedir mais que.o léme, e vélas do seu barco para fugir de hum porto, que tão benigno acolhimento presta aos que lhe vem trazer a abundancia; e se o estado da sua pequena fortuna lhe permitte os meios de substituir outros instrumentos do seu offieio aos apreliendidos, abandona estes, julgando-se mui feliz, se pela escuridade da noite póde escapar ás garras dos rendeiros, e Meirinhos, que elle receia mais, que os perigos do mar. i Tal he a policia do nosso porto, e o favor que nelle experimenta o Commercio!

Da parte de terra não goza elle maior liberdade. O das carnes verdes, que depois das farinhas he o mais importante, está sugeito a iguaes e maiores restricções. O creador dos gados não sómente está privado da líberdade de os mandar vender em qualquer lugar que lhe convem, e pelo ministerio de seus agentes, mas sofre de niais a mais o vexame de ser ubrigado a conduzi-los por huma mesma unica estrada trilhada por muitos milhares de rezes, onde só encontrão huma grande parte do anno para comer poeira, e para beber aguas des rios, em cuja passagem perecem huns afogados por falta de barcas, ou pontes, e no resto do caminho outros sequiosos por falta de poços, tanques, e fontes, que aliàs B 2 


\section{(12)}

facilmente se poterião abrir nas fraldas dos montes, por via de minas, sondando-se com a verruma da terra. E de todas as cabeças que lhe faltão naquelle ermo desde que passa o primeiro registo, he obrigado a dar justificação perante o Superintendente da Feira, carecendo para isso do favor dos Soldados da patrulha, creada para bloquear as boiadas. Sim, Senhores, Soldados para bloquear as boiadas !.... Como os Meirinhos tem medo de hir aos certões fiscalizar a observancia dos regulanentos, por que os Lavradores achão por lá meios de subtrahirse á sua protecção, forão enviados Soldados em seu lugar, para liberalizarem aos conductores dos gados os mesmos beneficios na estrada, que os Meirinhos liberalizão aos vivandeiros no Porto. E assim ficou o Commercio bloqueado por mar, e por terra. O que admira he ser feito hum tal regulamento já depois que o profundo Smith tinha ensinado aos homens, que a natureza do Commercio era bem similhante ás pombas timidas, que fogem ao estrondo das armas, e ás prisões. Já os antigos Ihe divisárão azas pintando com ellas a Mercurio, Deos do Commercio. Vide Encyclopedia, palavra Bourse.

Quando finalmente o conductor chega á Cidade he obrigado a metter nos curraes o resto do gado, que pôde escapar a tantos perigos, e nem então se lhe faculta a liberdade de vender sua carne em o lugar que llie agrada. Porque ainda que a Lei lhe não imponha ontra obrigação mais que a de peza-la, e vende-la nos açougues publicos, sem lhe inhibir nenhum, e esta providencia pareça bastante para a fiscalisação dos Reaes Direitos, e saude publica, com tudo o pobre homem he obrigado a entregar sua fazenda a huma äministração alheia, não the restando mais nem o arbitrio de eleger os açougues, onde lhe convem vender a sua carne, nem os Cortadores que hão de corta-la, nem mesmo, a liberdade de peza-la nas suas balanças, e cobrar o dinheiro pela sua mão. 
Elle a vê ir conduzida (cedo ou tarde) para hum açougue, onde não póde ordinariamente achar hum numero de compradores proporcionado ao das rezes, que se matárão no curral, e he por tanto obrigado a vê-la apodrecer, ou baixa-la ao infimo preço, porque só os que obtem talhos privilegiados, chamados faculdades, pociem vender a qualquer hora: os outros são obrigadics a esperar pela pauta, que assigna esse Senado, para a distribuição dos talhos, e sem esta chegar se não póde pezar a carne; por isso ainda que o preço se abra a 1230 rs., vai logo baixarido a 960 , a 800 até 360 rs. por arroba. Só csta enorme variedade de preços repetida quotidianamente lasta para mostrar que ha vicio radical em hum tal regulamento, pois a irregularidade dos preços he o flagelo da lavoura. Ter-se-ha visto em liuma feira, e n' hum só dia baixar o preço de hum genero a. metarle, e mesmo á quarta parte do seu preço natural, mas repetir-se esta dolorosa scena regularmente quasi todos os dias do anno, isso não tem por certo exemplo na historia do Commercio; estava reservado para os nossos calamitosos tempos, e só podia acontecer não sendo o genero administrado por seu dono.

Por mais barata que o Lavrador offereça a sua carne, não póde jáınais obter os talhes que precisa, porque estes sc repartem não conforme a vontade, ou necessidade que os donos tem de vender, ou o numero das rezes realmente existentes, mas segundo o numero das que vão nas listas, e sc presumem existir nos pastos. vivas, ou mortas, em que toda a vantagem he para os mais ricos Harchantes, que tem de reserva pastagens para cntrete-las, e as sobreditas faculdades para suas vendas privativas.

E como de facto he tambem obrigado a servir-se do ministerio daquelles, a quem esse Senado concedco o privilegio exclusivo de cobrarem o dinheiro alheio contra a vontade de seus donos, a lesão destes he inevi- 
tavel, porque: os taes cobradores nấo aỉcanção aquella faculdade senão medeante alguma summa de dinheiro, que forçosamente ba de saliir do unico objecto, que lhes corre pelas mãos. Dão (quando dão) a sua conta de venda por variados preços; e he natural que apesar das cantellas orcienadas a prevenir fraudes, estas prevaleção sempre contra as providencias da Authoridade Publica, cujos executores, não podem jámais ser tão activos, e vigilantes como os interessados em illudi-la.

Muita porŗ̃ão de carnes, que o povo pagon a quatro patacas, vai carregada a tres. E se não digão-ne ¿donde vem o empenho, com que elles se esforção pa* ra alcançar a faculdade de servirem quasi de graça a homens que não conheccm ?

Se em vez de porfiarcm em praça, ou perante esse Senado; elles porfiassem com os donos da carne, para obterem a preferencia nos seus serviços, a cousa estaria então na ordem: elles não terião ontro meio de obter a Ċesejada preferencia, senão o de servirem bem. Aquelle, que o fizesse com mais vantagem do proprietario, scria o prefcrido; e esta vantagem, ou antes esta justiça feita aos sagrados direitos da propriedade dos creadores do gado, redundaria em augmento deste importante ramo da Lavoura.

Bastaria que esse Senado limitasse os seus cuidados a designar tres, ou quatro açougues espaçosos, onde podessem cortar sua carne todos quantos se apresentassem a vende-la. Os Officiaes da Saude poderião cntão preencher os deveres do seu cargo, achando em poucos pontos reunida a carne toda; e a concorrencia dos compradores faria melhor o seu effeito pela presença da quan. tidade do genero.

O receio da fome dêo occasião aos regulamentos da carne, farinha, e legumes. O caso era grave, não adıira désse cuidado aos Aduninistradores Publicos; mas o tabaco, ainda que exceda muito o consumo da Capitania, 
nem por isso póde obter maior liberdade, e os seus donos são inhibidos de o levar á Europa, que he o lugar onde elle tem maior valor, se primeiro não obtiverena o que se chama approvação; não porque se tema a falta delle, mas em vista de acreditar este genero nacional, que pareceo não poder de outra sorte sustentar na kúropa a concorrencia d'alguins tabacos estrangeiros. Eu porém não posso deixar de considerar esta prohibição tão nociva como as outras á cultura daquelle genero.

Porque $10^{\circ}$ he impossivel fazer-se aqui exactamente aquella approvação em trinta e tantos mil rolos, porque só depois que os tabacos chegão a Lisboa se podem bem qualificar, como reconbece o Alvará de 20 de Junho de $1775 \oint 17$. Em consequencia as injustiças (mesmo involuntarias) vem a ser inevitaveis. ¿Quantas vezes não temos nós visto o tabaco reprovado revestir-se de outra capa, e obter approvação ? ¿ e quantas o approvado chegar podre a Lisboa? Ora as menores injustiças bastão para desanimar ao Lavridor, que beneficiou devidamente o seu genero, vendo baldadas suas fadigas, e perdidas suas despezas pelo temerario arbitrio de hum terceiro, que não contribuio para a producçấo delle, e que talvez obrou com dólo, ou, pelo menos, negligencia nio devido exame. Similhantes approvações, quando dellas pende a liberdade da exportação, tão longe estão de serem uteis ao melhoramento do genero, que pelo contrario a servil dependencia sem recurso, em que os Lavradores do tabaco estão constituidos aos Examinadores, para poderem fazer apparecer os seus genieros no mercado Européo, prejudica á qualidade e commercio delles. Porque como issu depende tão sómente d'approvação, todo o empenho dos Lavradores, e seus subrogados, se dirige a obter o favor dos Examinadores: ganhando este, está conseguido o objecto proposto. E he facil de ver quanta preponderancia devem ter neste particular os Negociantes poderosos sobre os fracos, e Lavradores; e 
quanta aquelles, que fizcrem interessar na negociação os proprios Examinadores, directa ou indirectamente, por sociedade ou consignaçôes dos tabacos á commissão dos Officiaes do pezo, e seus amigos.

Aquella prohibição he fundada nos mesmos principios do antigo systema das corporações, ..e mestranças, instituidas para sustentar o credito das manufacturas, systema hoje completamente refutado, assinı pelos novos c conomistas, como por Smith na obra já citada Liv. 1. Cap. 10, e ultimamente por $M r$. Simonde na sua Riqueza Commercial Liv. 3. Cap. 5., e o Tribuno Say no Tratadio de Economia politica Liv. 1. Cap. 37. e 38. Os quaes todos, e mil outros tem, feito ver, que as impertinencias, dos freguezes, emulação, e concorrencia dos rivaes, juntos á difusão das luzes no paiz, são as verdadeiras causas, que obrigão o productor a aperfeiçoar a qualidade dos generos, e não as prohibições de vende-los sem marca de approvação.

E com, effeito eu não vejo inconveniente attendivel. cm se permititir aos donos do tabaco refugado a liberdade de o-mandarem para a Europa. Se se quer prevenir, que os compradores Européos sejão illudidos pelos nossos vendedores, para isso basta a marca de reprovado, se elles confião mais nella, que nos seus olhos; e se năo confião iporque razão confiaremos nós a ponto de tolher aos Lavradores a faculdade de enviar seus pro: ductos ao inercado, onde tem maior valor? ¿ e onde a incsma faculdade de os levar augmentando a abundancia, deve ser favoravel aos compradores para diminuição de preço ? c ninguem ignora que esta diminuição be hum poderoso motivo para decidir a nosso favor a preferencia dos compradores estrangeiros.

Alguns annos se acha tão desprovido o mercado de Lisboa; que os nossos Commerciantes dão a Lei aos estrangeiros, vendendo-lho por mais do dobro do seu preço natural; e esta lesão os deve afastar màis do que 
afastaria a presença do tabaco refugado qualquer que fosse a sua qualidade, que nunca poderia ser peor que a de muitos approvados, que vão lá sómente scrvir de alimento ao fogo.

E nesses annos succede-nos aqui o contrario! E he verem-se os donos do tabaco refugado percisados a ir receber a lei dos negros na Costa d'Africa, os quaes zombão então dos nossos especuladores; e estes sofrem sem remedio, por não terem a liberdade de procurar outra sahida ao seu tabaco, que então superabunda tanto em Africa, quanto falta na Europa. Esta perda vem toda recahir sobre o pobre Lavrador em diminuição do preço do seu genero, porque o Negociante não lhe promette senão huma bagatela, em attenção á perda que recea.

A Provisão do Real Erario de 18 de Outubro de 1773 , (a) que obriga aos mesmos Negociantes a irem demandar as Ilhas de S. Thomé ou Principe, com grandes despezas, empates, e risco de suias carregações, (que ordinariamente vem de lá infeccionadas) completa a desgraça do Lavrador; porque o Negociante ha de indemnizar-se daquellas despezas, e mortandade de cscravos em accrescimo do preço na venda dos que sobreviverem. De outra sorte abandonaria similhante navegação por ontra, que fosse menos arriscada, do que he aquella com tal ónus, que até expõe a tripulação a ser devorada pelos Barbaros da Costa fronteira de Gabão, a cujo golfo vão muitas vezes arrebatados os navios pela impetuosidade das correntes, sem poderem tomar o canal daquellas Ilhas. A'vista do que, não he para admirar, que os La. vradores do tabaco vivão quasi todos na dependencia dos Negociantes, que lhes assistem com os seus capitaes,

(a) Esta Provisăo foi depois revogada pela Carta Regia de 13 de Abril de 1808 .

Nota do Editor. 
a ponto de se verem obrigados a entregar-lhes o tabaco sem estipulação de preço, nấo se abriudn este ás vezes, senão depois que da kuropa chega a noticia daquelle, por que lá se vendeo.

De todas as restriç̧óes que inbibem aos nossos Lavradores, levarem os seus genems ao lugiar onde tem maior valor, a que talvez mereça maior attençăo do politico philantropico, a mais capaz de tocar sna sensibilin dadc, hc a do Páo-brazil de Porto Seguro. Esta Comarca, não olsstante ter sido a primeira descoberta, jaz ainda na mais deploravel despovoação, e pobreza, não tendo nem carne de açougue, sendo o genero que mais abunta $\mathrm{cm}$ toda a Colonia nascente. Se se franqueasse áquelles. miseraveis Lavradores a liberdade de cortar, e exportar as madeiras de suas mattas, estes córtes deixariăo campos ábertos para pastos e plantações; e nós poderiamos fazer tributarias as Nações industriosas, pela dependencia das nossas tintas, se Thas vend ssemos pelo seu preço natural, e o producto destas vendas animaria a cultura da mesma Comarca, auxiliada pela navegação dos muitos, e grandes rios que a baubăo, principalmente - Tiquitinhonha, cuja navegação se não franquea, por causa dos diamantes, que trazem suas arêas, vindo as sim as mesmas riquezas do paiz occasionar a pobreza dos. seus moradores.

\section{A R $\mathbf{T}, \mathrm{G}^{\circ}$.}

O systema prohibitivo adoptado entre nós não se tem linitado a prohibir aos Lavradores venderem us seus fructos naquelle lugar, onde trn maior valor, e sali:da, e pcló ministerio das pessoas, que merecêrão a sua confiança; mas passou de nais a mais a prohibir certas especies de compradores, cuja coneorreneia devia fazer subir o preço dos fructos em seu benefieio; taes são os Commissarios volantes, atuaveasaciores, revenciedorcs, etc. 


\section{(10)}

E cste he w iarto modo, pelc qual a falta ce liberdade emharaca us prugressus da lavoura.

Consideradas attentamente as cperações dos sobreditos Commissarios, (a) e revendedores, se conhece faciluente que clles não são outra cousa mais, do que pequenos negociantes, que interpoem os seus serviços entre o productor, o o consunidor, com proveito de ambos, па esperança de algुum beneficio, que he a retribuição devida ao seu trabalho, empate, e risco de seus capitaes.

Esta não póde ser onerosa ao Lavrador, nem ao consumador, porque he puramente voluntaria. O Lavrador tem sempre a liberdade de conomzir seus fructos até á jurta do consumidor, e este de lhos comprar immediatamente. Quando pois aquelle prefere antes venre.los por junto no caminho, ou já no porto, he porque acha nisso o seu interesse. He porque lhe convem mais aproveitar o tempo, voltando promptameute á sua lavoura, a vigiar o trabalbo dos sens escravos, e feitores, sempre mais productivo debaixo das vistas de seu dono. E este interesse do Lavrador he o interesse geral mesmo dos consumidores das Cidades; porque a maior prociucção, que resulta delles assistirem nas suas terras, e das vendas favoraveis, difunde a abundancia por toda a parte, c com esta o bom preço, que não póde vir constantcmente senão della.

Os Cominissarios volantes tendem alem disto a con. servar a moralidade dos povos, prevenindo as fraudes, com que os Commissarios domiciliados no paiz costumão lesar os comitentes de Listoa, e Porto, retendo-lhes seus capitaes, recusando-lhes as contas, ou dando-lhas fraudelosas; îraudes que só podem bem precaver os mes-

(a) Já se revogárăo as Itis, que prohibião os Commissarios vo lantes, bem como outras muitas Ordens abusivas; graças aos Autores destas Cartas, que fatenteárāo os dammos, que dellas provinhăo ao Estaưo.

Nota do Editor. 


\section{$(20)$}

mos commitentes, enviando com os generos pessoas de sua confiança, que os vendão, e tmpreguem n'outros o seu producto. As quaes pelo uso destas commissões, (quo são hum tyrocinio de commerciantes) se habilitão para ao depois o virem a ser; de maneira que, em tomando conhecimento do paiz, vem a estabelecer-se com novas casas de Commercio em beneficio dos Lavradores, que achão então maior numero de compraciorcs aos productos de suas lavras, e maior numero de vendedores dos oj. jectos do seu consumo.

Similhantemente os atravessadores, e reveudedores concorrem a preservar a sinceridade dos Lavradores das fraudes, e vexames, a que são expostos quando por si mesmos vendem pelo miudo seus fructos na Cidade, assim da parte dos compradores, como dos rerdeiros, e cxecutores das Posturas, as quaes pela maior parte nก̃o são mais que prohibições, e regulamentos de Comnercio ignorados dos Laviadores, e por consequeucia laços armados á sua sinceridade. ¿Quantas vezes não tem succedido irem elles dar entrada de seus fructos, e quando voltão ao caes não acharem já aquillo, de que fo. rão där a entrada?

Ha alguns generos de industria, em que não se po. dendo desconhecer a necessidade dos atravessadores, se pirmittem, mas só debaixo de certas restricções, e cautellas, adoptadas no intuito de pievenir, que não sejão enganados os Lavradores: tal he o negocio dos gados. Ésse Senalo julgou conveniente não o permittir senc̃o a oito até doze pessoas moradoras desta Cidade, que primeiro se habilitassem com Alvarís de Licença, precelendo fianças, e certas cliuisulas.

Estas clausulas porém, e restricções (com o devido respeito) são as que ústroem todo o effeito do remedio. Os atravessadores não são uteis senão quando o seu numero he ind cfinido sem limitação alguma, porque a propria concorrencia de hums impede os outros de se lock- 
pletarem com ganhos exorbitantes, que só o não são quamlo qualquer outro Cidadão póde concorrer a participar delles, fazendo livremente o nesmo giro; mas restringir o numero dos concorrentes he monopolisar o commercio do genero. Desde o monicnto, em que se limiton o numero dos marchantes, directa ou indirectamente, ficárão os creadores de gados na sua depenciencia; porque chegando á feira, não encontrão mais que os poucos compradores, que esse Senado authoriza a comprar, que de ordinario se reduzem a muito menos do. numero taxado, pela dificuldade de acharem fiachores, que tenhão an mesmo tempo as qualidades, e abonação requcridas com a vontade de sugeitarem-se aos.perigos inlerentes a similhantes fianças, que são nada menos que - de pagarem da Cadeia con sequestro em seus bens antes de ouvidos, e convencidos os figurados alcances de seus fiados. E como se não dispensa esta fiança, nem mesno aos que se offerecem a fazer suas compras com - dinhciro á vista, o numero dos marchantes deverá, sempre ser mui dininuto, ainda suppondo que alguns, delles não sejão meros testas de ferro, on interessados com os outros para encherem o numero prescrito.

Por tanto os pcucos que alcanção a fortuna de poder comprar, e vender, logrão de facto o monopolio deste importante ramo da subsistencia do povo, em damno grave tanto dos creadores, que são então obrigados a vender-lhes os gados por menos, do seu valor por falta de concorrencia de compradores, como dos consumidores da Cidade, que hão de forçosamente comprar a carne mais cara, pela falta de concorrencia de vendedores. E este damno não he o unico, porque de mais a mais aquelle monopolio traz comsigo a natural consequencis da ruindade c.o genero. Se todos os moradores do paiz. lograssem a liberdade, que por direito lhes compete, de irem comprar gados, e traze-Ios a vender nesta Cidade cada vez e quando lhes conviesse, proverião í susten- 
tação delles em pastos proprios, ou alheios, distribuilido-os por toda a parte em pequenas manadas, conforme as oportunidades de cada hun, e assim poderião refa. zer-se, e engordar; o que he impossivel quando elles vem juntos aos milhares; porque não ha pasto algum tão vasto ; que possa fornecer alimento a tantas bocas; nem poucos marchantes, domiciliados todos na Cidade, poderi ter commodidade de repartir suas manadas em inuitos centos de pequenos pastos dos que existem creados para os gyados do trabalho, e ainda quancio a tivessem, lhes não poderia convir isso, pela despeza da multiplicidade de guardas, e pelos descaminhos inevitaveis quando similhantes şeneros sahem da vista de seus donos, sendo por tanto obrigados a cntrete-los nas mattas, c capoeiras, onde a fome, e as plantas veienosas fazem perecer grande parte delles. E se ao menos os marchantes das terras visinhas d'Abrantes, e S. Francisco, que obtem licenças para comprar na feira, tivessem a le comprar todo o gado que lires faz conta, sua concorrencia serviria de freio àos nossos; mas por desgraça para mais se reconcentrar o monopolio, dependem para isso ainda do arbitrio dos terriveis Superintendentes, que á vista de tão despótica authoridade, năo he muito tenhão chegrado a excessos taes, conio o de prenderem aquelles nisiseraveis en hum tronco, barrando-lhes o rosto com a mrassa caustica dás pimentas da terra; e isto á face das Leis que prohibírão os tormentos.

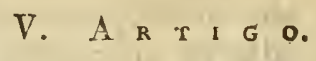

Até em quanto ao tempo se tolhe aos Lavradores, e sens agentes a liberdade de disporem dos fructos da sua lavoura. Os tabacos, pela Provisão de 27 de Outubro de 1785, e outras Ordens posteriores, não podem sahir dos portos do Reconcavo, senão passado o dia 20 de Janei-? ro, por se entender que'antes năo poderião estar devi- 
damente beneficiados. Esta prohibição dá aos que sảhem dos jortos proximos á Cidade sotre os outros a conside. ravel vantagem, de poderem ser primeiro approvados, e embarcados para a Enropa, oide vão aproveitar as primeiras vendas, muito mais vanțajosas em razãc de acharem o mercaco de'Lisboa desprovido por causa da mrsma prehibição. Não sei que proveito nos possa vir dellá. Sei porém que dá aos estrangeiros hum monopolio terr:porario sobre os nossos compatriotas, porque os talacos daquelles se achão na Europa livres da concorrencia dcs nossos até o nucz de Abril de cada anno, chegaudu estes já quando o mercado. se acha provido daquelles; te kta he a primeira pesda que de tal regulamento resulia a lavoura deste continente, perda incalculavel. Segunda: A retenção forçada dos tabacos nos portos do reconcavo até o dia determinado, fazendo que ven\}ão então juntos de huma vez os que aliàs poderião ter vindo successivamente ámcdida, que se fossem apromptando, faz qie cleguem tamben quasi ao mesmo tempo, e não ke pos: sivel descarregaremase todos, e recolherem-se na casa da arrccadação. Ficão por consequencia nos barcos expostos ao Sol, e ús aguas do mar, e chuvas, que lhes deteriorăo a qualidade, vindo por esta maneira a desacredita-los a mesma providencia estabelecida para os acrecitar. A pequenez da casa accrescenta esta desordem a ponto de se demorarem ás vezes as embarcações setenta dias para descarregaren, o que facilmente se podia remediar destinando para esta arrecadação o Trapixe da Barnabé, ou qualquer outro, en que elles coubessem. Terceira: Esta denıora extraordinaria não só priva os oแtros ramos da lavoura do uso destas embarcações para w transporte de seus fructos, mas encarece os fretes atć - quadruplo do seu preço commum; concorrendo para esse augmento o novo risco proveniente da demora, pois ba exemplos de se terem submergido no mesino porto, pelos furacũes, quie nesş estação costumão vir, muitas 


\section{(21)}

embarcações das que esperavão liccnça para a descarga, e concorrendo tambem o serem extraordinariamente procuradas naquella época por causa da accumulação dos tabacos nos portos do reconcavo, occasionada pela prohibição.

O que unicamente modifica os effeitos desta he a fraude, com que alguns illudem a sıa execução, introduzindo antes da época legal tabacos novos com o titulo de velhos. Mas o que o Estado ganha em riqueza, perde em moral por similhantes fraudes, que só aproveitão aos máos Cidadãos, acostumando-os a menos presar as Leis. Seria melhor preveni-las, não fazendo regulamento algum contra a libcrdade e justiça natural.

Em geral pociemos dizer sem exageração, que os nossos Lavradores não tem a liberdade de vender por junto os seus fructos, quando cheyão á Cidade, nem de dia, nem de noite. Elles percisão esperar o prazo nas Posturas decretado para se prover o que se chama vulgarmente povo. Neste como em tantos outros artigos o Lavrador he sacrificado ao pertendido interesse dos habitantes das Cidades, digo, ao pertendido interesse; porque o verdadeiro dos consumidores da Cidade se acha de acordo com o do Lavrador, consistindo ambos na plena liberdade do Commercio, como fez ver com a sua natural energia o citado Simonde, Liv. 2. Cap. 3.

- Se lançarmos os olhos para os outros destrictos da Capitania, o quadro não será menos triste; por toda a parte não se vê senão monopolios, subsidics, taxas, e impostos de toda a casta, estabelecidos sem legitima authoridade, nem conhecimento de S. A. P.; e se algum vai, de fóra, estorvar á aquelles regulos os seus monopólios, concorrendo com a sua industria, hum tiro, ou pelo menos huma denuncia de armas curtas he o meio por que elles se desembaração da sua concorrencia. 


\section{$(25)$}

\section{SEGUNDA CLASSE}

Das causas provenientes da falta de facilidades.

Assim como todos os encargos, que augmentăo as despezas do Conmercio, recahem sobre a Lavcura em diminuiçăo do preço dos generos nas primeiras măos, igualmente pelos mesmos principios todas as obras, e instituiçócs, que diminuem essas despezas facilitarido as communicaçốes mercantís, redundăo em beneficio $\mathrm{d} a$ Lavoura, augmentando o mesmo preço nas ditas primeiras mäos, e por consequencia o producto liquido, e interesses dos Lavradores.

A primeira, com que o Governo de qualquer paiz a deve favorecer, he a construcçăo, e conservaçăo das pontes, e barcas para a passagem dos rios, estradas, é canaes, estivas, etc. para o transporte dos fructos, e objectos do consumo do Lavrador, portos, caes, e dokes para o seu embarque, e desembarque.

Estas obras nos faltáo absolutamente, e estamos reduzidos áquellas facilidades, que a natureza por si mesma nos fornece, ou a industria d'alguns particulares, que mesmo á sua custa las fazem muitas vezes; quando algum privilegio exclusivo os năo impede, como acontece no rio de Joanes, que nảo tem ponte por causa do monopolio concedido a certo Padre para passar os gados a nado, es os homens em jangada. Que. lastima!: Que vergonha!r aquil mesmo nas vizinh hanças desta populosa Cidade ! năo só o Governo falta ao dever de estabelecer barcas, ou pontes, mas oppóe obstaculos ao seu estabelecimento.

Huma grande parte do anno cessáo inteiramente as communicaçóes por terra, nảo só onde os rios atra- 
vessảo os caminhos, mas no proprio centro do Recon-

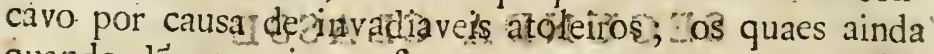
quando dảo transito, o fazem summamente custoso, pe-

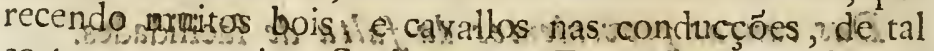
sorte, que muitos Sentiores de Engenhos săo obrigados of empatar suas safrass até o Verâa seguimte , i e faze-las entáo conduzir precisamente na occasiäo, ent que os cavallos bois, es escravos thes sa a mais necessảrios para a collheita, copduc ça Canas irdponde verr gne a Lavoura se acha limitádás terras de beiramár sómente, sendo todo o valor dos fuctos que podetiáo ser produzidos nas do interior, absorvido pelas despezas do transporte.

As estradas da vizinhança da Cidade por estreitas, e ingremes săo imptaticaveisr para os carros, fazendo-se por issojos transportés rás costas de eseravos: muito nais dispendiosamente. Esto accrescimo de despeza encarece o preço dos fructos para o Consumador da Cidade sem proveito do productor do Campo', donde provém desfálece a cultura sémpre mesquinha, por falga de correspomdentes elúcros ; e o mercado na Cidade desprovido náo offeriecier aos Consuniadores se-1 na o poucos fructos, e carbs: sapezar da prodigiosa fer-? tilidade do terreno os produair excetlentes com tigera! cultura.

W O que faz jeste desleixo mais escandaloso he a con-

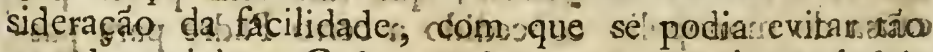
grande prejuizo an Cada estada tem a penas thuma ładeie Ea Ot duas; que a torna impraticavel aos carros!, seriqud se, pederif evitar facilmente, entaminhandora por tonai

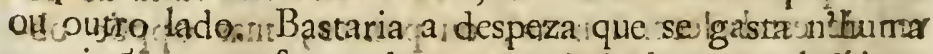
procissão para fazer desapparecer todasuestas ladécasz

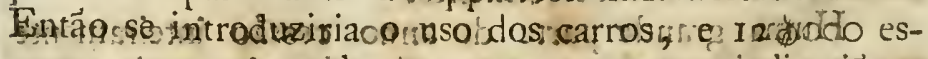

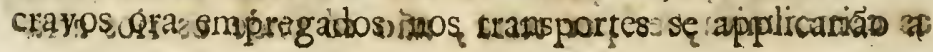


cultivar as roças, desappareceriăo os natos lyumidos, e alagadiços da vizinhança da fidade, e com clles as sezóes, e cutras, molestias y que tios náo deixăo gozar as doçuras do recreio campestré. O Filosofo nảo póde contemplar esta scena com ollos enxutos, Vêr hum povo táo numeroso subinergido na pebreza, podendo com o traballo de hunja semana bem dirigido abrir os mananciaes da abundancia, , e da felicidade !, He huma fortuna em hum tal estado ide cousas ignorar os princịpios da Sciencia econonitca. Póde entáo desculpar-sẹ a traidora opiniáo dos $3 . \mathrm{J}: \mathrm{J}$. J:, dos que sustentá năo se dever permittir to povo abrit os ollos, nem a boca; e lie só em tal estado de luzes, que poden existir semellhantes estradas

Náo he muito que ellas permaneçăo assim 3 quan! do meșmo dentro da Cidade náa ha truma só, râa, por onde hum carro posșa subir dà práa; fazendo-se igualmente á cabeça dos negros o transporte de: todos os:generos que servem ao consuno da Cidade He maior o gasto, que se faz nos frétes dos materiaes empregados na

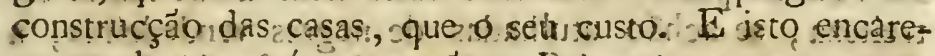

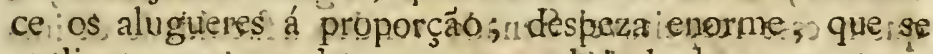
podia poupar a todo este povo, cabrindo tuma rua me nos ingreme, pela qual subissem carros carregados: Bas: taria inclinar a do caminho novo f que verio do caes dourado, duas ou tres braças' mais para a parte do mar, até entrav no Taboh́, pouco a cima dos açougue, é chegando á Baixaldos çapateiros, romper dưs mionadinliąs de casas, que ficảo defronte, para á cohtinuar por detrás day Igreja do Rosario, costeando ol rio das 'Tripas até á Barroquinha. Este mesmo rio; que lie perenne, ase podia encanar: com algumas reprezas yuservindo para navegaçáo, e para delle tirarem os mọradores:regojstos d'agoa para o gasto de suas cozinhas,; jardins. 


\section{(28)}

E para estes fins se podiáo tambem extrahir as agoas do dique, que ora se perdem no mar sem proveito algum, podendo fazellas subir até á maior altura da $\mathrm{Ci}$ dade por meio de bombas de repressăo.

A navegação dos grandes rios da Capitanía tambem nảo se aproveita por insignificantes empecillos, faceis de remover. A do de. S. Francisco está interrompida pela espantosa cachoeira de Paulo Affonso, que sería com effeito impossivel destruir; mas nảo parecia difficil sangrar o rio mais a cima , e separar delle hum braço que tomasse outra direcção. As vantagens seriäo immensas para todos os paizes, que elle banha pelo espaço de mais de quatrocentas legoas, quasi sem valor, por năo haver meio de exportar as suas preciosas producçỏes:

Os caes para o desembarque, e praças para a exposiçảo dos fructos facilităo tambem a sua venda, em beneficio da Lavoura. Sobre este assumpto nằo póde ser desconhecida a esse nobre Senado a falta que temos. As ruas da praia, sem lhes valer nem a sua nimia estreiteza, se achäo atulhadas de negras vendedeiras, a quem esse respeitavel Senado vendeo a faculdade de impedirem o uso publico aos moradores, havendo aliàs na Cidade espaçosas praças, que se podiăo empregar nesse ministerio. Os fructos que năo cabem nas denominadas ruas, são obrigados a ficar a bordo das embarcaçôes, e estas empatadas com risco, e despezas tanto do vivandeiro, que vem a vender, como do Consumador da Cidade, que pertende comprar. Este se vê precisado a fretar hum saveiro para ir ao mar comprar o peixe, a carne, e o mais que em toda a parte se vende nos mercados. $\mathrm{E}$ aquelle paga tambem gurgetas aos catraeiros para the levarem os freguezes, porque de our tra sorte nạâ vè lá compradores estando no mejo do 


\section{(29)}

mar. Que economia! He assim que se facilita o Com= mercio! Tudo póde evitar esse Senado, aproveitando - largo de Santa Barbara para se abrir huma Caldeira que sirva de abrigo ás embarcaçỏes dos vivandeiros, e a quebrada fronteira para a construcção de huma praça de mercado, que, subindo por geios em fórma de amphitheatro até á Cidade alta, sería de igual commodo aos moradores de ambas, segurando ao mesmo tempo a terra solta da montanha, que sem esta obra póde facilmente precipitar-se, sepultando debaixo de si muitas familias, como desgraçadamente năo ha muito vimos succeder. A despeza sería modica ; pois bastariăo poucos palmos de altura ao primeiro socalco, que sustentaria os outros. E nảo faltarăo particulares, que a façảo á sula custa, dando-se-lhes a propriedade das barracas, que levantarem, que he o mesmo que dar-lhes nada, porque nada vale a quebrada no estado em que está, e o valor superveniente do mercado será devido aos cabedacs de quem o construir.

Huma das facilidades do Commercio he a uniformidade dos pezos, e medidas; artigo em que a França deo hum exemplo, e hum plano conforme ao do nosso celebre Mathematico Pedro Nunes, digno de ser imitado por todos os povos, e que o será hum dia, quando os progressos das luzes economicas fizerem desapparecer a rivalidade mercantil d'entre as Naçóes; porque he fundado sobre bases naturaes, e eternas, o pezo d'agoa da chuva, e a medida do Globo terrestre. Entretanto temos a sábia disposiçắo da Ord. L. I. t. I8 $\$ 28$. que, reconhecendo a vantagem d'aquella uniformitade, manda afferir todos os pezos, e medidas, pelo padrăo da Cidade de Lisboa. Esse Sapientissimo Senado, a quem toca a inspecçáo das afferiçóes, e padrỏes, saberá a razão por que náo guarda aquella pro- 
vidente Lei: como tambem: por que obriga alguns $\mathrm{Ci}$ dadăos a terem mais pzzos, e medidas do que precísăo, ao mesmo tempo que prohibz at outros terem os que Ihes convém, sein que primsiro requeiräo, e alcancem licença, que se nảo dá de graça. Que o Senado tenlia sua balança authentica para vêr. o pezó quem tiver duvidas, ou se quizer servir della, he huma facilidade de Comnercio propria a prevenir questóes, e falsidades de pezos, e poupar a muitos a despeza de balanças, escusadas; mas fazer dellas monopolio parece exemplo funesto, he praticar o que deve punir nos outros.

Huma praça de Commercio tambem facilita as communicaçợes, e transaç̧óes mercantís reunindo os Commerciantes na hora assignalada em bum unico ponto, onde o Lavrador apparecendo com as listas dos seus getreros, acha quasi todos os compradores em face huns dos outros, cuja presença os obriga logo a proneytter os justos preços, èm que núo pode facilmente ser enganado estando instruido delles pelas folhas mercantís, que na mesma praça se distribuem. Ella contribue muito para a diffusäo das luzes commérciaes.; e para a moralidade dos Negociantes, que receandó verem-se arguidos publicamente pcrante seus, Collegas da falta de pontual cumprimento das suas obrigaçốes, e quebrar por isso alguma parte do seu crédito, săo mais exactos.em seus pagamentos, e mais circumspectos em șuas promess.s. A falta desta instituiçáa he huma das causas, por que se faz aqui täo pouco apreço das letras.; que ordinariamente se năa pagảo nos seus vencimentos, sendo huma das Cidades mais commèrciantes da Monarchia.

A bos policia do Campo he outra facilidade, com que lium bom Governo: costuma auxiliar a Agricultura; porque a falta della difficula as viagens, e mesmo as 


\section{$\left(3^{I} \cdot\right)$}

reșidencias dos Lavradores nos hugares ermcs, fazendcas thais dispendinsas á proporçăo dó maior risco, e perdas, rque experimenta , assim da parte dos salteadores; como dus mendigos, e vàdios.

Intre nós csimuitos roubos de cavallos tém feito as jornadas do sertăo impraticaveis sem caravana; porque cs passageiros temeni expór-se a ficar apeados em semelliantes desertos. Temos; he verdade, muitas Leis contra ơ ciganos; màs : săo têas de aranha; que só embaraçăo do mosquitos, e săo rotas pelas respas. Oș salteadores tem sempre nesta Cidade hum freguez, a quem, vendem os mellores cavallos por metade do que valem, para terem padrinho quando chegăo a ser prezos; e a proteçảo thes he quasi sempre proficua, graças sì pobreza, e consequente decilidade dos riossos Magistrados:! ?

Não săo menos infaustos á Agricultura os damuinhos e ladróes formigueiros, em cujo numero săo comprehéndidos os mesmos Senhores de Engenhos; que năo, assistem coin of necessario alimento a seus éscravos, ,ponda-os por isso nai precisăo de viverem á i custa das plantaçóes dos viainhos "sobre que nảo vejo a providencia, que reclama as humanidade, $\mathrm{c}$ o interesse bem entendido dos proprios Lavradores; pois "o Alv? de 3.: de Outubro de 1758. só providencêa ao șustento dos escravos prezos, e nem a favor desses se observa senáo por mim, quando os: tenha á minha ordem. Per-

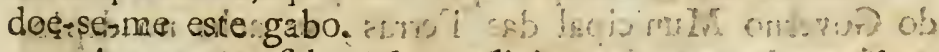
smi A mesma falta / de policia campestre contribue t:kmbem para a despóvoaçăo, gue he reconhecida por: hum dos maiores obstaculos da Lavoura, por ser esta? dé, todas as artes que mais carece do trabalho manual, porquie ise the ná podem applicar as grandes ma

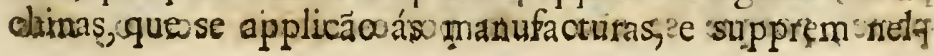




\section{(32)}

las a falta de trabalho humano com o trabalho da natureza. E a falta desta policia contribue para a despovoaçăa, năo só indirectamente difficultando a circulaçăo, e multiplicaçăo das subsistencias, que săo a sua medida, mas até directamente pelos assassinios, que se perpetrăo amiudadas vezes, e que náo será facil prevenir sem se levantarem algumas Companhias de $\mathrm{C}_{\text {aça- }}$ dores de cavallo para auxiliarem as prizóes dos malfeitores, principalmente nas Comarcas de Sergipe e Jacobina. Mas ellas só nảo produzirảo grande effeito sem primeiro se reformar a divisăo dos districtos, erigindo em Villas todas as povoaçőes, que excedem a duzentas familias, e accrescentando a alçada dos Concelhos, e dos Juizes vintenarios, para que năo faltem homens capazes de governar as. Terras, e prender os malfeitores, que năo se animăo a delinquir tăo descaradamente, quando sabem haver perto quem os possa prender, e processar. Nesta Capitanía ha povoaçóes de muitos centos de fogos, que nảo tem podido erigir-se em Villas por causa das opposiçóes dos Officiaes da Cabeça dos Coneelhos, que interessäo nas diligencias dos lugares remotos, e entre tanto nem se tiráo as devassas dos ascassinios; porque de mais a mais se náa elegem para Juizes os melhores Cidadăos, como a Lei recommenda, sem o que se náo deve esperar boa Administraçăo de policia.

Huma das causas por que esta, e os outros ramos do Governo Municipal das Terras, se acha no deploravel estado, que he notorio a todos, consiste na forma por que se fazem as eleiçóes dos Officiaes das Cameras, pois ainda que segundo o espirito das Leis antigas só devảo ser escolhidos os que tiverem por si os votos do povo, de facto este he quem tem nellas hoje a menor parte; porque se náo yota por escrutinio secreto, mas 


\section{( 33 )}

sim perante o Corregedor da Comarca, e seu Escriváo, para Eleitores, os quaes fazem as pautas conforme as insinuaçóes, que se lhes inspiräo, e ainda sem insinuaçóes vem a ficar a eleiçăo no arbitrio de quem apura as pautas; por isso năo admira que o Governo das Cidades, e Villas ande monopolizado em poucas familias privilegiadas, onde năo he facil achar homens capazes para o bom governo dos povos, isto he, sabios, e virtuosos; que os que o náo forem năo devem governar os que o são, pela mesma razáo, que os cégos, e loucos não devem dirigir os que tem vista, e entendimento.

Deveriắo por Lei prescrever-se os gráos de instrucçăo, independencia, e moralidade, que haviăo de ter os pautados, e năo se admittir a votar quem nảo tivesse alguma propriedade, e ao menos o primeiro gráo de instrucçăo, consistente em saber lêr, escrever, e contar, e outro de moralidade, como o de năo estar pronunciado a prizăo, nem penhorado: estes, e semelhantes regulamentos, conduzem indirectamente os Cidadăos a se instruirem, e respeitarem os principios da Justiça natural, cuja praxe he o caminho mais seguro, que eleva as. Naçóes á opulencia; e á felicidade.

A falta de policia urbana tambem contribue para a despovoação. A corrupçáo das garoupas, e outros pescados por mal salgados, apressa a morte a muitos miseraveis, que sáo obrigados a alimentar-se delles, podendo aliàs o peixe fornecer abundante materia ao nosso Commercio pela prodigiosa quantidade, que delle temos nestas costas, principalmente nos baixos dos Abrolhos, se ahi perto se fundasse huma feitoria perita na arte de salgar, e imprensar o peixe, para servir de exemplo, c instrucçắo aos moradores daquellas vizinhanças.

Mas he tal o nosso atrazamento, que nem mora. 


\section{( 34 )}

dores temos ainda, que occupassem aquella rica porçăo da costa do Brazil, parte da qual existe ainda na primitiva, patente ao primeiro occupante.

Qualquer Nação estrangeira, que se lembrar de vir estabelecer-se nella, o pode fazer francamente sem ser sentida, e penetrar dalli em Minas, a surprender-nos de repente. Ditoso paiz, ditosa gente, que dorme com as portas abertas! Meia duzia de vintenas de pescadores estabelecidos naquellas praias, precavendo hum perigo táo evidente, poderiăo ao mesmo tempo fazer cessar a importaçáo do bacalháo, e abrir a communicaçăo directa desta Capitanía com as do Sul, de cuja uniăo pende a prosperidade, e segurança deste Estado.

O mesmo que disse das garoupas, digo das carnes do sertăo. A sua má qualidade, por falta de conveniente preparaçáa, contribue muito para a grande mortandade, que se experimenta nas carregaçổes dos negros da costa d'Africa, e para as molestias, que atacando primeiro os escravos passăo delles a infectar-nos. Os pantanos, e matas encharcadas em roda da Cidade ajudáo tambem a corromper o ár. A situaçăo do cemiterio da parte da viraçáo, o descuido de enterrar prompta, e profundamente os cadaveres, que para alli se lançáo, a pratica de sepultar outros nas Igrcjas, o pouco aceio das escuras ruas da praia, miserias do hospital, c cadeia, tudo concorre para o mesmo fim, publicando que a policia da Cidade está no mesmo estado que a do Campo.

Eu năo fallarei das arqueaçóes dos Navios empregados no trato dos negros, pelas quaes as Leis procurárăo prevenir a cruel tade de trazerem maior número de escravos do que nelles podiáo accommodar-se. Sabe-se que he méra formalidade, para se vencerem os salarios da diligencia, como tantas outras cautélas de 


\section{(35)}

velha, e nova invençăo, que se reduzem a dinheiro extorquido por esta, ou aquella fórma. Os traficantes de carne humana trazem quantos querem. Se a arqueaçáo feita na Bahia thes năo agrada, pedem outra em Benguela, ou em Angola, que he sempre mais apertada para os miseros captivos.

Ainda outro dia entrou, vinda de Angola, a Corveta Sáo Joaquim Augusto com 216 mortos na viagem, fóra os que fallecêrảo depois da entrada; (factos estes que assás justificáo o nosso Mestre J. B. Say, quando no L. I, Cap. 28 compára estas viagens á do Averno, que conduz aos Infernos). Toda a attençắo do Governo se tem fixado nos Capellăes dos Navios, em favor dos quaes temos muitas providencias; nenhuma porém vejo efficaz em favor da saude dos miseraveis negros.

Se em lugar destes nós attrahissemos os Chinas, e Indios orientaes, como já fizemos em outro tempo, e fazem actualmente os Inglezes, povoando com elles a sua Colonia de Pulpinan, ganhariamos náo só braços laboriosos, mas activos, industriosos, e peritos na prática das artes, e Agricultura. A seu exemplo diminuiria a vadiaçẳo dos nossos, a qual equivale á despovoaçáa; porque o mesmo he năo ter homens, que têlos ociosos. Em ambos os casos cessa igualmente o trabalho, de que a Lavoura carece para multiplicar os seus productos.

E que diremos dos votos monasticos, que tåo poderosa influencia exercem, fomentando a ociosidade, e despovoaçăa?

O de castidade (a náo se entender da conjugal) he directamente contrario á propagação, e ainda mais á procrcação da prole. O da pobreza directamente contrario à riqueza, e por consequencia tambern oppos- 
to á povoaçăo, que se năo mantem sem que tire d'aquella a sua subsistencia. Prometter ser pobre he dizer que quer ser sustentado pelo trabalho dos outros, como os zangăos nas colmeias; e náo duvidemos que ao menos neste sentido os Monges guardem este voto mais pontualmente que o primeiro: façamos-lhes esta justiça. $O$ de obediencia he directamente contrario aos principios de Direito público, e ordem social, que só prescreve á obediencia dos Cidadáos á Lei, e seus orgăos, que sắo as Authoridades constituidas para a fazer applicar, e executar.

O de clausura, e solidáo, directamente contrario á sociedade', e liberdade. Juntai a tudo isto a perpetuidade dos mesmos votos, que por si só era capaz de fazer enjoar e detestar os proprios prazeres, quanto mais a prizăo, e escravidăo: e sobre tuło reflecti na barbaridade de apertar estes laços nos tenros annos, cm que a falta de experiencia das vellacarias humanas năo permitte á juventude desconfiar dos artificiosos embustes, com que a illudem, para a fazer renunciar aos seus mais apreciaveis direitos, a liberdade, e a propriedade: tudo a fim de accumular a riqueza paterna n'hum unico filho, e lisongear assim a vaidade da familia com o lustre de hum luxo corruptor nutrido com as lagrimas de seus irmắos. O Filosofo pasma; nem póde comprehender como hum ente, que se diz racional, possa obrar de hum modo tăo contrario á sua nature$\mathrm{za}$, á sua felicidade. Mas deixadas estereis lamentaçóes, vamos ao que importa, que he o remedio da bem conhecida enfermidade. Ordinariamente the ouço applicar o da suppressáo dos Mosteiros, que he o que se lhe applicou em França, c grande parte da Europa. Eu porém nảo subscrevo a destruiçóes de xofre, alheias da marcha da natureza, que sempre caminla gradual- 


\section{( 37 )}

mente. O Lavrador habil tira partido de todo o terreno, de todas as arvores, enxertando-as, ou servindo-se de sua madeira para os diversos usos da vida. Assim eu enxertaria os Mosteiros em bellas Casas d'educaçäo; instrucçăo, e occupaçăo, onde os vadios, e viciosos de hum e de outro sexo achassem a necessaria correcçăo de seus costumes, e adquirissem os conhecimentos necessarios para se tornarem uteis a si, e á Patria, habituando-se ao trabalho; $\mathrm{cm}$ Casas, onde os verdadeiros pobres, e enfermos, achassem allivio, os orfăos educaçăo, os ignorantes instrucçăo, os Filosofos tranquillo retiro para poderem entregar toda a sua alma ás serias meditaçóes da natureza livres dos cuidados do governo domestico, etc.

A vadiaçăo entre nós tem excedido todos os limites, porque ella he favorecida por muitas outras causas além das mencionadas instituiçóes. 'Taes săo: I. ${ }^{3}$ A geral opiniăo, que inspira nos moradores o gosto de possuirem escravos de mero luxo; opiniăo, que só poderá tomar outra direcçảo por meio da instrucçăa, e educaçăo publica, dirigida pelos principios da să politica, que fação formar aos Cidadãos idéas mais justas d'aquillo, em que verdadeiramente consiste a decencia, e dignidade do homem, inseparaveis do bem publico. 2. ${ }^{2}$ A preoccupaçắo nacional, que exclue dos empregos todo aquelle que por si, seus pais, ou avós, tiver exercido artes mechanicas, isto he, que tiver contribuido com o seu trabalho para a multiplicação das riquezas. Hum Escrivăo da mais insignificante Camera năo póde encartar-se na propriedade de seu cfficio, sem provar verdadeira, ou falsamente, a perpetua inacçăo de seus braços, e dos de seus pais, e avós. De sorte que os netos de Pedro Grande, Imperador da Rusșia, nảo poderiäo entre nós conseguir os cargos de Es: 


\section{( $\left.3^{8}\right)$}

crivăes; por ter aquelle Heróe manchado suas máos quando no Texel pegou na enxó , e no machado. $3 .^{\circ}$ A multiplicidade dos dias santos, tắo nocivos pela interrupçăo do trabalho, como pelo abuso, que delles faz o jornaleiro, arruinando na taverna ao mesmo tempo sua sáude, e o seu pequeno capital.

A té os prazcres do pobre excităo os gemidos do Filosofo!... Triste humanidade !...

t $4{ }^{2}{ }^{2}$ A mendicidade, que principia a grassar, sendo aliàs mui facil neste paiz atalhar-lhe os progressos pela benignidade do clima, e immensidade dos fructós, que a' terra produz espontaneamente. Em tal paiz nảo hia pobrés senáo voluntarios. $5 .^{3} \mathrm{~A}$ fórma do recrutamento forçado, que afugenta do exercicio de seus trabalhos os mancebos laboriosos na época mais importante da vida, a da instrucçảo, e formaçăo do espirito no habito do trabalho industrioso, como bem observou Simonde no Liv. 2:" Cap. 4 .

Se se melhorasse a sorte dos nossos defensores, os achariamos voluntarios, e por tanto mais dispostos ao desempenho de suas arriscadas funçóes. Parecia de razáo que, logrando os outrus Cidadăos a liberdade de convencionar o preço do seu trabalho, devêra tambem - Soldado ter ao menos hum soldo proporcionado aos outros serviços. Quem o achasse excessivo, que o aproveitasse sentando praça.

Em Minas, Paraiba, etc. năo faltảo Soldados vofintarios, ainda que o. soldo năo passe de $150 \mathrm{rs}$. Mais do que isto gasta o Estado nesta Capitanía ; mas perde-se a maior parte nos canaes corruptos do fornecimento dos generos; que o Soldado aproveitaria, se recebesse tudo a dinheiro; mas póe-se-lhe o labéo de mal governado, para com este pretexto se the reter a maior parte do'seu'soldo, que alfim se lhe entrega (se se en- 


\section{(39)}

trega) em generos, que the ficåo por mais do dobro do que valem.

6. ${ }^{3}$ A perpetuidade da eșcravidảo, cuja consideração basta para abater o espirito dos escravos, e lança-los em huma inercia fatal. Se estes desgraçados descubrissem hum termo ao seu triste estado, e pudessem, ainda antes delle, remir-se do captiveiro mediante o justo preço adquirido por serviços relevantes, ou por assiduo trabalho nos dias, que lhes săo dados para o descanço, a conşoladora esperança desta felicidade animarił suas actividades. $O$ Estado ganhando hum consideravel accrescimo de trabalho, e industria, veria ir diminuindo o numero d'aquelles infelizes á medida que fossem recuperando suas liberdades convertidos em homens livres, tanto mais uteis, quanto maior he o interesse que tem na ordem social, e o gráo de intelligencia, que se adquire com a pratica da livre administraçắo da propria pessoa, e bens. $\mathrm{O}$ trabalho só he ricamente productivo, onde quem trabalha colle os fructos. 7." A reclusăo do sexo feminino, a quem os costumes deste paiz tem reduzido aos exercicios domesticos do interior da casa, os quacs năo bastando para occupar hum táo grande numero de braços, fica por conseguinte aquella bella metade da nossa povoaçãa destituida de meios de subsistencia, e a cargo dos varôes, que por isso evitäo os matrimonios. Neste particular a introducçăo dos costumes das Naçóes mais civilizadas da Europa, onde o bello sexo se occupa em vender nas lojas, e no exercicio de todas as artes, que nảo exigem grandes forças, nảo só duplicaria a somma das riquezas annualmente produzidas pelo trabalho humano, mas tambem a povoaçăo; e eu ouso crer que as suas virtudes năo perderiăo nada na livre communicaçăo, e trato civil doshomens; antes a maior inde. 


\section{(40)}

pendencia, em que ficariáo a respeito delles, as preservaria dos perigos, a que expóe a necessidade. Além disto o habito do trabalho activo thes daria huma constituiçảo mais vigorosa, e animada; pois vejo a maior parte das senhoras definhar em molestias nervosas, procedidas da inacçăo, e enjôo, em que vivem. Sería conveniente auxiliar a communicação das familias, estabelecendo hum passeio publico com as commodidades competentes para attrahir o concurso dos moradores a verem-se, e fallarem-se. As gelosías tambem obstăo á civilisaçáo, escondendo o bello sexo ao masculino, para apparecer a furto sempre envergonhado. A destruiçảo deste escondrijo mourisco poria as senhoras na precisáo de vestir-se melhor para chegarem ás janellas, a satisfazer a natural curiosidade de verem, e serem vistas, e assim familiarizando-se com o sexo masculino, nảo olhariáo como virtude o insocial recolhimento, que as faz evitar os homens, como a excommungados.

Teriảo occasiảo de conlsecerem os caracteres dos que visitảo seus pais, e parentes, e dariảo mutuamente a conhecer os scus. Então os casamentos, tanto mais felizes, quanto menos sujeitos a enganos occasionados por falsas informaçóes, seriảo acompanhados de natural affeição ganhada no trato civil dos dois sexos, que he a melhor escola da civilidade.

Ella o he tambem do amor puro, e delicado, que realça o espirito, e cria sentimentos nobres, e generosos. Com os actuaies costumes săo as escravas quem logra as primicias do amor dos nossos mancebos, que esgotando com cllas, e com as meretrizes sua debil saude, se tornăo incapazes de gostar as doçuras do amor conjugal. E 8. finalmente. O systema que adoptámos de aldear os Indios em provoaçổes separadas; que foi o mesmo que deixa-los entregues á 


\section{(4:}

sua natural inercia. Năo he lá entre as matas, que a civilisảção póde fazer progressos. Só a estreita comínunicaçăo comnosco, a vista dos espectaculos, er festins. poderá excitar nelles o appetite das commodidades da vida social; o desejo de parecerem bem, e distinguir-se, o gosto em fim dos prazeres superfluos, cujo estimulo só he que será capaz de obriga-los a tomar o habito do trabalho, vendo que năo tem outro meio de alcançar. aquelles prazeres. Mas he necessario persuadi-los que häo-de a seu arbitrio dispôr de todo o fructo do seu trabalho, dando-lhes disso huma perfeita segurança, que só poderảo ter vivendo entre nós, e desfructando cada hum seu predio em pleno dominio sem sociedade, que além de ser mải de discordias, paralysa a industria dos quinhoeiros, que năo trabalhăo bem, quando nảo trabalhão para si sós.

Huma boa policia economica multiplicaria indefinidamente vassallos tanto mais uteis, quanto săo doceis, e obedientes.

Póde enurrerar-se entre as causas, que obstảo á pcvoaçăo do paiz, o monopolio que logrăo os Medicos, Cirurgiổes, e Boticarios.

Porque elle concentrando em hum pequeno numero de pessoas o exercicio destas artes, difficulta a diffusăo das luzes habilitando os Officiaes de saude para fazerem o que se chama carrapata, e dispensando-os do trabalho de estudarem até por falta de tempo. Permitti o tratar dos enfermos a todos os que tiverem para isso inclinação, e vós vereis hum grande numero de homens de letras, e curiosos, applicarem-se á arte de curar; pôrem-se em estado de discernir os charlatáes, e obriga-los pela sua concurrencia a estudarem, e cuidarem seriamente dos seus doentes. O Boticario, diz Smith, he o Medico do pobre. Os nossos Parro- 


\section{$(42)$}

chos o seriảo tambem, se a Leillhes nảo inhibisse huma pratica bem digna da caridade christâ. Elles sabem ao menos ler, e escrever, o que nem sempre se encontra nos que obtiverăo cartas d'exame, e licençaș para curarem, aliàs cartas de seguro para matarem impunemente pela cega confiança, que o povo sincero pổe em semelhantes cartas, que, a nắo serem ellas, averiguaria a capacidade dos Cirurgióes a quem se entregasse. Sảo bem conhecidos alguns Lavradores do Reconcavo ; que por caridade curäo muita gente com feliz successo ; como o Senhor do Engenho do Pocico ponto , e ha mesmo dentro da Cidade até pessoas do sexo feminino, que exercem a Pharmacia com mais perfeiçăo que muitos Boticarios encartados, as meninas do Senhor Joăo Ladislau, cuja botica he a maisaccreditada.

O principal de todos os meios, com que se podè facilitar aos Lavradores o exercicio da sua industria, aquielle que serve para se haverem todos os outros', e sem o qual elles ficariáo inuteis, he o fornecimento de fundos para pôrem em valor as suas terras, que por falta delles ficăo incultas. A mais industriosa povoaçăo sería inutil, e até onerosa, sem os fundos indispensaveis para the fornecer salarios, instrumentos, sementes, e materias, em que pudesse empregar o seu trabalho. E posto que eu esteja bem longe de aconselhar nenhuma direç̧ăo de fundos para a Lavoura com preferencia a qualquer outra industria, estando certo de que havendo liberdade de Commercio, elles hăo de tomar a direcçăo mais conveniente, até se equilibrarem as vantagens em todos os empregos, todavia nắo posso deixar de notar alguns obstaculos, que embaraçando a livre circulaçảo, retardảo o restabelecimento daquelle natural equilibrio," retendo fóra da Lavoura capitaes, que iriảo para ella no estado de liberdade. 


\section{(i 43$)$}

Tal he a taxa do juro do dinheiro, que sendo muito inferior ao seu preço natural n'huma tão vasta Colonia, inculta, e recheada de escravos, impede que venhăo para ella capitaes estranhos dos paizes, onde o seu uso tem menos valor. Sería para desejar que as mesmas providentes Leis, e ordens, que abolírão as taxas dó preço dos generos no Brazil, comprehendessem tambem este resto do systema taxativo.

J. B. Say expoz os inconvenientes de semellhantes taxas com a sua costumada sabedoria no Trat. d'Economia politica L. 4. C. I4 e I.5'; e já antes delle os tinhão feito vêr o celebre Smith nas suas profundas indagaçỏes sobre as causas da riqueza das Naçốes L. 2. C. 4., e o seu annotador Garnier em a nota 22.

A taxa do juro năo só impede a introducçáo dos capitaes estrangeiros, mas faz que o Lavrador nem esses poucos, que existem, possa conseguir ; por que os capitalistas achắo. para elles emprego mais lucrativo que o juro da Lei. Donde vem que o Negociante, nas occasióes de urgencia, difficultosamente alcança dinheiro para remir huma letra, ou precisão extraordinaria, e o Lavrador pobre náo pode obter seus supprimentos; senăo em generos fornecidos por preços exorbitantes, que em poucos annos o arruinäo, sendo obrigado a deixar ficar os Engenhos de fogo morto, como vemos hum grande numero delles. Náo succederia assim, se mais illustrados nos principios da sciencia cconomica, facilitassemos aos capitalistas o exercicio do seu direito de propriedade. Porque entăo lançariắo na circulaçắo o dinheiro que tem enthesourado, ou empregado en paizes estrangeiros, principalmente nos bancos dos Estados Unidos, e Grä Bretanha.

Nos seculos da ignorancia, e superstiçáo, pensavase que pelo uso do dinheiro năo era licito levar o.respe- 


\section{(44)}

ctivo aluguer, ou renda delle, chamado juro. Designava-se este pela palavra infamante de usura. Náo porque naquelles tempos se ignorasse que o uso do dinheiro prestava ao mutuatario utilidades proporcionadas ás que prestava o uso de huma casa, ou de huma besta; mas porque no dinheiro se costumava gravar o signal da Cruz. Ao depois penetrando as luzes na Europa, sentiose todo o absurdo d'aquelle erro; e hoje nos paizes civilisados năo he preciso estipular juros. Qualquer que compra a credito o seu vestido na loja do Mercador, conta com a satisfaçảo do competente juro até o dia da soluçăo; e assirn giráo os capitaes livremente das mảos dos ricos para as dos pobres por hum modico interesse reduzido ao mais baixo preço, pela immensa cancúrrencia dos capitalistas, que drăo achando infamante este negocio, se apresentáo em multidăo a offerecer seus fundos aos necessitados, e aos industriosos, que entảo năo deixăo de emprender qualquer especulaçăo por falta de meios pecuniarios. $O$ Brazil porém conserva ainda as antigas idéas: dos seculos da ignoranicia, e a taxa do juro do dinheiro muito a baixo do seu preço natural, donde proven que huma beà parte dos que podem apanhar dinheiros alheios; taes como Thesoureiros, Commissarios, Procuradores, Feitores, Tutores, Administradores, Testamenteiros etc., os retem annos, e annos, e até sustentáo litigios os mais renhidos para conservarem nas unhas hum capital, de que tiráo ordinariamente 12 por cento de lucros, estando certos de que os juros sómente thes serăo contados a 5 , quando forem compellidos a restituir o que $\mathrm{cm}$ si retem contra vontade dos seus donos:

A instituiçăo de bancos de circulaçăo, e de soccorro, que introduzissem no giro commercial os fundos extraviados delle, ou hum armazem. da natureza. 


\section{( 45$)$}

do de Stockolmo, de que falla o Author do Projecto Economico P. I. C. 15, pareciảo ser o meio mais opportuno de remediar aquella falta de capitaes. Em lugar delle se adoptou o expediente de conceder aos Lavradores o privilegio de nảo poderem rematar-se as fabricas de séus Engenhos por execuçăo dos crédores. Mas este remedio veio ainda aggravar o mal; porque the augmentou as causas, que consistiáo na difficuldade de' obterem capitaes, e na facilidade de dissiparem em superfluidades os que possuiăo.

Vaidoso com esta prerogativa, que parecia realçar - lustre do seu titulo de Senhor de Engenho, elevando-o á qualidade de morgado, elle năo receou mais a pobreza e huma porçã่o dos fundos, que devia converter en capitaes, empregando-os: nos trabalhos productivos de sua Lavoura, foi reservada para o seu serviço pessoal.

Por outra parte a consideração do privilegio aterrou os capitalistas com a feis perspectiva da maior. difficuldade de reembolsarem os fundos, que emprestassem. Em consequencia muitos fugírăo de contratar com huma classe de homens, que a Lei privilegiou com a faculdade dé serem caloteiros impunemente.

Diminuio por tanto a concurrencia dos que emprestavāo á proporçăo do novo risco accrescido pelo privilegio, ficando sempre igual a dos que tomavăo emprestado, e por conseguinte devia crescer a exigencia dos crédores em prejuizo dos Lavradores honrados, e proveito unicamente do pequeno número ' dos que săo caloteiros, que com a isca de maior premio sempre apanhắo alguns vintens. $\mathrm{E}$ como entre nós pela lamentavel falta de hum Registo de hypothecas năo póde nunca o crédor conhecer a solidez das que the offerecem, ficando sempre exposto ás bulras dos velliacos, que obrigáo o mesmo prédio a dous ou tres, deve $\mathrm{cm}$ 


\section{( 46$)$}

consequencia perpetuar-se aquelle descredito geral dos devedores pobres, ainda que tenhăo hypothecas livres, huma vez que a Legislaçăo actual năo deixa provar que o săo.

A simples publicaçáo de huma Lei, que declarasse nullas todas as hypothecas em quanto nảo fossem averbadas no Registo respectivo (o da situaçăo do prédio) accrescentaria immediatamente ao valor da riqueza territorial muitos milhóes; porque desde essa época os proprietarios poderiăo mostrar com huma certidăo extrahida do competente livro a liberdade de qualquer dos seus prédios, ou os encargos todos a que elle estivesse obrigado; e cessando entáo para o comprador o perigo de lho revindicarem, ou de ser obrigado a pagar alguma divida a que o prédio estivesse hypothecado, nảo duvidaria entảo offerecer por elle muito maior preço á proporçăo da maior segurança, com que comprava.

Avaliando muito por baixo a propriedade territorial em 900, milhóes, e calculando este accrescimo de valor a IO por cento, montaria a 90 milhỏes o beneficio do Registo de hypothecas, além das vantagens de livrar a Nação de mil pleitos, que trazem sua origem das bulras, e velhacadas, a que dá lingar a falta d'aquella providente Leị. E tudo isto sem trabalho, riscos, nem despezas; antes proveito para os Officiaes, que houvessem de passar as certidóes.

As vergonhosas delongas dos procéssos pendentes do arbitrio dos Juizes, Advogados, Escrivăes, e outros Officiaes de Justiça interessados na demora pela maneira, com que se tem provido ás suas subsistencias com emolumentos contingentes; a multiplicidade das fórmulas, que póe os Cidadáos á mercế dos Procuradores; a maneira de contar as custas conforme as ta- 


\section{( 47 )}

xas, que năo se observăo, senảo contra o vencedor, o qual por isso nunca póde ser indeninizado pelo vencido condemnado nellas, augmentando as difficuldades do reembolso aos crédores, tambem afastăo grandè número de Capitalistas, obrigando-os a nảo largarení de si a administraçăo de seus dinheiros, posto que menos productivos na sua măo, do que o seriăo emprega 2 dos por habeis Lavradores. Digo habeis, porque algunis ha tăo pobres de espirito, e de bens, que fariăo maior serviço ao Estado se abandonassem suas terras; e fắbricas a outros, que tem mais indústria, e capitaes, para aproveita-las.

Isto faz lembrar ainda huma 'reflexăo contra o privilegio d'amortizaçăo dos Engenhos; e he que, "se fora livre a sua circulação, por meio das arremataçổes, passariảo regularmente para a măo de póssuidores maiș habeis, e ricos, que pudessem tirar delles todo o partido possivel, do que năo șăo capazes os cxicutados, que por isso mesmo," que chegárăo ao ultimo termo de viva execuçáo, derăo a conhecer a sua natural indolencia, ou incapacidade, e a falta de credito, com que pudesșem obter os fundos necessarios para costea-los utilmente. Năo bastavão tantos predios, que os vinculos, e as corporaçốes religiosas tem subtrahido á circulaçẳo! Valha-nos Deos!... Aquelles, que para conservarem suas propriedades carecem de privilegios amortizadores, náo săo proprios para aproveita-las da maneira mais vantajosa ao Estado, nem para illustrarem, ou edificarem seus Concidadáos com exemplos de bons costumes, e serviços correspondentes a tal sacrificio:

Năo săo só as mencionadas Leis amortizadoras, que paralysăo a industria agricula, impedindo que os capitaes passem para as mäos, onde săo mais productivos. O mesmo effeito produzen, mais ou menos, to- 


\section{(48)}

das aquellas que offendem os direitos da propriedade; embaraçando o cumprimento dos contratos. $\mathrm{E}$ desgraçadamente dellas temos táo grande copia, que bem mostrắo ser alguma classe privilegiada, quem tem principalmente influido na moderna Legislação, para a fazer desviar dos principios da justiça natural, e bem commum. Bastará a pontar algumas; por exemplo: $10^{2}$ as que izentáo de penhoras a certos bens, como as seges e suas bestas; privilegio, que só serve de alimentar o luxo escandaloso dos, devedores, para com elle insultarem a seus crédores, os quaes ás vezes sáo miseraveis orfăos, ou viuvas, que desses fundos se alimentăo, ou pessoas.industriosas, que os empregariáo em despezas productivas, para augmentarem a riqueza nacional: 2." as que embaraçáo effectuar-se as ditas penhoras em certos lugares, como nas Alfandegas: $30^{\circ}$ as que sim deixăo penhorar, mas nả̉o arrematar, e só pagar por consignaçóes, no que vem a pagar menos do que deveın, pela regra de Direito $=$ quem mais $t a r$ de paga menos paga: $40^{*}$ as que em vez de fazerem pagar a divida ao crédor, pelo contrario o fazem experimentar grave lesáo, como a que lhes manda adjudicar contra sua vontade os bens penhorados. Para o que năo tem o devedor mais do que peitar os avaliadores; que peitados estes (o que desgraçadamente năo custa muito) avaliăo entáo o predio $\mathrm{em}$ muito mais do seu verdadeiro valor, e por effeito daquella Lei se adjudica ao crédor exequente com o abatimento da $50^{2}$ parte. Por esta arte o predio, que vale 10 contos de réis, avalia-se em I5, e se constrange o crédor a toma-lo por I 2 , vindo a perder pela violencia da adjudicaçăo 2 contos de réis, em vez de cobrar o que se the devia. O verdadeiro valor de huma cousa he o que se póde obter por ella n'hum mercado publico, e livre 


\section{(49)}

concurrencia: $50^{2}$ as Leis d'aposentadorias, que se tem estendido até aos carniceiros, authorizando-os a reter. a casa alheia contra vontade de seu dono a despeito da Ord. L. 4. N. ${ }^{2}$ 23. , que tinha consagrado o dircito desta respeitavel propriedade. $\mathrm{Na}$ sua origem o regimento da aposentadoria năo escandalizava, porque cra contido nos limites da necessidade, e adoçado com a competente indemnizaçăo da violencia ; pois se tomavăo casas sómente para os criados, e Officiaes de Justiça, e Fazenda, que acompanhavắo a ElRei nas Correiçó̉es, que entäo fazia pelo Reino, a corrigir os abusos. Durava a occupaçăo pouco tempo, e se pagava pontualmente adiantada a competente renda); termos, en que o passageiro incomodo do despejo era compensado pelas vantagens da Real Correiçẳo, e adoçado pela consideração da sua necessidade; pois sem aposentadoria sería forçoso que aquelles Officiaes d'EIRei pagassem casas em todas as terras do Reino; porque nem estalagens havia ainda naquelles tempos, nem podião adivinhar a que terras haviăo de ir: $60^{2}$ a Lei das inducias, que obriga os crédores de menores quantias a acceder aos maiores, para concederem esperas ao devedor commum sem vencimento de juros, e sem as devidas seguranças. Em semelhantes arranjamentos săo regularmente lesados os crédores sinceros. $\mathrm{Na}$ da ha mais facil do que figurar hum ou dois fantasticos, com a somma que baste a vencer os verdadeiros, que por este meio ficăo fraudados. $\mathrm{E}$ assim succede que esta Legislaçáo corta a raiz do credito commercial, abslando a confiança, e fomentando a immoralidade, e collusóes. Authorizar hum devedor para que pague mais tarde do que ajustou he authoriza-lo para que pague menos do que deve L. I 2 . in fin. ff. de verb. signifi. L. 22. \&.I. ff. mandat. $\$ 3$. Inst. de 


\section{$(50)$}

Action. Se ao menos se tomassem às cautelas proprias a prevenir as collusóes, como se pratíca em França, e outras Naçóes illuminadas; toleravel sería o damno.

7." He da mesma forja a nova Lei dos falidos authorizando-os a levar 8 por cento á custa dos seus crédores, ainda quando entrárắo na profissăo sem fundo algum, e concedendo-lhes ao mesmo tempo duas naturezas, de vivo e morto; vivo para poder immediatamente enriquecer-se, e morto para năo ser mais obrigado a pagar o que deve. As fraudes, a que esta Lei tem dado lugar, săo tăo sabidas, que ha quem julgue da opulencia de hum Commerciante pelo numero das vezes que tem quebrado, ou feito ponto.

Muitos crem seriamente que he hum bem para - Estado dar a mäo a estes falidos, ainda com o sacrificio da justiça, por lhes parecer que d'ahi vem beneficio ao Commercio nacional. Năo pensariảo assim; se, possuindo solidos principios de economia politica, advertissem que a massa do Commercio, e vantagens que delle provêm, năo dependem do numero, nem dos. nomes dos Commerciantes; mas da sua capacidade, dos capitaes, e do credito, que os habilita para encherem o objecto da sua profissão, que he facilitar as trocas, e consumos das producçỏes. Ainda que faltem alguns Commerciantes na lista da matricula, năo deixa por isso de ser exportada toda a colheita annualmente produzida, e importada igual quantia dos generos, que nos săo precisos. Só variăo os nomes das pessoas, que antes compravăo, ou vendiăo; e quando em vez de hum que falio se effectua o transporte por conta de outro, a Lavoura nảo perde nada, e o Estado ganha em passar o capital da mäo de hum Commerciante pouco habil, economico, e previdente, (como os falidos costumăo ser) para a de ontro que se presume mais 


\section{(51)}

capaz, e acreditado, por isso mesmo que soube haverse, e sahir ben, negociando no mesmo lugar, e tempo, em que o outro sahio mal.

Em tal caso deve o falido descer hum gráo na escala da sua dignidade, passando a Guarda livros de algum seu Collega, ou a administrador d'alguma entpreza industrial, ou tomar outro destino accommodado ás suas circumstancias, e capacidade, no qual fará ao Estado maior serviço do que lhe poderia prestar, se a torto, e a direito fosse mantido na drdem de Commerciante, em que năo pôde sustentar-se. nem por si só, nem pelo auxilio dos amigos. Torno a dizer, aquelle, que, para conservar os seus bens, carece de maior favor que os outros, nảo he tăo capaz como elles para regê-los da maneira mais vantajosa ao Estado, cujo interesse em tal caso he, que os fundos passem para mảos habeis, activas, e economicas, que possảo tirar delles todo o proveito possivel. He hum meio de fomentar a industria. $O$ contrario he proteger a negligencia, o luxo corruptor, e a immoralidade.

Conservar estas Leis em vista de prejudicar os crédores estrangeiros, que tamben soffrem damno com as quebras, he erro tảo contrario á justiça, como á sá politica, nascido dos falsos principios do systema exclusivo, que cuida poder firmar solidamente a riqueza nacional sobre a pobreza, e lesão d'aquelles, com quem negocêa. Cara nos sahe essa mesquinha fraude ; porque - descrédito, que d'ahi provem ao nosso corpo do Commercio, afasta os Capitalistas estrangeiros de nos confiarem os seus capitaes, fazendo-o sómente por hum preço tanto maior quanto maior he o risco, que semethantes Leis o fazen correr. 8. ${ }^{2}$ He do mesmo cunho a extenção, que muitas vezes se dá ao privilegio dotal; porque ainda que a Lei o nẳo faculte, senáo em 


\section{$(52)$}

prédios estimados, precavendo fraudes, na pratica se amplia a quantias imaginarias, e năo falta quem os queira sustentar ainda contra as expressas convençốes das proprias 'mulheres, quando prestăo sua traidora assignatura em apoio das bulras armadas pelos marides aos Capitalistas sincéros, que lhes ccnfiáo seu dinheiro. Que differença entre o nosso foro, e o Inglez! Neste, longe de acharem os devedores apoio para fraudarem a seus crédores, e lhes demorarem o pagamento do qque devem, muito pelo contrario sáo logo recolhidos á cadeia se năo segurăo o Juizo comidónea fiança, oir mostrăo sua conta liquidada. Legislaçăo, que os velhacos acháo contraria á humanidade; porque ella os esfrega; mas que os sábios em economia politica reconhecem como a base do crédito, que geralmente logrăa os Inglezes, e que dá extensăo ao seu Commercio; porque ella os póe na precisăo de procederem honradamente ao menos na apparencia, observando pontualmente'sua palavra, scm o que năo acharăo fiadores, que os salven da prizáo quando forem demandados pelos seus crédores.

Sendo o rigor da Justiça necessario a qualquer pot vo,- o he com especialidade áquelles, que como nós, e os Inglezes, precisäo estender a sua navegaçăo a longas viagens; porque nestas he forçoso dar aos Capitáes dos navios, e Sobrecargas ampla authoridade de contrahirem emprestimos por conta dos donos, para acudirem aos reparos, provimentos, e mais necessidades supervenientes n'aquellas remotas regióes, e cumpre por isso que elles tenhăo para a administraçăo delles capacidade, e fidelidade tanto maior, quanto maior he a distancia em que se aclắo das vistas dos donos. Mas para se acharem muitos homens capazes de tăo melindrosa commissão, he forçoso que haja rigor no castige 


\section{(53)}

das malversaçôes. Quantas especulaçôes deixăo de emprender - cs Capitalistas, por năo descobrirem hum caixa capaz de se lhe confiarem! Quantos deixáo de comprar huma roça, por năo acharem feitor capaz de tha administrar! A experiencia dọs muitos, que á sombra das ditas Leis, e outras do mesmo cunho, tem ficado com os fundos alheios, sem darem conta delles, obriga os donos a subtrahi-los á circulação, náo os deixando ir fecundar a terra, e alimentar o traballho productivo, sem juros enormes proporcionados á grandeza do risco.

Outra causa năo menos poderosa que tambem influe para a mesma estagnação dos capitaes; e consequente augmento do seu juro, he a longa duraçăo dos pleitos, a qual grandemente auxilia os caloteiros para que jámais os Capitalistas possăo realizar a cobrança do seu dinheiro sem incommodos intoleraveis; porque está de tal maneira arranjada a Legișlaçăa do processo, quue obriga os Juizes a olharem para as măos das Partes, de quem recebem emolumentos accidentaes proporcionados á duração dos pleitos, em vez de terem ordenados fixos, ou quotas proporcionadas ao seu valor, donde houvessem sua subsistencia com maior dignidade.

O systema, emolumentario faz que todos os empregados na administraçăo da Justiça tenhẵo interesse em multiplicar, complicar, e prolongar os processos; porque quanto mais estes se multiplicảo, complicăo, e prolongăo, mais crescem assignaturas para os Julgadores, allegaçóes para os Advogados, escriptas para os Escrivăes, e salarios para os solicitadores; sendo assim interessados em desunir, e enredar os Cidadäos. $=$ Deos desavenba quem nos mantenba. = Eis-aqui a oraçăo matutina que thes inspira o tal systema emolumentario. A' vista delle não he muito que vejamos a Naçáo dị i- 


\section{(54)}

dida em bandos por todas as terras fazendo-se mutuamente os povos huma guerra surda d'intrigas sem idéa de patria, e'sem a respeitavel consideraçăo, e força publica, que só provem da unijăo das vontades. Nẳo he muito, que se veja em esqueciinento a benefica Ord. do L. 3. Tit. 20. \$. 4, que lembra aos Juizes as concordias das Partes no começo das demandas; que os Juizes arbitros tenhăo cahido em desuso ; que se recebäo geralmente artigos impertinentes, embargos de materia velha, aggravos de petiçăo fora dos casos prescriptos na Lei, reformas de termos contra a sua determinaçăo. Năo he muito que se nả̉o costumem impôr as penas decretadas contra os Advogados, e Escriväes que demorăo em seú poder os feitos aléni dos termos legaes. Năo he muito em huma palavra, que se achem sem vigor tantas Leis promulgadas para abbreviar os processos. Mude-se o systema emolumentario, substitua-se por outro que seja talhado por quem tenha dedo de Legislador, vêr-se-ha logo essa massa d'engenhos, ora applicada em alambicar-subtilezas forenses, voltar suas vistas para objectos d'industria proveitosa, em augmento dós productos deste precioso Torráo.

Em vez de taxar o preço dos salarios aos trabalhadores, dos fructos aos Lavradores, dos alugueres aos proprietarios, e dos juros aos Capitalistas; eu taxaria o tempo dos pleitos, como já em parte se aclia feito a respeito d'alguns; como os das suspeiçóes.

Hum anno para ás causas ordinarias, hum mez para as summarias, e hûm dia para as verbaes seriâo talvez prazos sufficientes para a sua terminaçăo, responsabilizando-se todos os Officiaes, que interviessem no processo pela prompta expediçăo delle, principalmente - Juiz, que sería sequestrado logo que espirasse o prazo legal, sem estar julgada a causa. E nada' deveriăo 


\section{(55)}

receber da quota proporcionada ao valor da causa; que the havia de tocar pelo seu trabalho, senăo depois de finda a instancia. O mesmo ordenado em vez de se pagar adiantado aos Desembargadores, como a Lei manda, se thes ñăo devềra dạ sem certidáo de terem despachado todos os feitos respectivos ao quartel.

Se esta providencia pouco infuisse para a prompta execuçáo delles, serviria ao menos para dar a conhecer os preguiçosos.

Mas năo basta que os processos sejẳo breves, cumpre tambem que as decisóes sejăo justas; porque sem isto nảo se obtem huma perfeita segurança dos. direitos de propriedade, e do cumprimento dos contratos, que he o primeiro objecto da sociedade civil, e o mais interessante dos auxilios, com que hum Governo pode facilitar aos Lavradores o exercicio da sua industria, e a livre circulaçáo dos capitaes. He objecto universal de todos os votos, e o mais digno de occupar a attençáo dos que governăo. Eu nảo duvido que VV. SS. as a proveitem a presente occasiăo de fazerem chegar esta importante verdade aos ouvidos de S, A. R; pois que se digna ouvir essa Camara sobre as necessidades do povo, que term a seu cargo. E nenhuma he maior certamente que a da Justiça Năo ha ninguem que o desconheça; porque até os anexins populares o publicáo a cada passo.

Huns falláo das mangas da Justiça, outrọ da de compadres; se se lhes pergunta se huma cousa he sua, respondem $=E m$ quanto os Senbores Desemibargadores quizerem; $=$ Lá väo Leis onde vós quereisés dizem os outros. Comparăo-se os litigantes a hum lançol nas mảos das lavadeiras, que o năo largăo em quanto the sentem churume. Ficâo a final bum ni, ouf tro em camisa óca orc. 


\section{(56)}

E perguntando-se o remedio a este damno tăo geralmente reconhecido, e lamentado, ninguem o dá. =Em quanto os bomens forem os Fuizes, dizem todos, bĩo de as paixöes dominar: sempre assim foi. = Todavia eu ouso crer que o mal năo he sem remedio, e até me parece ben obvio.

O ponto está que se ache hum homem d'aquelles, que valem huma Nação, segundo a expressão do nosso D.r S. a Lx.a ; que saiba remontar ás causas, e senhorear-se dellas para as destruir.

Quaes săo as causas das injustiças? Todas quanto a mim se encerrảo em duas, que vem a ser: $1 . "$ incapacidade dos Julgadores, pela qual nảo podem muitas vezes distinguir o justo do injusto, sendo obscurecida a materia pela artificiosa eloquencia dos Advogados, formidaveis neste particular: $20^{\text {a }}$ as paixóes do interesse, amor, odio, amizade, temor, e respeito; e tambem a preguiça de fazerem o preciso exame.

Para destruir a primeira causa, reforme-se a Universidade, e estabeleção-se outras mais, nas quaes em lugar de embotar os engenhos da mocidade no árido estudo dos Codigos, Romano, e Canonico, tảo incomprehensiveis; contradictorios, e alheios da Filosofia dos tempos presentes; como se podia esperar de Leis concebidas por huma innumeravel multidão de cabeças diversas, que vivêräo pelo espaço de mais de vinte escuros seculos, adopte-se hum systema de instrucçảo publica, nivelada pelas luzes do seculo. Classifiquemse os gráos de illustração segundo a idéa do celebre Condorcet, este grande genio, que soube abrilhantar; e fazer entender a obra de Adam Smith sobre as causas da riqueza das Naçóes. E chamem-se para os Tribunaes só os que a opiniâo publica elevar á classe superior d'illustração, tendo provado sua probidade; e 


\section{( 57 )}

capacidade no exercicio d'outros empregos. Em quanto á segunda causa das injustiças, as paixúes, podem tambem paralysar-se os effeitos da sua acçăo com opportunas providencias; do que nos fornece bom exemplo a Gră Bretanha nas causas decididas pelos Jurados com experimentada utilidade.

Eu năo sómente adoptaria aquelle systema nos termos, em que os Inglezes o praticăo, isto he, nas questóes de factos simplificados, que todos os Cidadáos podem facilmente entender, e decidir sem estudos de Jurisprudencia; mas o applicaria tambem ás deliberaçóes dos Desembargadores, para os preservar da influencia das paixóes em seus julgados. Por exemplo; primeiro que tudo constituidos os Desembargadores n'hum gráo d'independencia, e consideraçăo, capaz de ser geralmente desejado pelos mais Cidadăos, eu restauraria o antigo estylo dos roes de pejados, que era hum dos principaes escudos da nossa antiga liberdade, pelo qual podiáo as partes recusar os Desęmbargadores, que não logravá́o a sua confiança; estylo, que; tendo servido a sustentar a coragem de nossos maiores nos tempos da antiga gloria Portugueza, foi desgraçadamente abafado á surdina por tres palavrinhas mettidas lá no fim de huma Ordenaçắo fugitiva, a do L. I. T. I. $\oint .15$, como se fôra huma bagatella; por cuja abrogaçắo se apertou mais o monopolio de julgar que tem os Desembargadores, e que se tornou tanto mais duro, quanto pela outra Ord. L. 3. Tt. 2 I e 22 se difficultou ás partes a interposiçẳo das suspeiçóes, e sua prova. Restaurado o antigo foro dos roes de pejados; sagrado paladio das nossas liberdades, e propriedades, ficava ás Partes franco o meio nảo só de se livrarem dos Juizes seus inimigos, ou amigos da Parte contraria, mas tambem de excluirem os outros, que năo fos- 


\section{(58)}

sem capazes. E estas exclusỏes envergonhariăo aos Desembargadores, que por fracos, ou golosos vissem seus nomes nuitas vezes no rol dos pejados, e seriảo parte para se emendarem, e para os outros năo seguiren o mesmo trilho.

Depois eu daria as providencias necessarias, para que processo algum jámais se estendesse a ponto de náo poder ser despachado em algumas horas, v. g. hum imposto progressivo nas folhas que excedessem a 200. Isto feito, a casa da Relaçăo se construiria de maneira, que $\mathrm{cm}$ torno della haveriăo tantos gabinetes, quantos fossem os Desembargadores, tendo cada hum o seu, com os Livros, e tudo o mais necessario para o despacho dos feitos. E recolhendo-se cada $\mathrm{Mi}$ nistro ao seu á hora do despacho, a sorte decidiria o feito, que lhe havia de tocar, e sem que este fosse despachado nảo sahiria do Gabinete, nem poderia ter communicaçáa com pessoa alguma, e o despacho sería irrevogavel. No dia seguinte a mesma sorte decidiria, qual deveria ser o segundo Juiz, e assim o $30^{\circ}$ ou mais se fossem percisos para o vencimento do feito. He escusado declarar que se teriăo tambem removido os obstaculos, que impedem actualmente a prompta, e exacta decisăo, como v. g. a insensata pratica de tencionar n'huma lingoa estranha, corruptela, que influe mais do que se pensa para a ruin administraçăo da Justıça; pois difficulta exprimir com énergia, e clareza os fundamentos de cada hum, e faz que se năo escrevăo todos os que se escreveriaio, se fosse na propria lingoagem.

Com tal systemá nảo podiāo os Ministros ser seduzidos pelas Partes; pois estas ignoravão a qual delles pertenceria o seu feito, e sendo todos perfeitamente independentes, nem o temor, nem o respeito faria 


\section{( 59 )}

nos seus animos impressăo capaz de obriga-los a torcer a vara, para serem objecto do desprezo de seus Concidadãos. Porque para o sabio independente a paixăo mais forte he a do amor da gloria; nem sem esta póde elle sujeitar-se ao improbo trabalho, que o conduz á sabedoria, como observou Helvecio. Se he sabio, tem vergonha; e o que a tem nảo he ladrăo.

Ora mais que ladräo he aquelle, que para transtornar as propriedades se serve do poder, que se the conferio para as segurar.

\section{TERCEIRA CLASSE.}

Das causas nocivas a Lavoura provenientes da falta d'instrucçẵo.

As liberdades, e as facilidades concedidas aos Lavradores para o exercicio de sua industria serío mediocres vantagens, se elles, nạa form instruidos nos methodos mais commodos de se aproveitarem dellas. O Tribuno Say já citado observou logo no principio do seu incomparavel Tratado d'Economia politica a grande parte, que as luzes do sabio tinhăo na producçảo das riquezas; observaçăa, que se verifica em, toda a casta de Sciencias e Artes pelo nexo, que liga todos os conhecimentos humanos. Nạo se espere ver. huma peça de panno bem fabricada onde se ignorar a Astronomia, dizia o grande amigo de Smith, o primeiro. Mestre dos Historiadores modernos. Sendo certo que todas as Sciencias concorrem para a multiplicaçăo das riquezas, que diremos d'aquella, que tem precisamente por objecto essa mesma multiplicaçáo, a economia politica?

Só as luzes, que esta diffunde, podem preservar fos que governäo das suggestộ,es regulamentarias, $\mathrm{f}_{\mathrm{f}}$ - 


\section{(60)}

Jhas do espirito do monopolio táo vulgar, como infausto á Lavoura, e descobrir as causas da pobreza para as remediar; e só ellas podem fazer ao mesmo tempo que as boas providencias surtáo pleno effeito pela convicçẳo da sua utilidade. He o habito deste estudo, que inspira no coraçảo do homem o amor da Patria, e da humanidade, por aquelle principio que nos leva insensivelmente a amar os objectos das nossas contemplaçỏes; pois sendo o desta Sciencia conduzir os homens á felicidade pela producçăo, multiplicaçăo, e bom uso das riquezas, o Economista näo contempla senăo o bem da sua Patria, e da humanidade. Todo occupado dos meios de alcança-lo, (que se refundem na prática da justiça, e da virtude) elle nutre o seu coraçẩo destes puros sentimentos, arraigados pelo intimo conhecimento da sua importancia.

Illuminando seus Concidadăos move-os a fazerem dos bens, que possuem, o emprego mais conveniente, influindo-lhes o gosto das despezas productivas, e uteis ao Estado. Gastão os moradores desta Cidade espontaneamente mais de meio milhăo por anno em funeraes, e festas d'Igreja, e nem hum vintem em caminhos, cáes, fontes, pontes, e obras uteis. Se em vez de lerem vidas de Santos cheias de piedosas fraudes, lessem livros desta Sciencia sublime, suas despezas se encaminhariāo como na Grä Bretanha, para dockes, e outras obras patrioticas.

Ainda se nảo vio hum Economista que fosse máo Cidadảo, diz o grande Say no Prefacio do seu insigne 'Tratado. E esta consideração, ainda năo desmentida, justifica ao célebre Dupont de Nemours, que primeiro entre todos os Economistas demonstrou que este estudo pertencia a todas as classes de Cidadáos, sem exceptuar o bello sexo: (no Prefaçio da Phisiocracia ou, 


\section{(6I)}

Constituição natural do Governo mais vantajoso ao genero humano.)

He a elle principalmente que a Grä Bretanha deve a moralidade de seus Concidadăos, e a integridade, e promptidăo que se notăo na administraçăo de sua justiça, a qual fazendo inviolaveis os contratos, e direitos da propriedade, consolidou o crédito geral dos seus habitantes, e Governo, elevando-a ao ponto de fazer pasmar o Universo com o brilho de sua opulencia, reconhecida pelos seus mesmos inimigos: (J. B. Say no Tratado já citado L. I. Cap. 25. Fazei que o Tratado deste grande homem seja lido com attençăo sequer ao menos pela centessima parte dos nossos Compatriotas, e eu vos asseguro que a amada Patria subirá logo a hum gráo superior de prosperidade; porque a natureza nos he mais propícia que aos Inglezes, e năo estamos acabrunhados com huma divida enorme.

Sabe-se o abandono em que esta Sciencia está entre nós, năo tendo havido nunca nem huma só Cadeira, que a ensinasse. (a)

Passando ás Sciencias Physicas. Para se formar huma idéa da importancia, e ao mesmo tempo da falta que temos dos seus conhecimentos, basta comparar os antigos productos do Engenho da Ponta com os

(a) A instancias do Author desta Carta mandou posteriormente ElRei crear huma Cadeira d'Economia Politica no Rio de Janeiro pelo D. dado na bahia em 23 de Fevereiro de 1908 , nomeando para ella o Doutor José da Silva Lisboa, que levou comsigo para o Rio a esse fim. Mlas chegando áquella Corte tal parede the fizerăo os inimigos da luz, que inda náo deo a primeira lição. Tanto he certo que sem Constituição se tornão vắs as mais benéficas disposiçóes dos Monarcas? O actual Congresso derribará aquelle muro de bronze, que os Godoianos tem opposto ¿ diffusăo das luzes, espequado sobre a Ignorancia, Inconfidencia, e Inquisiçăo.

Noto do Editor. 


\section{$(62)$}

que delle extrahe actualmente o seu novo proprietario, o meu honrado amigo Manoel Ferreira da Camara.

Pela primeira reforma de fornalhas (que ainda năo estăo perfeitas) aproveitando melhor o assucar, economizou dous terços da lenha, cuja despeza montava a mais de tres mil crizados cada anno.

1: Pela dos tubos da roda d'agoa conseguio que esta the durasse todo o tempo da safra, poupando-lhe o serviço de 70 cavallos, que antes erăo percisos para a moenda: pela da levada convertida em canal de condúcçăo, evitou grande numero de bois, e escravos, que occupava nos transportes das lenlas. Os mangues, que se julgavăo incapazes de produzir assucar, o dáo excellente. Já se năo teme falta de decoadas, nem săo custosas como dantes. Nảo se azeda o caldo, e a quaqualidade do assucar está na mäo do Lavrador.

Aquelle, de que en fallo, que póde servir de modélo aos outros, tem em menos de tres annos duplicado a renda do seu Engenho, cujo augmento accumulado clevará progressivamente os ulteriores productos na mesina proporçăo. De iguaes, e maiores progressos he susceptivel toda a Capitanía nos variados ramos de suas lavras. Pois se aquelle, que he de todos o mais fiorente, recebso lum tăo prompto, e extraordinario melhoramento, logo que o Filosofo empregou nelle as suas vistas vivificantes, quanto maior năo o receberiăo aquelles, cuja cultura está ainda no berço: como a canella, de que os Lavradores ignoráo até os ramos de que a devem extrahir, e o tempo da colheita; a pimenta, cacáo, baunilha, e mil outras drogas de grande uso nas cozinhas, e boticas?

A guaxims, macambira gravatá, caroá carrapicho, mbaúba, caraguatá, malvaisco, tocum, e outros linhos, apenas subministräo algumas cordas para o uso 


\section{(63)}

rustico, podendo fornecer materia' a importantes maçames, velames, e tecidos.

A simauma, e landgens das emas, e outras aves conı o mesmo algodáo, podião empregar-se nas fabricas de chapeos.

As ricas minas de prata, cobalto, ferro, cobre, azougue, e salitre săo como năo existentes. As mesmas de ouro cahírăo em decadencia, por se ignorar o melhor methodo de separa-lo, e as machinas percisas para a esgotaçẳo das agoas.

A immensidade de gado vacum podia dar manteiga, e queijo a todo o mundo, se soubessem fazelos, e melhorassem a raça com vacas turinas. A preciosa cochonilha, que se vende a pezo de ouro, cobre os sertóes de Jacuipe, Camisão, e 'Tapicurú sem que ninguem della se aproveite, pela năo saberem tirar, e preparar.

Bem quizera eu calcular a sonmsa de riquezas, que os Lavradores poderiảo tirar destes e mil outros productos, que a natureza lhes prodigalizou, se as luzes da Historia natural, Quimica, e Physica patenteassem os meios de aproveita-los. Mas quem poderia avaliar as vantagens, que a Lavoura póde receber das Sciencias? Sería perciso ser sabio para as comprehender, näo cabe na minha alçada.

E que se tem feito neste paiz a bem de táo importantes estudos? Nảo ha huma só casa de instrucçảo, e educaçăo, nem professores, que ensinem os primeiros rudimentos, nem hum nuseu, e biblipteca publica, (a) onde se possa achar o que se tem escripto, e descuberto.

(a) Já se estabeleceo huma muito boa, que até sutministra ljvros para os particulares os poderem lêr em stas casas. N. do $\mathbb{x}$. 


\section{(64)}

Nem ha hum horto botanico, para onde se transplantem os muitos vegetaes uteis, que nos faltáo; pois nem a arvore do páo temos ainda, havendo-a no $\mathrm{Pa}$ rá ; nem a da cera descuberta em Minas por Simáo Pires Sardinha; podendo ter tambem chá, que os Inglezes transplantáräo para as Carolinas, a nós muscada, cravo, e as mais especiarias, que os Francezes já cultiváo na Guienna, e Ilhas de França, e Bourbon, e as canas de Batavia, e as do Oitaiti já cultivadas nas Antilhas.

Năo temos finalmente nem ao menos huma Sociedade economica litteraria, que tomasse a seu cargo reanimar o patriotismo, fomentar a industria do povo, ensinar-lhe os melhores methodos de cultura, e artes.

Desconhece-se ainda o uso dos melhores instrumentos aratorios, das carretas Americanas, e barcos de vapor.

A Lei que inhibio levar escravos ao Reino, difficultou ás Colonias a acquisiçăa das luzes industriaes mechanicas; porque, se elles fossem francamente á Europa, aprenderiảo lá diversos methodos de trabalhar, e na volta introduziriảo muitos conhecimentos uteis que mos faltảo. Ha mesmo animaes interessantes, assim para o serviço como para o sustento do homem, que a Sociedade economica poderia fazer vir, taes como as zebras d'Angola, ovelhas de Guiné, cabras de Angora, e vaccas turinas.

Sente-se hoje o proveito que tiramos dos bois, e cavallos, trazidos da Europa. Os camelos năo o seriăo menos para as longas viagens dos nossos aridos sertóes, pelo muito caminho que avançảo soffrendo a sede. Ás cegonhas, e outros semelhantes que se alimentaáo de cobras; promettiảo beneficio á povoação. $\mathrm{E}$ os bichos da seda tăo proprios deste paiz quente, e 


\section{(65)}

cheio de amorciras, e fruteiras de conde forneccriảo abundante materia ás fabricas de sedas, principalmente os do Pará, que se nutrem tambem de folhas dé larangeira, e fazem 'o casulo' tres vezes maior que os ordinarios. Bem quizera eu discorrer sobre a immensidade de productos naturâes, "cón" que" se pódia enriquecer esta Colonia ; mas agora advirto que tenho einchido muitas folhas sem ter ainda respondido ao r.: Quesito, quando pensava que apenas havia indicado as cau'sas principaes nocivas á Lavoura! Sern duvida tenhơ abusado da paciencia dessé respeitavel Sénado. O excesso do meu zelo me fez diffíso, do que peço perdăo; è pois quie năo ha témpo de restúnir, vou ao menos emendar a măo no artigo da brevidade, que he o que está em meu poder. Eu passo á ultima parte dơ Quesito, en que se pergunta qual seja o meio de evitar os obstaculos que ficăo apontados.

E respondo que sendo elles conhecidos, e suas causas, obvios săo os-meios de evita-los; e como os limites, que me săo prescritos; năo permittem expeñde-los, só obrigádo a remetter-me ao zeloso economista, Abbade Boudeall, que os resumio na obra intitulada $=$ Aviso ao povo sobre a sua primeira necessidade, ou Tratados sobre a liberdade do Commercio dos: gráos, farinhas, e pão, Trat. I. Cap. 3 .

E a fallar a verdade eu năo conheço outros. Para as que procedem dos regulamentos o remedio lie revoga-los, e o officio desse Senado ficará alliviado da mais enfadonha, elimpertinente tarefa, reduzido àos dictames, que exprimio o nosso sabio' Doutor José da Silva Lisboa nó Cap. $50^{\circ}$ dos seus Principiós de economía politica, pelas palavras = deixai fazer, deixat passar, deixai vender $=\ldots$ Neste artigo governa mellior aquelle, que menos governa. A Administraçâo publica 


\section{(66)}

năo ten mais a fazer do que punir exemplar, e irremissivelmente os attentados do interesse particular contra a liberdade, e propriedade, precavendo a negligencia dos Magistrados no desempenho deste dever sagrado.

Para as que nascem da falta das facilidades o remedio he construir as obras, e fundar as instituiçóes acima lembradas: e os meios praticos achará esse Senado no Projecto economico de Bernardo War, obra que, vista por este lado, năo he destituida d' interesse, posto que manchada com os erros do antigo systema exclusivo. $E$, os achará tambem no exemplo das Naçỏes illuminadas, como a Gră Bretanha, e. Estados Unidos, onde commummente se fazem as pontes, estradas, dockes, etc. por subscripçáo, ou por, contratos com pessoas particulares, de que nảo ha falta, logo que se authorizem a cobrar a somma de seus deseinbolsos, e proporcionados lucros dos mesmos passageiros, e mais pessoas que se aproveitarem das obras, conforme o devido ajuste, e regulamento.

Pelo que respeita ás causas provenientes da falta d'instrucçáo, o remedio he dissipar as trevas da ignorancia, ordenando que todas as pessoas de ambos os: sexos saibảo ler, escrever, e contar; estabelecendo as instituiçōes, cuja falta a cima lastimei, e hum bom systema de estudos, como tambem fica indicado, honrando, e favorecendo os que se distinguirem, principalmente na Sciencia economica, que, sendo a mais importante, he a mais ignorada. Deviảo criar-se Cadeiras para ella em todas as partes, onde houvesse sufficiente numero de alumnos para frequenta-las; sem este preparatorio ninguem devêra matricular-se na Universidade, nem ser admittido a servir empregos publi-? cos de qualquer natureza que fossem. Mas todas estas: 


\section{(67)}

benéficas instituiçóes, 'e outras semelliantes, de pouco aproveitarăo, para espalhar os conhecimentos humanos sem a liberdade de pensar, e publicar os pensamen. tos por todos os meios conhecidos, principalmente o da imprensa. Esta preciosa liberdade habilita o Filosofo a instruir a hum tempo o genero humano todo nos mais reconditos lugares do Globo. Espalhando as luzes, como o Sol, descobre todas as manchas, e póe á vergonha os vellacos, e os empregados publicos prevaricadores, que por isso tremein della, pintando-a sempre com feias côres, como perturbadora do socego publico, e coin razăo; porque ella póe os espiritos em movimento, rasga as cortinas, e mascaras dos cortezãos, e as vendas que tapão os olhos aos Monarchas.; deixando penetrar a luz da verdade onde sem aquella liberdade ella jámais entrou. O povo, que lograr esta ventura, náo póde retrogradar; porque a mesma diffusăo das luzes descobre os perigos apemas appare$\mathrm{cem}$, e ao mesmo tempo os remedios. Sem ella o.Monarcha nảo póde conhecer o espirito publico do seu povo. He a cabra céga, que anda ás apalpadelas, sem vêr os precipicios, he hum piloto sem carta, nem bussola no Oceano.

\section{Segundo Quesito.}

Se a mesma Lavoura tem recebido progressivo augmento, de que tanto depende a prosperidade do Commercio desta Capital. E qual o motivo favoravel, ou desfavoravel a este respeito.

Que a Lavoura desta Capitanía tem recebido progressivo augmento, he huma verdade incontestavel, que se evidencêa pelos mappas do rendimento dos dizimos; 


\section{( 68$)$}

e de caảa hum dos outros impostos assentados sobre a producçăo, pelos da exportaçăo, e importaçăo, pela maior abundancia das commodidades da vida, e geral riqueza mais diffundida, e pelo visivel accrescimo da povoaçăo, e do preço das carnes, lenhas, e madeiras, symptomas que acompanhăo aquelle progresso.

As causas se descobrem principalmente: $I^{\circ}$ nas Leis, e providencias dadas a favor da liberdade do Commercio, como o Aviso de I I de Julho de I 798 ; que abolio as taxas do preço dos viveres, estendendo a esta Capitanía a disposiçăa do Alvará de 2 I de Fevereiro de I765. O Alvará de ro de Setembro deste tiltimo anno, que abolio as frotas, e restabeleceo a litberdade do Commercio interior destas Colonias. O de 4 de Fevereiro de 1773 , que ratificando aquella liberda'de, accrescentou a franqueza dos direitos a favor dos principaes productos nacionaes. $\mathrm{O}$ de 2 de Junho de 1766 , e 27 do mesmo mez de 1769 , quie concedêráo as franguias para se poder commerciar por escálas. $\mathrm{O}$ Aviso do $10^{\circ}$ de Julho de 1794 , que declarou estas puramente livres, como todo o.Commercio interior, para ninguem ser obrigado a faze-las contra sua vontade. O de I7 de Agosto de I 798 , e outras muitas Ordéns semelhantes, as quaes posto que náa tenhăo nunca tido inteira observancia; comtudo servírảo para adoçar as violencias dos executores fiscaes, e municipaes.

2. Na benéfica indifferença, com que se tem dissimulado a execuçấo das Leis contrarias áquella liberdade, taes como o Alvará de 14 de Outubro de I75 I, que prohibio a exportaçáo dos. escravos, prohibiçảo nảo sómente prejudicial, como todas, ao Corpo do Commercio, mas tambem á Agricultura, particularmente do tabaco, assucar, e farinhas; porque diminuindo o numero dos escravos, que se vảo buscar á Costa d'Afri- 
ca, (que he proporcionado á extracção que delles ha) diminue em consequencia o consumo dos generos, que se dăo por elles, on empregăo nesse goiro, que săo tabaco, mel, agoaardente, farinha, etc.; e diminuido o consumo diminue a produç̧ăo, e cultura délles.' 3

3.- Na situação, e fertilidade do terreno cortado de braços de mar, rios, e canaes abertos pela natureza; o que tem facilitado as communicaçóes, fazendo pouco dispendiosa a exportaçáo dos fructos 'da Lavoura, e a importação das materias, que servem ao consumo do Agricultor.

4. Na grande somma de capitaes estrangeiros, que tem entrado no paiz em mercadorias de toda a casta fiadas por longos prazos, a cujo respeito nos tem sido mui util a correspondencia das Naçốes ricas; onde os fundos pela sua superabundancia nāo achando beneficios proporcionados, refuem por muitas maneiras indirectas para liuma Colonia como esta, que pelas suas naturaes opportunidades offerece amplos beneficios a quaesquer capitaes, que se apresentem.

Auxiliada a Lavoura por estes, e semelhantes motivos, tem podido ir medrando pouco a pouco, náo por effeito dos regulamentos, que se fizerăo para favorece-la, mas a despeito delles, como com menos razäo o disse Smith da GräBertanha, Liv. I. Cap. 3, comparando-a com a natureza do enfermo, que auxiliada só dos principios vitaes vence ás vezes ao mesmo tempo a molestia, e os obstaculos dos remedios, que the applica a impericia do charlatăo. Os Estados, diz Joẫo Baptista Say no L. 'r." Cap. 33 . = prosperäo muitas vezes apezar das feridas, que recebem da măo de seus amigos, e de seus inimigos $=$ 


\section{TERCEIRO QUESITO.}

Se o Commercio soffre algum vexame. Qual elle seja. E se será conveniente ao mesmo Commercio particular desta Praça desopprimi-lo delle sem risco de outro maior damno.

Consistindo o Commercio desta Capitanía quasi todo na troca dos productos da Lavoura, tudo o que multiplica estes productos, multiplica a materia do Commercio; e por consequencia os lucros dos Commerciantes, e o que prejudica á cultura, deve prejudicar an Commercio. E como eu (se me năo engano) tenho feito vêr que a cultura soffre, fica evidente que o Commercio tambem ha de soffrer.

Năo he porém o vexame dos Negociantes tal como se pensa ordinariamente. Os encargos, que elles parecem soffrer, pelos pagarem pela sua mäo, vem recahir sobre os productor, e consumador. O Commerciante os lança em partida de despeza, e quem compra o genero paga regularmente todos os custos delle, incluidos no seu preço com a sobrecarga dos juros correspondentes á quaritia adiantada pelo Negociante. De outra sorte :este abandonaria a profissäo do Commercio; que he cosmopolita. Portanto semellantes encargos the saro ordinariannente indifferentes, ao menos depois de estabelecidos em forma que elle os possa prevêr antes de ultimar o negocio.

Os que porém não podem déixar de recahir sobre elle săo os que the encurtăo a'esfera de suas transacçóes tolhendo-lhe a liberdade de contratar , como sắo: as prohibiçóes de certas mercadorias, que posto sejăo sempre illudidas pelos contrabandistas, augmen- 
tắo com tudo o preço dellas pelo accrescimo do risco, diminuindo o consumo na mesma proporçăo quando năo săo de mero luxo de decoração; porque este, năo tendo outra base senăo a vaidade, mais se alimenta com o subido preço occasionado pela prolibição. Semelhantemente the prejudica a inhibiçâa de ccrtos portos, e de negociar com estrangeiros.

Náo săo porém desta natureza as licenças ordinarias que se exigem, para se poder vender e navegar; porque como nẳo se negăo a ninguem, huma vez que pague a competente dose, devem considerar-se como simples fintas. Bem assim as visitas, sêllos das pipas, lotaçóes; confrarias, registos; termos, listas, e todas as mais extorsóes, semelhantes que os Officiaes, encarregados de regular e favorecer o Commercio contra a vontade dos Commerciantes, se dignảo exigir scmpre debaixo do pretexto de algum serviço, que com tudo se dispensa commummente, se tem precedido a satisfaçăo da competente esportula. Quem acreditará que só a formalidade dos despachos para hum Navio poder dar: á vela para o Reino custe cento e tantos mil reis, e: os simples Bergantins empregados no giro interno mais. de cincoenta mil reis? Junte-se a isto o pezado encargo: de Capelláes, e Cirurgiôes, que os Mestres săo con-; strangidos a levar, e se verá quanto o nosso Commer-s cio anda mais gravado que o das outras Naçỏes.

De todos estes, e semelhantes encargos, se indemnisa - Negociante em deducçáo do preço da compra dos generos na mảo do Lavrador, ou accrescimo do preço da venda feita ao consumador. E como este accrescimo: nảo pode ter lugar nos generos desta Capitanía, por encontrarem na Europa a concurrencia de outros semelliantes, levados por Naçóes mais industriosas, e mais bem provídas de capitaes, nảo resta: aos Commercian-. 
tes outro meio de indemnisaçắo d'aquelles encargos, mais do que deduzir a sua importancia respectiva do preço das compras á custa do Cultivador. Por isso os arranjei na classe dos obstaculos da Lavoura.

Pelo que toca ao risco ponderado no Quesito. Como os vexames do Commercio estăo connexos com us das outras classes da sociedade, que tem o mesmo commum interesse, eu năo descubro inconveniente, ou risco alguin'em desopprimi-lo delles.

\section{Quarto Quesito.}

Se os differentes exames sobre a boa qualidade dos generos d'exportaçăo desta Colonia, e mais cautélas, que se praticăo a respeito dos mesmos generos, se podem considerar uteis, ou nocivos ao progresso do Commercio.

$\mathrm{Na}$ hypothesis do estado actual dos rendimentos reaes desta Capitanía, conforme os quaes pagảo contribuiçódes diversas o assucar, e tabaco, segundo as suas differentes qualidades, he forçoso examinarem-se os referidos generos, e'qualificarem-se, para se ver quanto cada hum ha de pagar. Supposta esta necessidade, e a de se recolhérem nos trapiches', segundo o actual systema d'arrecadaçáo dos dizimos, e' mais direitos, eu năo descubro inconveniente attendivel nos exames pratícados pela Meza da Inspeç̧ắo, năo obstante algumas. faltas inevitaveis 'em tudo o que he obra do homem. Elles săo feitos por huma Corporação existente para outros objectos, que năo he interessada em gravar, nem alliviar o imposto, nem sujeita ás paixóes do odio, te-mor, respeito, ou affeiçăo; pois qualifica o genero sem conhecer a quem pertence. I 
Hum Collegio de Negociantes, e Lavradores, que deve ser escollido a pluralidade de votos por aquella respeitavel Corporaçăo, parece ser o mais proprio, e competente Juiz para legalizar aquelles exames, que sendo assim authorizados previnem muitas questóes entre os collectados, e os administradores fiscaes.

O inconveniente da demora he facil de remediar, c nâo sería menor a que resultaría dos multiplicados pleitos, que deveriảo suscitar-se entre as partes logo que faltasse a confiança, e respeito, que naturalmente se tem para com os exames authenticados por huma Junta d'aquella natureza.

Por outra parte os Negociantes, e Lavradores, principalmente os que-habitáolugares distantes, guiados por aquella qualificaçăo, concluem mais facilmente os seus ajustes por cartas sem despezas de jornadas, agentes, e perdas de tempo, convencionando certo preço sobre os ferros da Inspecção. E esta pratica mostra a confiança, que a Meza tem merccido ao publico, que he o melhor Juiz do conceito dos empregados. Sem aquella qualificaçăo sería preciso que ou cada hum dos que pertendessem comprar fizesse seu exame particular com trabalho, e deterioração do genero, (que náo poderia deixar : de soffrer alteraçáo pelas repetidas exposiçóes ao ar, principalmente o tabaco) ou que elle se fiasse na palavra do vendedor; confiança, que daria. lugar a fraudes, e rixas; o que tudo se evita com aquella marca, ou titulo de abonaçấo a favor do genero, que o acredita; e dispóe o animo do comprador a entrar em ajuste pela confiança, que lhe inspira de näo ser logrado; scmelhantemente ás marcas postas pelos ensaiadores nas peças de ouro e prata, e aos signaes que distinguem os productos de certas Fabricas acreditadas. E considerada por este lado, vem aquel- 


\section{$(74)$}

la marca a ser hum instrumento de Commercio, que facilita as compras e vendas sem prejudicar a pessoa alguma, năo sendo acompanhada de coacçăo, e podendo os proprietarios do genero exporta-lo livremente, $\mathrm{c}$ vendê.lo por qualquer preço em livre convençăo.

$O$ que parece tirar toda a duvida sobre a utilidade de semelhantes marcas he, que năo ha ningưem que se nảo aprovcite dellas, podendo todos despreza-las a seur arbitrio. Os Lavradores igualmente, e os Negociantes mandảo pôr, sempre na lista de suas caixas os ferros que tiverẳo trabalho, a que se poupariảo; se julgassem a qualificaçăo da Meza inutil, ou nociva.

Com tudo devo confessar que se esta năo estivesse hoje organizada, e encarregada de outros objectos, eu nắo approvaria a sua creaçăo, só para aquelles exames, pelo perigo inherente a semelliantes Tribunaes de se erigirem em reguladores de Commercio, Agricultu$\mathrm{ra}, \mathrm{e}$ Artes, que náo podem deixar de soffrer todas as vezes que alguma Authoridade publica se ingere a governa-los, ingerencia quasi inevitavel para hum Tribunal de Commercio; porque lisongeando a vaidade na-: tural a homem de querer tudo regular segundo o proprio entendimento, a disfarça ao amor proprio debaixo do pretexto de deveres de officio com responsabilidade, năo lhe deixando perceber aquella verdade táo altamente proclamada pelos Economistas; que nảo ha senáo a intelligencia particular de cada Cidadăo, qué: possa regularmente vêr o que mais the convem no exercicio de sua industria, e que o que mais convem a cada hum he que imais convem ao publico, năo sendo o interesse deste senáo a somma dos interesses d'aquelles.

Pelo que respeital ás cawtelas lembradas no Quesito, respondo que en náo çonhieço senăo aquellàs sobre 
que tenho já exposto a minha opiniáo, e que em geral eu julgarei nocivas quaesquer outras formalid ades que possa haver, se nảo forem precisamente indis pensaveis para segurar a exactidảo das qualificaçóes.

Se com effeito as ha, deverăo reformar-se; sem que por esse abuso deva concluir-se que seja justo abolir a Meza que o tem tolerado. A nuaior parte dos obstaculos aos progressos da Lavoura, e Commercio desta Capitanía, que tenho observado, procede dos regulamentos, e posturas desse respeitavel Senado; e creio que neste ponto está de acordo comigo a voz do publico:- deverá por ventura dahi concluir-se que se deva abolir o Governo municipal?

\section{Quinto Quesito.}

Se o Lavrador desobrigado destes exames, e o Negociante na liberdade de convencionar-sei nos preços dos generos com o mesmo Laurador, promoveráa melhor seus reciprocos interesses.'

Pelo que respeita aos exames, fica respondido ao Quesito antecedente. Elles săo indispensaveis quanto ao assucar, e tabaco, yisto o actual śystéma dos nóssos impostos, que variando segundo as diversas qualidades destes generos, he forçoso examina-los para distinguilos, 'e qualifica-los : ' pois șem isso se năo podcrá saber que assucar he o que deverá pagar noventa réis de subsidio, e qual sessenta, nem que tabaco he o que se deverá exportar para a Europa. E como o Officio de S. Excellencia nos năo deixa a liberdade de discorrer fóra da hypothesis do estado actual dos rendimentos reaes, năo comprehendo como este Quesito possa em tal caso ser materia de queștảo, nem como haja quem pense 
que se podem escusar aquelles exames, permanecendo o mesmo systema d'imposiçóes. A náo ser isto eu os julgaria nocivos se fossem obrigatorios, e deixaria no arbitrio das partes o faze-los, ou omitti-los; porque se he para ellas hum beneficio, este se năo confere a quem o rejeita. E pelo que toca ás taxas, já näo pedece duvida que só a illimitada liberdade póde assignar a cada genero o seu preço natural, que he prccisamente o mais conforme ao verdadeiro interesse do Lavrador, e Consumador, e o unico que se confórma com a Justiça.

Esta verdade confirmada pela experiencia, que temos aqui observado, năo só tem sido sustentada por todos os Economistas, assim Phisiocratas, como Smithistas, mas he já hoje reconhecida até d'aquelles mesmos, que estăo ainda preoccupados do antigo systema exclusivo, como o famoso agronomo Young, que na Arithmetica politica, I. ${ }^{\mathrm{a}}$ parte, Cap. I 2, art. ${ }^{\circ}$ Liberdade dos preços, se explica assim = Deveria ter-se comprechendido que o effeito de huma taxa he destruir o "verdadeiro preço, para the substituir hum facticio; c huma administraçăo sábia deixará sempre as nerca"dorias, e mesmo os generos da primeira necessidade «á liberdade do Commercio, á concurrencia, que näo c conheça obstaculos. Ha cousa mais opposta á libercidade que negociar sobre huma cousa, năo com o c vendedor, mas com o Magistrado? Năo he violar a “ justiça dictar Leis arbitrarias sobre as convençő́es? "Que he huma ordenaçăo taxativa? He hum regulasi mento, que transtorna os direitos da Sociedade. Não " he do officio do homem público o intrometter-se no "Commercio; deve ser espectador tranquillo. ="

De todas as taxas dos preços a Lei do maximo parece a menos má, por ser igual para todos, e liber: 
tar o proprietario do despotico arbitrio dos Officiaes encarregados dessa terrivel authoridade. Com tudo esta Lei adoptada en França em 1793 foi reconhecida por huma das causas da decadencia, que experimentou n'aquelle tempo a indústria, e a Agricultura Franceza, como fez ver Mr. Simonde no L." 2 , Cap. 9: e os males que occasionou forăo tăo sensiveis, que a fizerảo logo revogar.

Felizmente a liberdade dos preços nos fó em fim concedida, e se acha apoiada com energicas providencias do Illustrissimo e Excellentissimo Senhor Conde da Ponte; que pela sua infatigavel actividade, penetraçăo, e luzes, nos pớe a cuberto de quaesquer violencias, que só poderiáo recear-se debaixo de outro Governo menos vigoroso, c providente.

Por isso julgo desnecessario fatigar mais a VV.SS. com as minhas prolixas declamaçóes, a que ponlıo em fim termo com a sincera protestaçăo de que a liberdade, com que tenho declarado as minhas opinióes contra alguns regulamentos desse preclarissimo Senado, năo provem de falta de respeito, que the he devido, e eu mui especialmente lhe consagro, mas tăo sómente da consideraçắo do dever, que me liga a expôr francamente toda a verdade, que julgo interessante ao publico, e Real serviço de S. A.'R. n'huma occasiäo, em que se digna ouvir-nos;' deixando vệr as suas paternaes intençóes de corrigir os abusos, que opprimem a Lavoura; e Commercio desta Capitanía. Em taes circumstancias o silencio sería hum crime, que me tornaria responsavel dos damnos occasionados por qua'.juer abuso', que deixasse de corrigir-se por falta de manifestaçä̀.

He por isto que eu julguei dever prestar-me promptamente á insịnuaçăo desse respeitavel Senado, apre- 


\section{$(78)$}

sentando-lhe os mois sentimentos tacs e quaes, persuadido de que elle prezará mais verdades nuas que lisonjas enfeitadas. Mas quando o fervor do meu zelo pelo bem de hum Povo, que sou obrigado a servir por officio, e a amar por gratidăo, me tenha seduzido, e precipitado n'algum excesso, espero da mesma benignidade, com que VV. SS. me lionráräo por huma carta táo lisongcira, a indulgencia dos meus crros em attençăo ao bom principio, de que procedem. 1807.

Deos guarde a VV. SS. Bahia 28. de Maio de IIl. mos S. res do Senado da Camara.

Foäo Roiz de Brito.

\section{CARTA II. \\ Senbores do Senado.}

Chegou ás minhas mäos ell 23 de Maio a carta, com que VV. SS, me quizeräo tanto honrar, com a data de I 6 do meșino mez, e recebia quando nem as forças do espirito, nẹm as do corpo me permittiăo dar a VV. SS, satisfaçăo, năa digo tal, qual de mim esperaväo; tạl, qual cu dẹsejava; mas qualquer que ella fosse, para de algum modo satisfazer ao natural desejo de contribuir para o bem deste Paiz, a que manifestamente se dirigem os Queșitos de S. A. R. o Principe Regente Nosso Senhor, a carta do Excellentissimo Senhor Governador, que recebi por copia, e a de VV. SS curto : achava-me de 


\section{(79) -}

cama com hum caustićo aberto no ventre, e cm estado de me năo poder nem virar. Em nenhunas outras circunstancias poderia eu responder peior scbre tantas, e tăo differentes materias: sirva-me pois isto de escusa se näo preenclier em objecto de tanta ponderaçăo as grandes idéas, que VV. SS. se tem querido formar das minhas luzes e talentos. He tempe de entrarmos em materia.

Pelo primeiro Quesito se pertende saber se se reconhece nesta Cidade alguma causa oppressiva contra a Lavoura; qual seja esta causa, e o meio de ella se evitar.

Nảo he de ordinario nas Côrtes, e grandes Cidades seritir-se os males a que a Lavoura está sujeita, e por tanto nada de mais natúral, e cónforme á razăo do que virem 'VV. SS. buscar ao campo informaçóes do que soffrem os que o cultivảo.

Nas Cidades ouvé-se fallar da Lavoura; e quando muito aquelles que mais interessäo nella, applicandose ao estudo "das caúsas 'que a pódem promover, ou atrazar, chiegão a descobrir nas Leis, e Regimentos, que the dizem réspeito, as causas favoraveis ou desfavoraveis ao seu progresso; e posto que lhes pareça estranho, começarei por estabelecer como principio, que teńho por muito verdadeiro; 'que todas as Leis, Regimentos, Bandos, Posturas de Camara, quando elles sahiem do recinto das Cidades, näo servem senăo a li songear a vaidade dos que governáá; a obstar ao progresso da Lavoura,' e Massa das producçóes, em que consiste a verdadeira riquéza ; a semear a discordia en-' tre os Lavradores; e em fim só se fazem para serem illudidas, é esquecidas em pouco tempo.

Désta regra geral, a que cónheço só duas, ou tres excepçöes, lembrarei huma recontiecida por ne- 


\section{( 80$)$}

cessaria entre nós desde o anno de 1609 , quando se deo Regimento á Relaçăo desta Cidade: quero fallar तa Lei feita para regular as plantaçб́es, e conservar os bosques, e matas. Nella se ordena no tt. da ordem, que o Governador do Estado do Brazil ha de ter nas cousas de justiça e Relaçảo = que terá particular cuidado de prever sobre as lenhas, e madeiras, que se năo corten, nem queimem para fazer roças, ou para outras cousas, em partes que se possäo escusar; por quanto so!ı informado que em algumas Capitanías do dito estado havia muita falta da dita lenha, e madeiras, e pelo tempo em diante haveria muito maior, o que será causa de nắo poderem fazer mais Engenhos, e de os que agora ha deixarem de moer = ora se ha I98 annos, quando apenas este Paiz tinha sahido da barbaridade, havia já falta de lenha, e madeiras; se essa falta então deo motivo a liuma tăo sabia, e próvida Lei a favor da Lavoura, e construcçóes de todo o genero, principalmente navaes, que tanto auxiliảo a agricultura, que diremos do estado presente? Se aquella Lei, que na verdade contraría em parte á liberdade de alguns proprietarios, a beneficio de tantos, nảo teve cumprimento, que deveremos esperar de novas, que talvez năo tenhắo a sabedoria d'aquella?

Porque motivo, diz hum Escritor bem moderno; J. B. Say, se prescreveria a hum productor de fabricar a sua mercadoria de tal modo, antes que de tal cutró? Será para que ella se venda melhor? Ah! E quem he mais interessado nisso do que elle? Se agora que os assucares mascavados vendem os brancos viesse huma Lei, que obrigasse aos Senhores de Engenho a fazer só assucar branco, sería ella a beneficio da Lavoura? Certamente qué nåo. Eu tenho adiante dos olhos huma vasta extensáo de terreno, em o qual mais 


\section{( $8 \mathrm{i})$}

que em nenhum outro se deveria dár cumprimento a Leı citada; năo só por ter na sua redondeza mais de vinte Engenhos, por estar cercado de rios navegaveis , mas muito principalmente por produzir as melhores lenhas de decoada, sem a qual soffre infinito o fabrico do assucar, que he, e será sempre o ramo mais importante da Lavoura deste Paiz, o vejo-o inteiramente devastado, e reduzido a campo, ou a channeca, depois de ter sido povoado de muito boas matas; e para que? Para nelle se ter plantado algum milho, e arroz; que sem grande incommodo de quem se dá a esse genero de cultura, se pudéra ter plantado a huma legoa : que digo? A hum quarto de legoa distante da borda d'agoa. Assim parece exorbitantemente proyado que as Leis, e Regimentos, quando-restringem a liberdade dos proprietarios, ainda fazendo huma das mais justas, e direi ainda necessarias excepçốes do direito de poder cada hum fazer o que the parecer, e melhor the convier, sắo sempre illudidas, e de nenhum effeito.

Mais, diz o mesmo Author citado, os Regimentos săo muito bons, e uteis todas as vezes, que elles previnem a fraude, huma pratica, que evidentemente offende as outras producçóes, ou publica segurança : mas dî-lo como huma objecçăo, a que elle responde muito satisfactoriamente. Náo he preciso que hum Fabricante possa annunciar debaixo da sua marca, ou carimbo, huma qualidade superior á que elle fabríca : a sua fidelidade interessa ao consumador indigena, a quem o Governo deve a sua protecçăo, interessa ao Commercio que a Naçảo faz para fora, porque o estrangeiro cessa bem depressa de dirigir-se a huma Naçăo que o engana ; mas depois desta, c outras reflexôes, elle conclue dizendo : basta isto, creio eu, para indicar até a que ponto estender-se a intervençáo util do Governo. Elle deve 


\section{$(82)$}

certificar a verdade da marca, ou carimbo, e năo se embaraçar de nada, que diz respeito á producçăo. Eu queria ainda, continúa o mesmo Author, que se năo perdesse de vista que esta intervençăo, mesmo util, he hum mal; he hum mal, porque ella immediatamente vexa e atormenta os particulares, e depois porque he custosa, seja para o povo, quando a intervençảo do Governo he gratuita, quero dizer, quando ella se faz á custa do Thesouro publico ( tal he entre nós a que c Governo exerce na qualificaçăo do assucar, e tabaco) seja para o consumador, quando se tirăo as despezas por hum imposto sobre a mercadoria, como succede nas tulhas dessa Cidade: ora o encarecimento, que sempre se segue, he para o consumador do paiz huma carga de mais, e para o estrangeiro hum motivo de exclusăo. Se a intervenção do Governo he hum mal, continúa o uesmo Author, hum bom Governo a fará tăo raras vezes que lhe for possivel; năo garantirá as qualidades das mercadorias, sobre as quaes sería menos facil enganar o comprador, que he o Governo mesmo; nảo garantirá aquellas; cuja qualidade năo lıe susceptivel de ser verificada pelos seus agentes; porque o Governo tem sempre a infelicidade de ser obrigado o contar com a negligencia, com a incapacidade, e com as culpaveis condescendencias dos que elle emprega.

A's vezes, ajunto eu, he preciso ainda contar com o interesse particular d'ąquelles mesmos, a quem o Governo commette os exames; quando os agentes săoJuizes, e parte em causa propria, como acontece com o assucar, e tabaco entre nos; ás vezcs com o dolo, e com o peculato, como he notorio que tem acontecido com o tabaco; o que acontecendo, faz que os Regimentos, que já vimos serem hum mal, venhăo a ser hum mal lamentavel, e sem remedio, quando o Governo. 
que o determina náo se chega a convencer da sua realidade: e quantas vezes năo toma elle muito traballo, e faz muita despeza para augmentar o mal, que elle procura remediar?

Antes de entrar a tratar dos dois unicos estabelecimentos, que se encontráo ria Bahia, e que, segundo os meus principios, se elles năa săo os da -mais 'să economia politica, diametralmente se oppóem ao augmento das producçỏes; isto he, da Meza da Inspecçảo, e do Celleiro da Cidade: eu desejára lembrar que nada mais se tem opposto á prosperidade da Lavoura de păo, de que nos sustentamos, do que os obstaculos, que se tem até agora posto, segundo a fanthasia dós que nos tem governado, á liberdade do Commercio, que fazem sejăo os productores elles mesmos; sejăo os que compráo a farinha aqui, para vender acola.

Mais hum genero he necessario, como o de que tratamos, menos o Governo se deve embaraçar da sua producção, seja agriconomica, seja mercantil: e direi ainda mais, menos convem que elle faça Regimentos, ou tome medidas para que elle se venda por menos do que realmente custa a fabricar, e a transportar, quero dizer, a baixo do seu preço natural.

He muito ordinario ouvir aos que nada produzem; e ainda áquelles, que se dão ao genero de cultura mais lucrativo, que he o da cana, queixarem-se da carestia da farinha, que talvez he o que menos convem a cultivar, e fabricar nesta Capitanía, de quem lhes faz o grande bem de comprar aqui onde ella se acha em abundancia, para vender onde ella he rara, e necessaria ; como se os Lavradores de pão devessem sericonsiderados como pessoas de inferior qualidade á sua, a quem nunca fosse licito de tirar partido do seu suor, e industria; como se o Commerciante de farinhas, ordi- 


\section{(84)}

nariamente aborrecido, quando elle he considerado por Smith como o mais favoravel á abundancia depois do productor, devesse igualmente armar as suas em- barcaçóes de graça, e continuar n'hum genero d'especulaçẳo; que lhe désse perda, para utilidade dos consumadores. Que as farinhas se não exportem para fóra. da Capitanía clamão todos, năo se queixando nunca das que para ella entrảo de fóra; como se a que se exporta saia de graça, ou nảo traga em retorno com que animar, e fomentar a sua mesma cultura. Eu attribuo em grande parte a abundancia, que temos tido ha quatro para cinco annos, á fome que teve Pernambuco por esse mesmo tempo, para onde se exportou, a despeito dos obstaculos do Governo interino, e do seguinte, toda quanta foi precisa para que nảo morressem os seus habitantes á fome, e á necessidade; c: a- só lęmbrança de que os que entä́o nadavăo na abundancia negavão aos seus vizinhos, aos seus compatriotas, e aos seus mesmos irmảos, huma parte do que lhes.scbrava me causa ainda horror, e faz aborrecer tudes esses vexames, e prohibiçóes, que por fortuna vem a ter o pertendido, e desejado effeito.

Nảo se dirá que eu fallo assim, porque nảo péze sobre mim o sustento de huma numerosa familia, ou porque seja Lavrador de Mandioca: sustento para cima de duzentas e cincoenta pessoas: custa-me semanariamente o seu sustento, segunido os preçes actuaes da farinha, de trinta e seis a quarenta mil réis; - e não planto hum só pé de Mandioca, para não calirir no absurdo de renunciar a melhor cultura do Paiz pela peior que nelle ha, e para não obstar a huma por outra cultura, e complicar trabalhos de natureza differente; e sempre que desembolso o necessario para o pảo da miaha familia; quando elle está: caro; assento em empresa 


\section{$(85)$}

tar o excedente do seu preço ordinario a quem o traballha; e ainda me năo succedeo deixar de receber com. usura semelhantes avanços. Fui testemunha ha anno e meio, estando na povoaçăo de Nazareth, da desgraçada sorte do cultivador de Mandioca; ella the năo dava entåo para pagar o transporte da farinha; e depois. de me convencer da sua miseria, e infelicidade, poderia eu desejar a continuaçăo della? e dizer o contrario do que tenho dito?

Passemos a materia mais connexa com aquella, de que acabamos de fallar; e VV. SS. preveräo logo que eu vou a tratar das Tulhas. Tedos sabem que ellas foráo devidas á piedade, c zelo mais religioso que politico do Senhor D. Rodrigo Jcsé de Menezes; que nenhuma Lei, ou Ordem Regia, tem por ora authorizado o Imposto que pagáo os Lavradores, e Commerciantes de farinha, que sobre isso se vem forçados a metter n'aquella unica casa, e a fazer sahir por aquella só porta toda a farinha de que se deva sustentar a Capital do Paiz, e parte dos seus Reconcavos: a governar-se pelos arbitrios bons, ou máos dos Governadores, que tem succedido ao que as creou, e que até agora se năo tem feito conhecer, e publicar; parando elle sómente nas máos d'aquelles mẹsmos, a quem se commette a sua execução. Que bem poderia vir de hum tal estabelecimento? O que he publico, e notorio. Depois de sobrecarregar-se o Celleiro público de huma Administraçắ, com que náo podia, o na verdade pequeno Imposto que se poz sobre a farinha, máo por não ser legal, e pelas razóes que abaixo direi, afugentcuse com elle tanto o Lavrador, como o transportador de farinhas, para se náo sujeitarem, valha a verdade, a penas arbitrarias, e a condemnaçóes exorbitantes do duplo do Imposto, logo que se julgão culpados pelos. 


\section{(86)}

Administradores das Tulhas, para năo ficarem retidos, e fazerem sempre huma venda em retalho: para năo pagar em excessivos alugueis de saccos, e carissimas conducçóes aos Agentes das Tulhas, que para isso tem escravos seus, exercitando assim sobre aquelles miseraveis o mais arbitrario, e tyrannico despotismo, a que nảo podem deixar de acquiescer; pois que de outro modo se lhes difficultaria a extracçã̃o; em fim para năo ficarem obrigados a pagar muitas vezes năo só o Imposto, que se percebe nas Tulhas das farinhas, que nảo enträo nellas, e se transportăo para fóra; mas ainda mais, o qué com difficuldade se acreditará, para nảo pagar o Imposto por aquellas, que nem ao menos trazem ao porto: tem chegado a tanto a injustiça, que se tem obrigado a carregadores, cujas embarcaçóes seriảo capazes de transportar, por exemplo, tres mil alqueires de farinha, e que nảo chegárảo á Bahia senảo com mil, a pagar o Imposto á Tulha, năo pelo que traziăo, mas sim pelo que podiăo trazer.

Tein sobre tudo de máo a Tulha de se perceber esse Imposto muito proximo da producçắo, que he justamente o contrario do que devia acontecer. Mas dir-se-ha: a Tulha he o Celleiro público, e o Imposto que nella se percebe he destinado para huma obra pia. Quanto aos Celleiros năo săo reconhecidos pelos bons Economistas como o meio de fazer abaixar o preço do páo, nem de evitar a fome; o que pelo contrario se consegue, he opiniăo geral por huma plena liberdade do Commercio dos generos, que os enchem; e quanto á obra pia, nảo se devem fazer cousas más, para que dellas venlaảo boas; nả̉o se deve vexar, e atormentar a tantos, para soccorrer a poucos miseraveis, que fora do dever do Governo, e das casas de Misericordia soccorrer. A Tulha he hum bem, porque he huma 
segurança para que a Cidade náo soffra em tempo de ventos contrarios, dirăo outros. Quanto á primeira parte, se he hum bem fique para quem se quizer aproveitar delle; năo se obrigando nunca o transportador de farinhas a servir-se della; nảo se embaraçando no porto as vendas'em grosso por baldeação, que săo as que dắo mais actividade ao Commercio dos grảos, e que convem manter, e năo destruir; perceba-se embora esse, ou outro maior Imposto, o mais longe que for possivel da producçăo, quero dizer, do consumador, que achar commodo em comprar a farinha da Tulha, e nảo de quem a trouxe para ella, como agora se pratíca; e obrando assim, he de esperar que haja maior cultura, maior concurso, em consequencia do que só póde vir a abundancia, e barateza; quanto ao abrigo nos tempos contrarios, as estaçóes, os temporaes, forăo ha tres seculos os mesmos que săo agora, e a Bahia nảo soffreo durante elles mais do que soffre presentemente, e creio se póde avançar sem faltar á verdade que o Molhe, ou Caldeira da Ribeira tem sido mais proveitosa ao provisionamento da Cidade que o estabelecimento, e regulamento das Tulhas; o que se assim he, está achado o remedio mais proprio parar curar o mal.

Immediatamente ás. Tulhas direi ainda alguma cousa sobre duas outras causas, que se oppóem ao progresso da Lavoura, e que vexăo os Fabricantes de farinha: a primeira he a praga dos Capităes Móres, que recrutando sempre que se pede gente para a Praça, o que he frequente, preferem os que trazem farinhas ao mercado, que de ordinario sáo os mesmos que cultivăo a Mandioca. He cbservaçăo, que. constantemente tenho feito, que sempre que se fazem rccrutas, encarece a farinlia; encarece năo por que haja monos, mas por que vem menos ao mercado. O remedio a este mal, que 


\section{(88)}

tambem näo he pequeno, parece que estaria em izentar os Districtos, ou Termos, que se dảo a esse genero de cultura, de semelhante onus; de fazer sómente nas Villas ou Cidades, onde de ordinario se encontrăo braços ociosos, a gente necessaria para o serviço, e defeza da Capitanía. A outra causa contraria ao Commercio, e producção do pão, além das posturas das Camaras, que lhes dizem respeito, e de que já fallei, he o flagello dos Almotacés. Qualquer destes pequinos Juizes he capaz de fazer morrer á fome, náo digo huma familia, mas huma grande extensão de Paiz, que se vê na necessidade de comprar farinhas, prohibindo, como acontece em Maragogipi, a sua sahida, ou atravassando-a, para the dar differente curso do ordinario: e tudo isto fazem pretextando a utilidade publica, e a segurança da sustentaçáo da Villa, que menos periga, porque nella se faz o mercado etc. etc. etc.

Quando nos capacitaremos nós de huma verdade, que devemos ás meditaçốes de Smith, e he, que huma das principaes causas da fome tem sempre sido o mesmo cuidado, que se tem tomado para a afugentar?

Eu vou agora passar a outro, e maior obstaculo, que se encontra na Cidade da Bahia, contrario ao progresso das producçóes, que se exportảo, contrario aos interesses do Commercio, contrario á liberdade dos que as produzem, isto he, da Meza da .Inspecçăo do assucar, do tabaco, do algodăo. A Meza da Inspecçắo foi estabelecida com o fim, năo digo de limitar a Lavoura, se todavia isso devia seguir-se de hum semelhante estabelecimento, mas com o de taxar, e qualificar os productos da Lavoura do assucar, e do tabaco; veio depois a Inspecçáo do algodáo; e admira muito que seja este novo encargo de tăo recente data. Tratarei sómente da taxa, porque a respeito da qualificação já creio 


\section{(89)}

ter dito assaz. A taxa, cujo nome sómente causaria hoje em dia horror, se se pertendesse estabelecer de novo, deixou de ter effeito porque era absurda, e não tardou o Governo, assim como os Commerciantes, e Lavradores, a reconhecer o quanto ella era contraria aos-respectivos interesses de cada hum Seguio-se pois o que necessariamente se devia seguir: infraç̧ăo da Lei, e tolerancia de poder fazer contra ella cada hum o que melhor the conviesse. E com effeito como se poderia sustentar aquella Lei, que estabelecendo o preço ao assucar, ou taxando-o, nảo taxava ao mesmo tempo o dos generos necessarios á sua cultura e fabrico? Sé pois năo convem a hum sabio Governo o intrometter-se com a producçáo qualificando os generos, cuja bondade elle se năo pode assegurar: se certo de que todos os Regimentos, que elle fizer para intervir na producçăo, deverăo ter a mesina sorte da Lei da taxa do assucar, parece que tambem deve seguir-se que a Mezá da Irspecçăo, năo existindo a taxa, năo presta hoje para nada; e que fazendo-a ainda recordar, nenhuma outra. medida, qualquer que elta seja;: poderá corrigir a sua maldade que a de fazer desapparecer até a memoria da sua existencia do corpo das nossas Leis, e Regimentos:

O que tenho dito bastará, creio eu, para fixar: a opiniảo de:VV. SS. sobre a utilidade, ou inutilidade da Meza da Inspecção; mas como nunca faltăo protectores para as cousas ainda as mais detestaveis, e que ás vezes contrariảo: 0 interesse daquelles mesmos, que as protegem, eu vou entrar em maior exame sobre as vantagens, ou desavantagens que vem; ou podem vir, tanto á Lavoura, como ao Commercio; da Meza da: Inspéç̧ăo: 'nella, já toquei de passagem, todos os Juizes săo Juizes, e partes en causa propria; huns negocêão em assucar, e sempre lhes con- 


\section{(96)}

vem compra-lo por menosi do que realmente custa a produzir; outros, que digo ? hum só pune pela Lavoura, porque the convem que o assucar se repute bem; na contestaçáo de dous contra hum he muito natural qrie este fique veńcido; ou supplantado; e sobre que sé disputa!-Sobre cousas eñ que neuhum póde julgar corn perfeitó conlrecimento de causa, pois yue julgão do hum generd, que tem certo valor intrinseco, i e este se náo conhece por caracteres externos; mas sim pelos internos, isto he, pelo ensaio, ou pela escumadeira. E depois de muita discussta, se a póde haver, inspectando-se em huma manhä, ou antes em duas horas, de quatrocentas a quinhentas anostras de assucar, para que, serve semelhante qualificaçảo? Nảo importa ao Commerciante o ferrete, ou carimbo que a caixa leva, importa-lhe ver se o genero vale, o que se pecte por elle; a despeito de todos os contrastes, o conyprador, e vendedor fazem ao contrato de compra, venda as Leis que Ihes parece. He sabido que já em Lisboa, näo digo em Hamburgo, em Genova etc. se nấo faz o menor caso das marcas da Inspecçáo; que á vista das amostras, e dos numeros que indicáa os; pezos; se concluem os mercados; no caso porém de duvida recorre-se a melhores Juizes, aos confeiteiros cada comprador he pois ihum Inspector de assucar; assim como na Bahia se faz de cada Negociante, de cada Senhor de Engenho hum, nảo para decidir da sua fazenda sómente, de que cada hum póde fazer que bem lhe parecer, mas da deitantos, que nảo: acquiescendo ąos seus julgados, ; ou jülgando-se lesados, nenhum: outro recurso lhes resta senăo de implorarnaos seus mesmos Juizés que reformem as suas Sentenças, e posto que semelhantes reformas nảo lisongêem mutito a vaidade dos julgadores ${ }^{2}$ devemos confessa-lo paral credito 


\section{(9x)}

đelles; que raios as pedem, que năo sejåo attendidos : tảo arbitrarios e incertos săo os seus julgados : façắo fé os mesmos livros da Inspecçáo. Mas quảo poucos estảo no caso de pedirem semelhantes reformas! $O$. Senhor de Engenho não, porque reșide fóra, e nào the convindo para isso ter Procuraldores effectivos na Cida de, săo os seus assistentes, e os que recebem as suas caixas em pagamentos, os que poderiạo requere-las ; e săo estes os que mais se interessäo em que se năo fação taes reformas. Os Negociantes pejajo-se de as pedir, quando por acaso se julgia lesados, se o na fazem, calculando que tem mais a perder que a ganhar nas alteraçóes que se fizerem na Męza da Inspecçăo, onde elles preponderâo. Desculpa-se sempre a Meza em taes casos com a necessaria, e indispensavel conr fusăo das amostras; nada menos quer ella dizer con isto que náo póde deixar de dar a Pedro o que he dé Paulo; e poderiáo soldar-se em alguma parte do mundo civalisado Juizes, que assim julgassem !

Pertende muita gente, que mais năo alcança : primeiro, que a Inspeç̧ăo he favorayel á cultura porque 2 promove , b obrigando alas Senhores de Engenlo, $\mathrm{c}$ Lavradores de rtabaco a nielhorarem os Iseus generos: segundo:; que sem ella daveria hum grande embaraço nas: vendas; não concordando nunca o vendedor,cem - comprador na qualidade do genera a terceiro themem outros que $\mathrm{cm}$ tempós desgraç九tos se nă

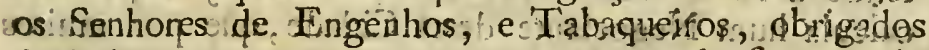
a vénder os seus: generos; para menos do ferro ; năo éxistindó a Meza da Inspecçr̃o A ttido vou responder. Já VV. SS. preverảo que eu inăo entendo que se faça bem a alguem, obrigando-o; que duvido muito que por esse meio se consiga algum dia o que seritender. ICada hum deve ser senhor de fazer o que mais 


\section{(92)}

the convier; e que mais lhe convier he o que mais convem ao Estado, e ao Soberano, que tem partilha em todos os seus lucros, e interesses. Se os assucares mascavados continuaren, como parece, a serem preferidos aos brancos; se năo convier de todo fábricar esta qualidade de assucar, no que imitaremos as Naçóes que nos avançăa em cultura, e em conhecimentos dos seus proprios interesses, para que servirá entảo a Meza da Inspecçăo ? Como promoverá entä́o a Agricultura ? Nem ao menos like restará nesse caso o officio, que ella exerce presentemente, e que parece mais necessario, officio que poderá năo custar nada ao Governo, custando agora tanto, quero dizer, determinar qual he o assucar branco, qual he o mascavado; e nenhum Lavrador de cana, ou Senhor de Engenho ha, que duvide que sendo essa determinaçáo necessaria para o pagamento dos dizimos, e direitos Reaes, ainda até ágora se năo sabe verdadeiramente na Meza da Inspecção qual he a raia, ou ponto fixo, que separe o assucar branco do mascavado.:Agora que a Inspecçăo se tem visto ameaçada de pagar ao Commercio todas as differenças, em que os seus julgados se -afastarem da verdade a favor do Agricultor; assegura-se ella, rebaixando sempre na qualidade do genero, e por consequencia no preço, que estabelece; no que se tem havido alguma excepçăo, foi só tna safra pàssada, e obrando assim, o que he bem natural, pertende a Meza obrar sem dolo, e com justiça! Ora calcula hum Negociante desta Cidade, que por muitos annos maneou os dizimos do assucar, de que devia bem conhecer a producçăo, que tirando a Meża da Inspecçăo hum só t tostáo sobre arroba de assucar, distrahiria da sua industria, é cultura annualmente, de oitenta a noventa contos de reis; em mais pudera eu avaliar por experiencia propria o mal que ella faz á 


\section{(93)}

Agricultura, rebaixando nas qualidades de assucąr, c fundando-se no seu julgado o Commercio, quando trata de o pagar, em que ainda considero huma verdadeira taxa. Ora se isto he verdade, como se poderá pertender que a Meza da Inspeç̧a fomente a Lavoura? Ella ainda the distrahe por omissăo fundos muito mais importantes. "Aconteceo-me a mim mesma, na passada safra, perder em huma grande partida de caixas de trezentos a quatro centos mil reis na differença; que houve em poucos dias de preço a preço; e porque? Porque a minha mercadoria näo era vendavel antes de passar pelo contrastè da Inspeç̧ăo, e por sua negligencịa, com que ;já disse, se deve, sempre contar, se demorou por mais de quinze dias a qualificaçăo; de que valeó pois toda a minha actividade, suor, e pressa para aproveitar $\mathbf{0}$ preço de entáo, se tudo foi malogrado por causas, de que nảo devia depender?

Iguaes queixas i pode e deve fazer o Commercio, ainda que o considero de melhor condiçáo que a Lavoura ; e posto que tenha a vantagem de colher sempre beneficio todas as vezes que a Inspecçăo rebaixa na qualidade do genero, que elle carrega, quantas vezes elle năo he vexado, e altormentado por ella ? Quer expedir hoje o seu navio: tem no trapiche a carga que o abarrote, 'e năo o pode fazer, senảo quando ella 0 inspectar; e da demora de hum só dia the vem muitas vezes considéraveis prejuizos: tenho mesmo ouvido queixarem-se de novos impostos sobre a navegaçắo, estabelecidos sem a Regia authoridade, e que se estäo percebendo, com grave prejuizo do Commercio, e dos direitos de Soberania, contra quem se: tem animado a attentar; e tudo se the tem tolerado; porque infelizmente ha poucos, que se animem a dizer a verdade nua, e crua, ainda quando della lhes năo pode vir 


\section{( 9.4 )}

mal; e que fará pódéndo vir, como viria aos Commerciantes, sujeitos a mil respeitos á Meza da Inspecçắo!

Quanto ao pertendido: embaraço, que póde haver na venda do assucar, năo havendo quem o aquilate, nenhuma objecça me parece nem mais frivola, nem menos attendivel: Compra-se, e vende-se tudo que faz - objecto do Commercio; a avença das partes, e sem que haja quenr instrua o comprador, e só se deve fazer o contrario na venda do assucar, e do tabaco? Achăa-se inspectores a cada çanto: briga-se mesmo para ser onde aprenderia elles o que he preciso jaip pregucher bem o-seuministerio ? O Senhor de Engrentios nas suas officinas, os Negociantes na praça, e trapiches: ora pois que elles se achảo a cada canto, scjảo tantos os inspectores quaintos săo os Senhores de Engenhos, e Negociantes: deixe-se a cada hum fazer a respeito da qualidade o mesmo que estáo fazendo a respeito do preço; e dahi náo virá inconveniente algum; quero dizer, ponha o Senhor de Engenho na cabeça das suas caixas o ferrete, ou carimbo; que ellas : merecem; fique obrigado pelo seu proprio juizo a pagar os direitos ao Soberano; e como na he de esperar que clle entáo chame bránco ao assucar mascavado, - nảo virá dahi dimi an çằo al guma das rendas, muíto principalniente percebentose ellas, como agora se percebem, isto he, pelo decimo da importancia das vetidas. Se ol Negociante vir que o Senhor de Engenho he desarrazoado nas silas pertençoes', quem melhor do que elle o prote obrigar a chegar-se á razảo, é á verdade, nato the compravido a sua mercadoria ? Esișto só parece tera cóntín si o caso de duivida entre o crédor, e o dẹvador ; màs entăo nảo cónviria mais que a ambos se escolliessem arbitros para decidirem summariamente semethantes pleitos? 


\section{(95)}

Quanto á ultima objecçăo $;$ direi que vendendć-se actualmente o assucar além da taxa, por que razăo năo se venderá elle por menos della nos tempos desgraçadoș? Quie Lei justa poderá protiibir ao. Senhor de Engenho, que năo tem outro recurso, de sácrificar on seu gènero á sua necessidade; ao comprador de dar por hum genero, que năotem valor, aquillo que elle puder dar sem grande risco de - perder; embaraçando-lhe assim até a csperança: do ganho ; que só o póde excitar?

Eu não acabára . nunca y se houvesse: de / lhes dizer túdo quanto me occorre contra este, semellantes estabelecimentos; mas tärdé 'começo a perceber que já tenho respondido ao quarto e quinto Quesito, sem ter nada dito do segundo, te terceiro; o que talvez, se năo yem da ordem , en que elles se achäo, rvem, da connexảo das materiạs, ou da 'pouca ordem das mesmas idéas; se dahi rem, como creio, he curto o tempo para a ás pôt em melhôr digestắo.

O i segundo Quesito procura saber se a Lavoura tem rećbido progressivo augmento, de que tanto depende a prosperidade do Commercio da Capital; ; e qual o motivo favoravel, ou desfavoravel, a este respei-

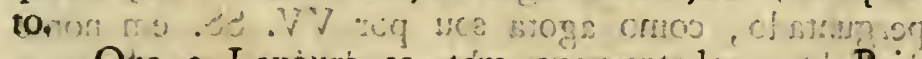

Que : Lavoura se : tém augmentado neste Paiz parece indubitavel, a despeito das causas já lembradas; que tem retardado o seu progresso, (e prosperidade; e se eu me năo enganei;, pondo entre ellas toda a interyençăo, do Governo, estabeleọndo Leis , 'Le' Regimentos para as favorecer, devo, para ser consequente, fazer votos, e ragar a $\mathrm{VV}$. SS is para que imprequem a Sua Alteża Real que a abandone, e esqueça; que será esse ${ }^{\top}$ meio mais seguro della prosperar, e e com ella o Commercio; que ihe dará novós allentos: De 


\section{(96)}

mais, quem melhor que o Governo da Capitanía póde julgar do progresso, ou diminuiçăo da Lavoura della? Elle; que quando náo tivesse outros Registos em seu poder, tem o dos dizimos, e se elles tem crescido, como he publico, e notorio, tem, á proporçăa do seu accrescimo, decuplado a massa das producçóes do Paiz.

Quanto ao terceiro Quesito, respondáo por si os Commerciantes: élles melhor do que eu, e do que ninguem, conhecem os seús interesses; e já de passagem. toquei o que sentia a seu respeito.

-Tenho a consciencialde ter entretido por mais tempo do que devêra : VV. SS., e estou persuadido que o tenho feito sem proveito: para porém me năo afastar do que se me recommenda em ultimo lugar, e năo dar algum systema novo, e'ímaginario, eu devêra parar aqui;; bem persuadido porém de huma parte das paţernąes intençóes ;ie bons desejos do Principe Regente Nosso Senhor, sobejamente manifestados pelos Quesitos que fazem o objecto desta longa Epistola, e de outra parte que sendo do dever de todo o Cidadáo pacifico réspcitar e obedecer ás Léis, por más que ellas sejão, está elle obrigado a dizer sobre ellas; sendo perguntado, como agora sou por VV. SS. em nome do Soberano, que entender : tudo: isto me ob́riga a accrescentar ainda o que julgo se póderia fazer, por que já se tem feito para augmentar as producçóes do Paiz; sem prejuizo das rendas; reaes.

- fl Sua Alteza Real parece estar contente com as actuaes, e mostra bem vontade de as augmentar; porque inţeressa que este Paiz se eńriqueça; para o conseguir pois, parece que os meios mais apropriados vem todos indicados no Cap. 40 do 'Tratado de Economia politica de J. B. Say, a que me reportára se a sua obrá 


\section{(97)}

andasse pelas mäos de todos. Elles consistem 'em fazer com que as propriedades, e pessoas tenhảo a maior segurança possivel, isto he, cm melhorar o Codigo das Leis, e em encurtar os processos; e diria ainda em năo mandar para as Colonias senáo Magistrados de conhecida probidade, e inteireza, e intelligencia de fazer tudo quanto fòr possivel, para que a massa das luzes, e conhecimentos se augmente; de procurar que venhäo para este Paiz as plantas, de que tem vindo grande utilidade a quem as possue, a arvore do păo, por exemplo, as differentes especies de cana de assucar, que năo temos, etc. etc.

Caso porém se houvesse de : tentar algum novo projecto, ou nova ordem de cousas, para melhorar a cultura deste paiz, eu lembrára fazer o mesmo que se fez em I 692 em. Inglaterra, quando se estabeleceo o Imposto Territorial. Procedeo-se a huma avaliaçăo geral, e exacta do rendimento de todas as terras naquelle tempo, que ainda hoje serve de base ao Imposto que se estabelece sobre a terra; e quando este se fixa agora a hum quarto, ou a hum quinto do rendimento das Terras, isto he, quando se accrescenta o Imposto, nảo, se percebe hum quarto, ou hum quinto do rendimento actual, mas hum quarto, ou hum quinto do rendimento avaliado em I 692 .

Por meios quasi semelhantes, pôde o Grande Fre-: derico fazer dos areass, e charnecas da Prussia jardins continuados.

He tudo, Senhores, que eu posso responder á sua tăo obrigante carta: confesso-lhes que thes disse com ingenuidade de amigo tudo quanto entendia, para aproveitarmos as paternaes aberturas do nosso Augustissimo Soberano. Ficarei muito vaidoso, se thes prestar para alguma cousa a minha resposta, de que lhes dou. 


\section{(98)}

a liberdade de fazer o que bem thes parecer para utilidade deste Paiz: e se forem precisos novos additamentos', ou explicaçóes ao que avanço, aqui me acho prompto para os satisfazer como puder.

Deos guarde a VV. SS. muitos annos.

Engenho da Ponta Maio de 1807.

\section{F. da C.}

\section{CARTA III.}

Satisfazendo á proposta, que me foi presente por determinaçăo dos Senhores Presidente, e Vereadores da Camara desta Cidade, respondo:

Ao r. Quesito: Que entre todos os productos da Layoura deste Paiz he o tabaco o que soffre maior oppressăo, empate, e desarranjo, por serem os conductores obrigados a leva-lo a huma casa de arrecadaçáo, que pela sua estreiteza nẩo pode alojar toda a sua quantidade; de que procede estarem demoradas por muitos dias, e mezes as embarcaçóes que o transportảo, sem poderem fazer descarga, esperando vêr expostas ao Sol, e ás chuvas, que pelo menos fazem degenerar o tabaco, e diminuir o seu valor, quando de todo o năo arruinăo.

A esse damino se ajunta o outro de pagarem os fretadores das ditas embarcaçóes maiores fretes, á proporçăo dos dias de demora; e já tem succedido perigarem algumas por causa de tempestades no tempo da dilaçăo, o qual damno se tem augmentado depois que a Meza da Inspecçăo aprazou tempo certo, no qual 


\section{(99)}

devem vir as embarcaçóes com os tabacos, a que dá causa a concorrerem quasi todas a hum tempo, ser maior a quantidade, e mais difficil a descarga, e até o Commercio padece empate; porque muitas vezes sahom os navios para Lisboa sem poderem levar os tabacos consignados a Negociante, ou por elles comprados, por năo estarem descarregados, examinados, e aprovados.

Ao $20^{\circ}$ respondo: Que tem sido progressivo o augmento da Lavoura; principalmente das farinhas, que sắo o pảo da terra; e dos legumes, depóis que se concedeo a liberdade de preço, e se extinguírăo as taxas, almotaçarias, e condemnaçóes pelo. Alvará dè 21 de Fevereiro de 1765, mandado observar nesta Cidade por Officio da Secrętaria de Estado dos Negocios do Ultramar, dirigido ao Governador D. Fernando José de Portugal na data de I I de Junlio de I799.

A qual providencia fez cessar a oppressáo, que antes soffriảo os Lavradores com as taxas dos viveres, e por essa causa viviăo em pobreza, e faltavăo os mantimentos, de que a terra padecia penuria; e sería util para maior abundancia, e augmento da Lavoura, que se reservassem os filhos dos Lavradores das recrutas para as tropas de linha, fazendo-os alistar nos Regimentos Milicianos, que os năo obrigáo a desamparar as suas Lavouras.

Ao 3." Quesito nada respondo, por pertencer á classe dos homens do Commercio.

Ao $40^{\circ}$, e $5:^{\circ}$ Quesitos respondo: Que sáo rada uteis para a Lavoura, exgiroldo Commercio os exames, que faz a Meza da Inspecçắo dos tabacos ', assucares, e algodóes', ainda que na sua instituiçảo parecessem uteis, quando a Lei se cumpria na eleiçăo de Inspectores Lavradores, e Negociantes de conhecida probidade, e experiencia, e imparcialidade. E menos 
uteis săo no temipo presente depois que o abuso, e ignorancia tem confundido os ferros de 900 rs. dos asslicares, que sendo segundo a Lei só estabelecidos para us assucares de mel, a que chamăo batidos, hoje săo pela maior parte applicados aos assucares de canas, de maneira que săo hoje raras as caixas de assucar, em que se ponha o ferro de fino, e de redondo, estando aliàs os Fabricantes mais adiantados nas experiencias para fazerem melhores assucares. Sería por tanto mais interessante para a Lavoura remover-se o referido darnno com a extinçăo de taes exames, e deixar-se á convençăo dos Lavradores, e compradores dos generos o exame das suas qualidades, e o seu preço, porque assim se vendem por toda a Europa; e sendo o assucar hum dos viveres, parece que tambem se deve comprehender na ordem d'aquelles, que pela já dita providencia se vendem sem aquellas cautelas.

Outro damno gravissimo soffrem os Lavradores do Continente do Reconcavo desta Cidade, donde vem a maior parte dos assucares, tabacos, farinhas, legumes, e ainda algodóes; e procede o mesmo damno da falta de pontes nos muitos rios, e regatos, que atravessáo as cstradas, os quaes com as chuvas impedem as passagens dos carros, e bestas que conduzem os ditos generos para os portos de mar, como igualmente succede nos pantanaes por falta de estivas, ou calçadas.

Donde resulta perderem os Lavradores muitos bois nas conducçס́es, ou pagarem alugueres muito caros aos carreteiros que alugăo, de sorte que tảo enormes despezas diminuem os lucros, e esfriăo os Lavradores, se a muitos de todo năo desanimáo. As Camaras das Villas do Reconcavo nada cuidảo dos caminhos por mais queixas, e requerimentos que lhes fação os Lavradores, escusando-se com o pretexto de não terem 
dinheiros para obras mais necessarias do que as propinas que se despendem nas mesmas Camaras, que por outra parte só cuidảo em fazerem grandes Paços para os Concelhos, por influencia dos Corregedores das Comarcas para sua aposentadoria, quando văo ás Villas; no que o publico nąa interessa.

Sobre os damnos do Commercio devem responder os Commerciantes, que forem tảo francos como eu em dizer a verdade, e que com melhor experiencia possáo explicar as oppressóes, que soffrem, $\mathrm{c}$ năo săo poucas. Bahia 23 de Maio de 1807 .

\section{José Diogo Gomes Ferrĩo Castello Branco.}

\section{CARTA IV.}

\section{Illustrissimos Senbores Presidente, e mais Senbores do Nobre Senado.}

Satisfazendo á determinaçăo de VV.SS. do modo que me he possivel.

1. Q Que reconheço por oppressắo á Lavoura a carestia, e o excesso de todos os generos, tanto os da primeira necessidade para subsistencia dos individuos empregados no trabalho della, como os absolutamente necessarios para os Engenhos, e suas fabricas, e o abatimento do preço d'aquelles, que fazem a somma consideravel dos rendimentos do Estado, a fortuna dos Lavradores, e a felicidade do Commercio.

2. ${ }^{\circ}$ A Lavoura do assucar, bem como todas as mais, se tem augmentado; mas parece que em comparação do grande numero de Engenhos, que de novo se tem feito, năo be vantajoso o excesso que de mais ha: 
na quantidade das caixas, sendo só bastantes para estas o adiantamento que tem proseguido nos Engenhos.já existentes, e ainda em alguns que se formáräo em terrenos proprios para esta Lavoura. Outros muitos Engenhos, que desgraçadamente com o excesso dos preços sc edificáráo em máos terrenos, tem causado a ruina dos seus proprietarios, e a infelicidade dos que já existiảs, bem cono d'aquelles que se erigírāo em bons terrenos. Elles tem causado huma total destruição nos matos, e difficuldade dos mantimentos, por occuparem os terrenos proprios para estas Lavouras; elles inutilmente consomem grande numero de fabricas, e todos os mais generos relativos ao costeio do assucar, de sorte que os Engenhos de bons terrenos, e capazes de dar interesse, esiando na necessidade desses mesmos effeitos, os vem a comprar por hum excessivo preço.

Os caixóes são hum artigo, que tendo chegado ao auge da carestia, e que jámais deixarảo de subir de preço pela difficuldade, e distancia das madciras, se dảo de graça, engrossando com esta despeza todas quantas se fazem indispensaveis para o laboratorio do assucar; vindo por esta causa as propriedades a figurar mais pelo que dependem, do que pelos interesses, que das mesmas resultảo. A alguns Engenhos a maioria do preço deste genero animou ayultar as suas safras; donde procede que náo tendo matos sufficientes; nảo possảo moer mais ; e outros conseguintemente virảo a năo existir em breve tempo. Os mesmos Engenhos abundantes á proporçăo y!le se trabalhäo seus terrenos diminuem na sua producgảo, ficảo mais distantes os matos, e por isso cresce al despeza, fazendo-se necessarios maior numero de braços; è de fabricas, näo podendo ter interesse vantajoso os seus proprietarios ; e Lavradores, sem que haja maioria. no preço do assucar, ou o. 


\section{(103)}

principal auxilio de Sua Alteza Real, sem o que será certa a diminuiçắo das rendas Reaes neste genero.

A Lavoura do tabaco soffre muitas oppressőes por differente modo; e se para o seu trabalho fosse necessaria a despeza do assucar, certamente nenhum Lavrador se empregaria nella.

Principia o seu vexame, depois da manufactura, e conducção, pela demora nos portos do Reconcavo para a Cidade em dia determinado, na sua estada de mezes para desembarques, estendendo-se este mal até aos donos das embarcaçóes, o excesso do preço de cada hum rolo para o seu transporte por causa da dita demora, da pequena casa de arrecadaçăo, da boa ou má sorte do approvador, ou reprovador, do arbitrio do comprador, do pequeno, ou maior preço, e tudo mais quanto concorre para o mal desta Lavoura.

$O$ algódảo, café, e outros generos livres destes vexames, e despezas, se vendem com mais satisfaçăo de quem os fabríca.

3. O Commercio tendo differentes ramos de negocios, e de especulaçóes, muito mais se augmenta; porque sempre compra, e vende a seu arbitrio, fazendo ao Lavrador abatimento de tudo quanto the he prejudicial, e só sobre este carregăo todos os impostos, carestias, e prejuizos; e quanto aos seus vexames, nada posso responder pela pouca, ou nenhuma prática, que tenho neste artigo.

4. Os exames dos generos de exportação desta Colonia nảo só săo uteis, mas necessarios para beneficio da Agricultura, boa fé do Lavrador; e Conrmerciante; e por isso se fez necessario o estabelecimento do Tribunal da Meza da Inspecçäo. O abuso, com que esta Meza procede, tem motivado hum grande mal á mesma Layoura; porém a sua aboliçăo causaria: 


\section{(104)}

a esta maior damno; pois que tendo sido taxado o ferro de 12 , e I4 para o assucar branco feito da cana, o de 6, e 4 para o mascavado, o de 9, e 5 para o branco, e $m$ do mel, infelizmente săo estes os que tem esta Meza adoptado em notavel prejuizo desta Lavoura.

5. Poucos Lavradores podem na presença do Commerciante disputar a qualidade dos seus generos; outros, remettendo-os a mesmo Commerciante, e este adiantando as suas remessas, năo podem conhecer a differença do genero já năo existente; muitos, que residem em grandes distancias, e com difficuldade de vir á Cidade, năo podem por terceiras pessoas (e talvez ignorantes) tratar da qualidade dos seus effeitos, e menos convencionar o valor da melhoria, ou peioria do assucar; e de commuin estando sujeito o Lavrador ao Commerciante, receberia quanto este lhe arbitrasse, e viria a soffrer hum maior damno do que a differença, que póde causar o abuso, com que a dita Meza qualifica o assucar, e maiores desordens haveria entre o Commerciante, e o Lavrador, que descança no arbitrio da mesma Meza, em quem confia.

Renove-se pois, e inalteravelmente se estabeleça a creaçăo da sobredita Meza; e fazendo-se rigorosamente observar as disposiçóes das Leis, será hum meio mais, proprio para prevenir, e acautelar tantos damnos, que tem supportado a Lavoura em geral.

He quanto posso pelos meus limitados conhecimentos responder a VV. SS., que Deos guarde por muitos annos. Villa de S. Francisco 9 de Julho de I807.

\section{,Foaquim Ignacio de Sequeira Bulcāo.}


Cópia do Decreto de 23 de Fevereiro 1808 , para sé crear buma Cadeira de Economia l'olitica no Rio de Faneiro.

Sendo absolutamente recessario o estudo da sciencia economica na presente conjunciura, em que o Brazil offerece a melhor occasiăo de'se pôrem $\mathrm{em}$ prática muitos dos seus principios, para que os meus vassallos, sendo melhor instruidos nelles, me possäo servir com mais vantagem; e por' me constar que José da Silva Lisboa, Deputado, e Secretario da Meza da Inspecçáo d'Agricultura, e Commercio da Cidade da Bahia, tem dado todas as provas de ser muito habil para o ensino d'aquella sciencia, sem a qual se'caminha ás cégas, e com passos muito lentos, e ás vezes contrarios, nas materias do Governo, the faço Mercê da propriedade, e regencia de huma Cadeira, e Aula Publica, que por este mesmo Decreto sou servido crear no Rio de Janeiro, com o ordenado de 400,000 rs. para a ir exercitar, conservando os ordenados dos dois lugares, que até agora tem occupado na Bahia. As Juntas da Fazenda de huma e outra Capitanía o tenhăo.assim.entendido, e façăo executar. Bahia 23 de Fevereiro de 1808.

\section{Con a Rubrica do Principe Regente N. S.}




\section{IN DEX.}

Noçäo preliminar

Carta da Camara da Babia ao Desembargador Foāo Rodrigues de Brito, convidandoo a prestar os seus sentimentos por escrito sobre os

officio do Governador da Babia com os quesitos propostos

Carta I. em resposia a elles, dirigida ao Senado da Camara

Divisăo das causas oppressivas a Lavoura em 3 classes, a saber: falta de Liberdades, Facilidades, e de Instrucçóes . . . . . . .

Subdivisão da primeira classe em 5 artigos a saber:

Artigo I. Obrigaçăo imposta aos Lavradores de assucar, e Negociantes d'escravatura para cultivarem mandioca contra suas vontades . 3

Probibição de crearem gados nas dez legoas de Beiramár Artigo II. Falta de liberdade para estabelecerem fabricas, lambiques, arinaçies de pescar, e engenbos de assucar sem licencas . . . . . Artigo III. Falta de liberdade para venderem seus fructos no lugar que lbes agradar, e por mäo de quaesquer pessoas . . . . . . . Vexames, que soffrem os Lavradores no celeiro publico Ditos, fóra delle Ditos, no porto . . . . . . . . . 10 


\section{NDEX.}

Ditos, da parte daterra, que soffrem os creadores de gados . . . . . . . . . . . II

Vexames no curral, açougues, etc. . . . . I2 Ditos, que soffrem os Lauradores de tabaco inbibidos de olevar a Europa sem prévia approvaçăo

Ditos, que soffrem os de Porto seguro por causa do estanco do páo.Brazil, e diamantes. . I 8 Artigo IV. Falta de liberdade de venderem seus fructos a quem melbor os paga, como atravessadores, revendedores, commissurios volantes. Monopolio dos Marchantes, resuitante de se limitar o numero delles . . . . . . . . 20 Artigo $V$. Falta de liberdade de venderem os fructos em qualquer tempo, que mais lbes convem: probibição de vir o tabaco para a Cidade antes de 20 de Faneiro . . ... .

Probibiça de venderem fructos antes do tempo prescripto nas posiuras.... . . . . 24

\section{Segunda Classe.}

Das causas provenientes de falta de facilidades, como pontes, barcas, estradas, etc.. . . 25 Falt a de buma rua praticavel para carros, pela qual se possa subir da praia para a Cidade alta, plano para se abrir; e para se aproveitarem as agoas dos.rios das Tripas, e S. Erancisco, e do Dique.

Falta de praças de mercado, de cáes, e de buma caldeira para abrigo dos barcos dus vivandeiros ............ 28 Falt a de uniformidade de pezos, e medidas . 29 $V$ exames a respeito delles, e das balanças ... 30 o 2 


\section{N D EX.}

Falta de buma praça de Commercio . . . 30 Falta de palicia de campo, que augmenta a des-

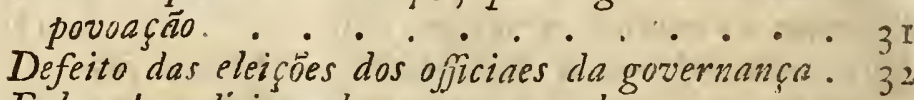
Falta de policia urbana, que tambem augmenta a despovaação, peixe, e carne mal salgados - 33 Cemiterio, pouco aceio, arqueaçōes dos navios, etc. •.. • . . . . • . . 34

Cbinas, e Indios orientaes mais industriosos que os negros, eproprios para diminuir a vadeaçño Votos monasticus fomentão a vadeaçäo, e despovoaçăo

Refórma dos Conventos.

Outras causas de vadeaçăa, escravos de luxo, desprezo do trabalbo mechanico, e muliidão de dias festivos . . . . . . . . : idem. Miendicidade, Recrutamento forçado, meio de au-

gerpetuidade da escravidão, Recolbimento do sexo feminino, falta de bum passeio publico,

o systema de aldear os Indios fóra das povoaçóes . . . . . . . a 40

- monopolio de curar, dado aos Medicos, Cirurgiōes, e Boticarios

A falta de fundos be que principalmente obsta aos progressos da Lavoura

A taxa do juro impede que elles vienbào de fúra., e que. o Lawrador passa baver os que percisa A cruz gravada na moeda fez que nos seculos da superstiçăo se julgasse infamante o juro, - que desvia muitss capitáes da Lavoura. . 44

O. baixo.preço da taxa do juro faz entreter re42 nhidos litigios. idem. 


\section{N D E X.}

Males resultantes do privilegio concedido aos Lavradores, para näo poderem seus crédores arrematar-lhes os Engenbos . . . . . . 45 Falta de bum Registo d'bypothecas •. • 46 As delongas dos processos augmentäo a falta de supprimentos, difficultando aios crédores o reembolso dos seus funcios . . . . . . idem.

O sobredito privilegio tambem prejudica, por embaraçar que os predios passem para miăos babeis

Igualmente as Leis que offendem os direitos da propriedade, assim como as que difficultão as penboras, e arremat açöes, mandando que os crédores sejâo pagos por consignaçōes contra suas vontades

As que lhe mandäo adjidicar bens por menos do

que valem contra sua vontade . . . . idem. As Leis de aposentadorias . . . . . . . 49 As das. inducias que obrigäo o crédior a esperar sem vencimento de juros, nem idonea fiança . • . . . . . . . idem. A nova Lei dos falidos . . . . . . 50 Conservar semelhantes Leis para lesar os estrangeiros be täo injusto, como impolitico . . $5 \mathrm{I}$ Ampliação do privilegio dotal em fraude dos crédores. . . . . . . . . . idem. A Legislaçăo Inglęza, contraria á nossa, favorecendo o cumprimento dos contratos, e a moralidade, segura o credito nacional. A larga duração dos nossos pleitos, que favorece. 52 a estagnaçăo dos capitáes, e augmento do prego dos juros, procede principalmente do systema, emolument ario, pelo gual todos os Officiaes da Fustiça intẹressâo na demora dos pleitos; 


\section{INDEX.}

por isso năo se guardäo as Leis, que os abbreviño

Devia-se iaxar a duraģăo dospleitos, em vez de taxar os preços dos salarios, dos generos, alugueres; e juros . . . . . ... . 54 A injustiça dos julgados fas ertagnar os capitáes 55 Causas della, e meios d'evita-la, reforma dos estudos •. . . . . . . . . 56 Systema dos Furados, applicado aos Desembargadores .. . . . . . . • . 57 Roes de pejados, paladio da nosso antiga liberdade... . . . . . . . . idem.

\section{Terceira Crasse.}

Das causas nocivas i Livoura, provenientes de falia de instrucç̃̃o. Importancia das sciencias para a multiplicaçäo das riquezas . . 59 Dita da economia politica . . . . . . idem. Dita das sciencias fysicas . . . : . . . 6r Melhoramentos no Engenbo da Ponta . . . . 62 Enumeraçăo dos proluctos diversas, que se podiāo aproveitar . . . . . . . . idem. Instituiços que nos faltão para elles se aproveitarem

A probibiçño de levar escravos á Europa impede a diquisição das luzes : . . . . . . 64

\section{Segunda Parte do $1 .^{\circ}$ Quesito.}

Dos meios de evitar os obstaculos indicados : : 65 Escolas para todos saberein ler, escrever, e para - estudo da ecoromia politica . . . . 66 Liberdade da Imprensa $\because$........... 67 


\section{N D E X: \\ Segundo Quesito:}

Leis favoraveis a liberdade de Commercio, primeira causa do augmento da Lavoura . . 68 Falta de execugaño das Leis contrarias á mesma liberdade, segunda causa . . . . . . idem. Situaçño do terreno cortado de rios, terceira causa 69 $E$ capities estrangeiros em mercadorias fiadas a longos prazos, quarta causa . . . . idem. Todas estas causas tem feito adiantar a Larou-.. 3. ra, apezar dos. máos. regulamentos . . . idem.

\section{Terceiro Quesito.}

Os encangos do Commercio recabem sobre o producior, e consumador, salvo as probibiçóes . . 70 Enumeraçăo dos ditos encargos, muito mais pezados que os dos estrangeiros . . . . $7 \mathrm{I}$

\section{Quakto Quesito.}

As qualificaçóes da Meza da Inspecçăo não săo prejudiciaes
Razoes disso

Quinto Quesito. 75

Que as taxas no preço dos generos săo infaustas a Lavoura

\section{Carta Segunda.} 78

Que as Leis, Regimentor, Bandos, e Posturas, säo contrarios a Lazoura..........79 


\section{N D E X.}

Que ja ba dois seculos era sensivel a falta de lenbas, e madeiras . . . . . . . . . Que são sempre illudidas as Leis que resiringem a liberdade dos proprietarios. Prava-se com argumentos, e autboridade de F. B. Say que a intervenção do Grverno nos exames dos generos be inutil, e nociva, desde que se estende a mais do que segurar a verdade das - marcas posias nos generos . . . • . 8 I Abusos do celeiro publico acerca do Commercio

Odas farinbas
zem fom farinbas, afasta os vivandeiros que tra-

$E$ os Almotacés impedindo a sabida dellas nas Villas da sua producçâo

Hume das principaes causas da fome tem sempre sido, segundo Simith, o cuidado que se tomou para afugenta-la-... . . . . idem. Meza da Inspecção be contraria ao Commercio, $e$ Lavousra do algodiao, assucar, e tabaco . idem. Refuino-se os argumentos que se costumäo produzir em favor da Meza . . . . . . 91 A Lavoura tem adiantado apezar dos obstacu-. los que libe tem opposio os Regulamentos, sendo para desejar que S. A. R. della se esque-

Que se devem abbreviar os processos, e melbo85 87 88 rar a administraçăo da justiça, para dar mais segurança de propriedade, espalhar as luzes, e introduzir as plantas uteis que nos faltāo, etc.

Carta Terceira.

O tabaca be que saffre maior oppressäo, por năo 


\section{NDEK.}

caber nas casas da arrecadaçăo, e se năo expedir em tempo, vindo por isso a crescerem os fretes . . . . . . . . . . 98

Oue tem crescido a Lavoura das farinbas, e legumes pela aboliçño das almotaçarias . . . 99

Que nada interessão os exames da Meza da Inspeção . . . . . . . . . . idem.

Prejudica a Lavoura a falta de pontes, estivas, e estradas . . . . . . . . . . . IOO

Carta Quarta.

Que a fundaçăo de Engenbos em terras ordinarias prejudica aos outros, encarecendo as madeiras, lenbas, e mantimentos . . . . idem. Vexames do Lavrador de tabaco . . . . 103 Que a Meza da Inspeç̧̄o be util, não obstante os abusos que ella faz da sua autboridade idem. Decreto, que mandou crear buma Cadeira de Economia Politica no Rio de Janeiro . : . 105

Fin do Index. 


\section{nein}

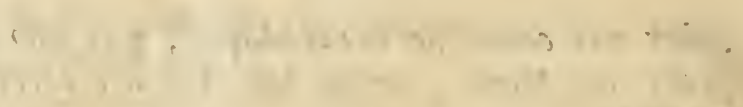

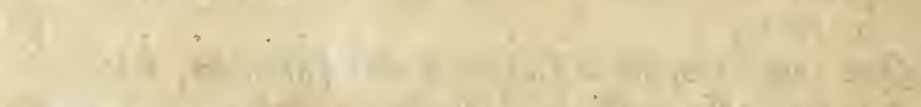

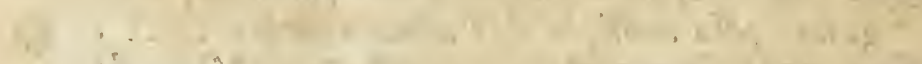

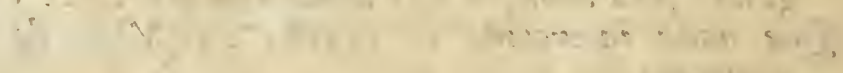

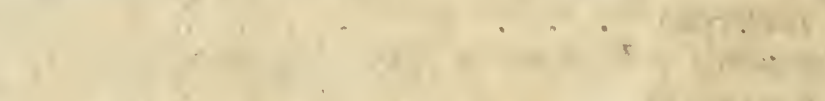

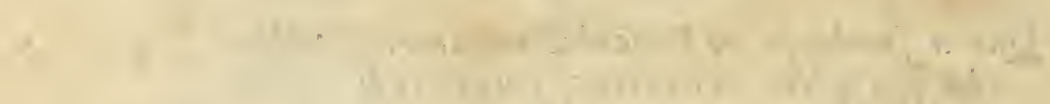

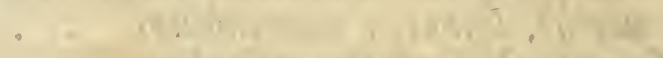

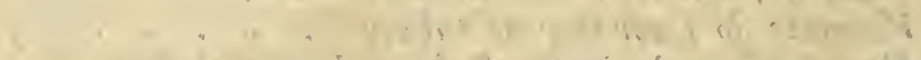

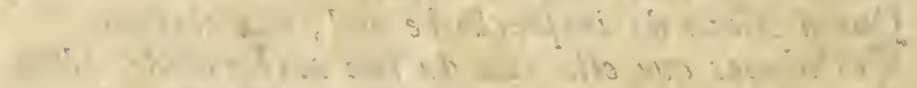

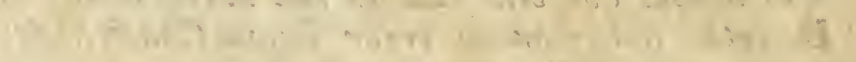

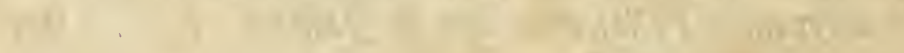
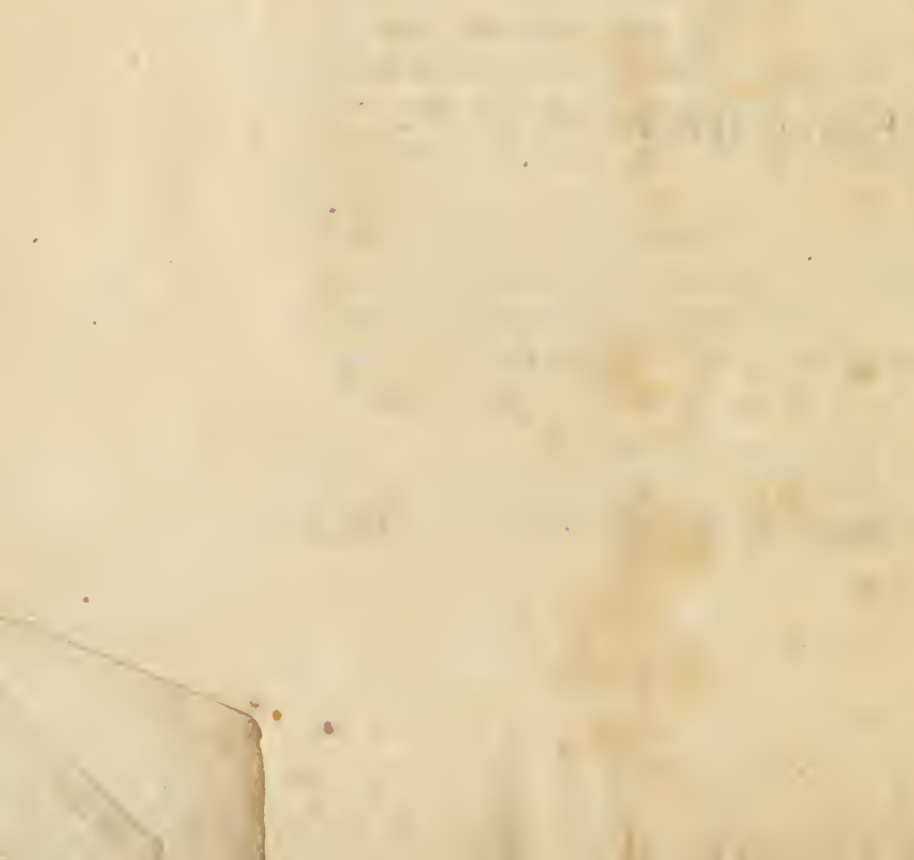


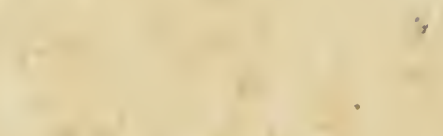

$+$ 




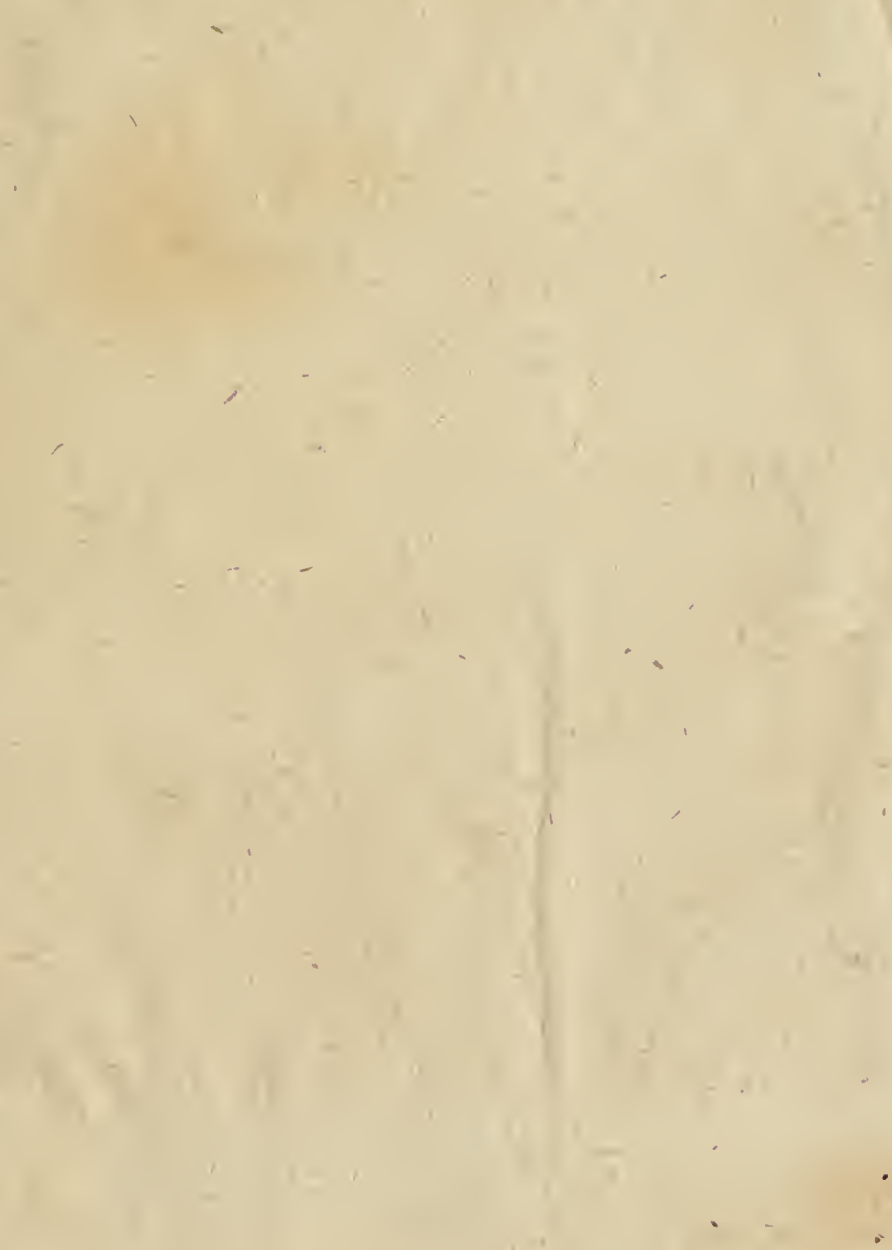
a

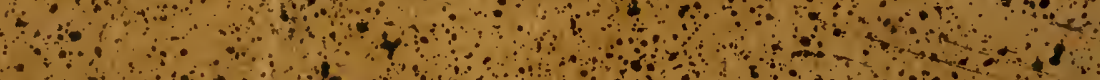

tos

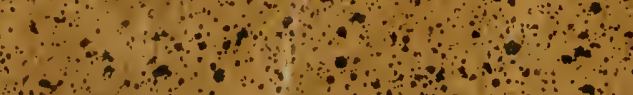

$\therefore$

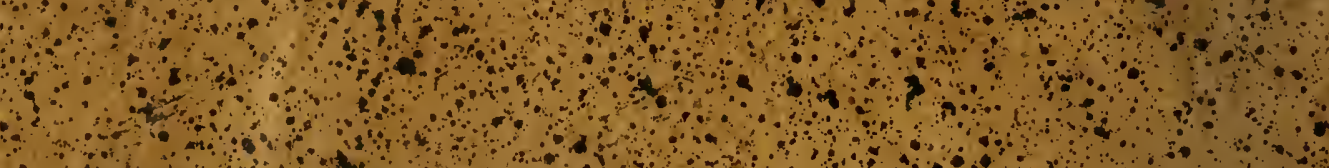

a

$\therefore$ a n (1) a $\therefore$

as

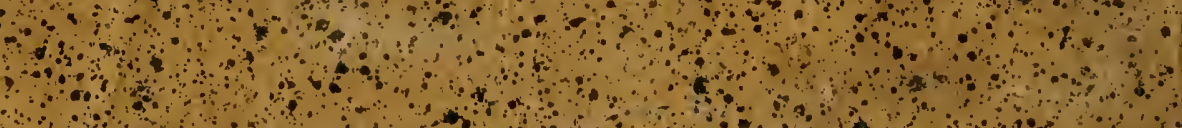
(

(a)

$\because$

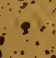

a

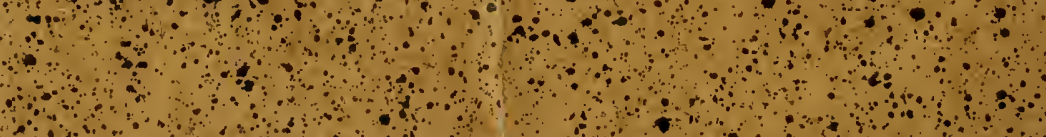

a

( 